Print ISSN 1810-6374; Online ISSN 2618-9844

\title{
All in the Same Boat
}

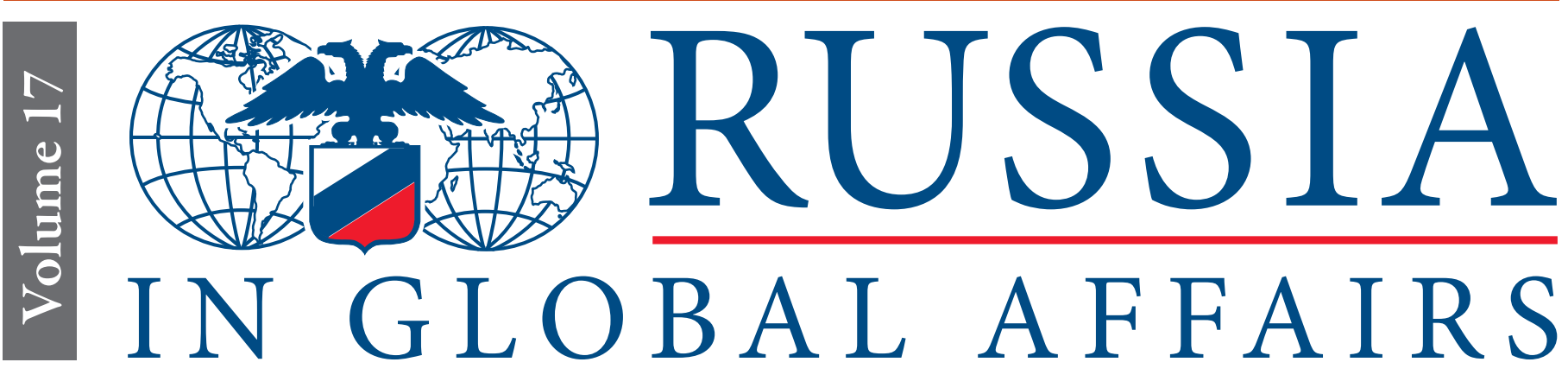

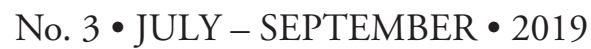

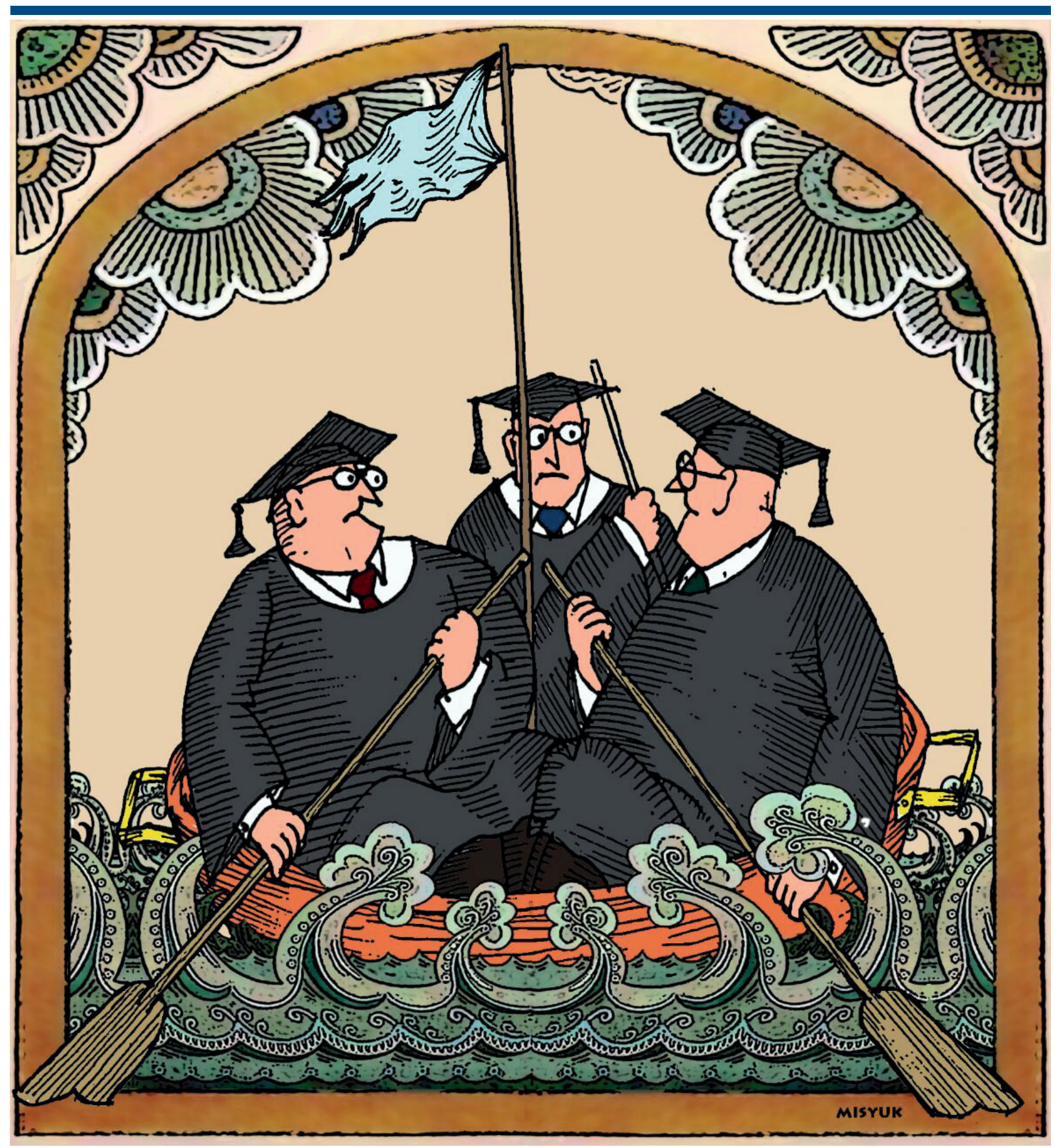




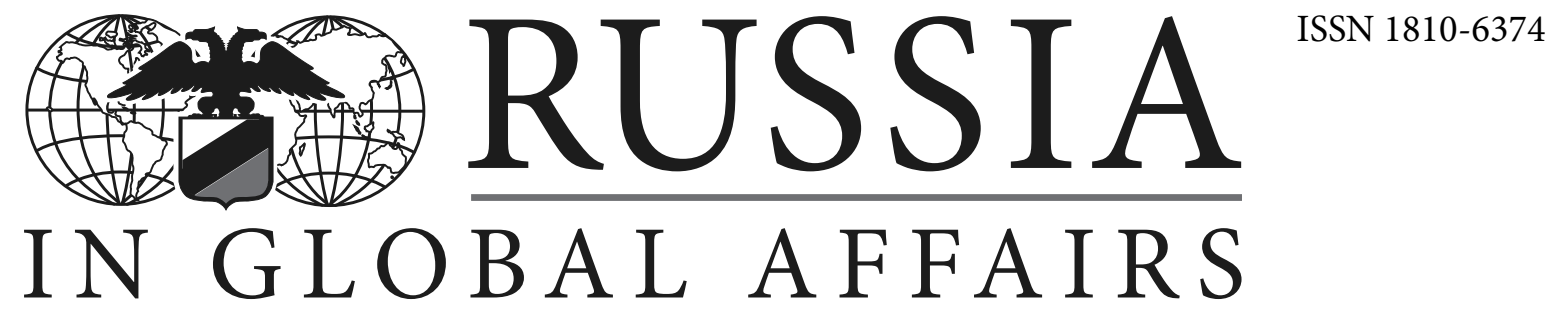

VOLUME 17 • No. 3 • JULY - SEPTEMBER • 2019 
Print ISSN 1810-6374

Online ISSN 2618-9844

BOARD OF TRUSTEES

\author{
Vladimir POTANIN \\ (Chairman) \\ Interros Holding Company \\ Igor ASHURBEILI \\ Chairman, Board \\ of Directors "Socium-A" \\ Ruslan YUNUSOV \\ Director General \\ of Russian Quantum Center
}

FOUNDERS:

\section{COUNCIL ON FOREIGN AND DEFENSE POLICY \\ THE RUSSIAN \\ NEWS \& INFORMATION \\ AGENCY RIA NOVOSTI \\ - RUSSIAN INTERNATIONAL
AFFAIRS COUNCIL}

PUBLISHED BY

FOREIGN POLICY RESEARCH FOUNDATION

17 Malaya Ordynka Str., Moscow 119017, Russia

Address:

17 Malaya Ordynka Str., Moscow 119017, Russia tel.: +7 (495) 980-7353 fax: +7 (495) 937-7611 e-mail: info@globalaffairs.ru http://www.globalaffairs.ru

\begin{tabular}{c}
\hline Registered with \\
THE MINISTRY \\
OF THE RUSSIAN FEDERATION \\
FOR PRESS, TV AND RADIO \\
BROADCASTING AND MEANS \\
OF MASS COMMUNICATION \\
PI No. FS 77-52915 \\
20 February 2013 \\
\hline Printed by \\
Typography "GART" \\
Order No. 1114 \\
Circulation: 500 copies \\
\hline
\end{tabular}

\section{R U S I A I N G L O B A L A F F A I R S \\ Volume 17 • No. 3 • JULY-SEPTEMBER • 2019}

\section{EDITORIAL OFFICE}

Fyodor Lukyanov

Natalya Kostromskaya

Alexander Solovyov

Glenn Diesen

Associate Editor

Irina Palekhova

Administrative Director

Robert Mulcahy,

Alexander Zakharov

Copy Editors

Anatoly Adamishin

Olga Butorina

Alexander Filippov

\section{Leonid Grigoriev}

\section{Sergey Kravets}

\section{Andrey Lankov}

Peter Paul Anatol Lieven

\section{Alexander Lomanov}

Alexei Miller

Yuri Slezkine

\section{Anatoly Vishnevsky}

The views of the authors do not necessarily coincide with the opinions of the Editors. The responsibility for the authenticity and accuracy of the facts in the published articles rests with the authors.

(C) Foreign Policy Research Foundation, 2019

All rights reserved. Reproduction in part or whole is allowed only with the explicit authorization of the publisher.

\section{Editor-in-Chief \\ Deputy Editor-in-Chief \\ Deputy Editor-in-Chief}

\author{
Yevgeniya Prokopchuk \\ Assistant to Editor-in-Chief \\ Vladimir Shabalin \\ Web Editor \\ v.shabalin@itrend.ru \\ Yelena Blinnikova \\ Assistant to Chairman \\ of the Editorial Board
}

\author{
Natalia Zablotskite \\ Computer Makeup \\ Andrei Yevdokimov \\ Circulation \\ op@globalaffairs.ru
}

\section{BOARD OF ADVISORS}

Vice-Minister of Foreign Affairs of USSR (1986-1990), First ViceMinister of Foreign Affairs of Russia (1993-1994), Minister of CIS Affairs for Russia (1997-1998). Moscow, Russia

Dr. Sc. (Economics), Professor. Head of Chair, European Integration Dpt., Advisor to the President, Moscow State University a Foreign Affairs. Moscow, Russia

Doctor of Social Science, Full Professor with National Research University-Higher School of Economics, Head of the Center Humanitarian Historical and Theoretical Studies. Moscow, Russia

Chief advisor to the head of the Analysis Center under the Government of the Russian Federation, Head of the World Economy Chair of the World Economy and International Affairs Department of the National Research University-Higher School of Economics. Moscow, Russia

Executive Editor of The Great Russian Encyclopedia publishers, Chief of the Religious and Research Center Orthodox Encyclopedia. Moscow, Russia

PhD in History, Prof., Kookmin University, College of Social Studies. Seoul, Republic of Korea

Professor, Georgetown University in Qatar, Senior fellow of the New America Foundation in Washington DC. United Kingdom

Dr. Sc. (History). Chief Researcher at the Institute of Far Eastern Studies, Russian Academy of Sciences. Moscow, Russia

Dr. Sc. (History). leading researcher at the Institute of Scientific Information for Social Sciences at the Russian Academy of Sciences, and is a professor at the Central European University in Budapest. St.-Petersburg, Russia

Professor of History, Director of the Institute of Slavic, East European, and Eurasian Studies at the University of California, Berkeley. U.S.A.

Dr. Sc. (Economics), Director of the Institute of Demography of the State University- Higher School of Economics. Moscow, Russia of Fundamental Social Science of the Poletayev Institute of 


\section{EDITORIAL BOARD}

Sergei Karaganov (Chairman)

Martti Ahtisaari

Graham Allison

Alexei Arbatov

Alexander Avdeyev

(in a personal capacity)

Lev Belousov

(Deputy Chairman)

C. Fred Bergsten

Carl Bildt

Vladimir Grigoryev

(in a personal capacity)

Igor Ivanov

Karl Kaiser

Irina Khakamada

Ivan Krastev

Andrei Kokoshin

Mikhail Komissar

Konstantin Kosachev

Yaroslav Kuzminov

Sergei Lavrov

(in a personal capacity)
Dr. Sc. (History), Honorary Chairman,

Presidium of the Council on Foreign

and Defense Policy; Dean of the

Faculty of World Economics and

World Politics of the National

Research University Higher School of

Economics. Moscow, Russia

President of Finland, 1994-2000.

Finland

Douglas Dillon Professor of

Government, John F. Kennedy School

of Government at Harvard University.

Cambridge, Massachusets, U.S.A.

Member of the Russian Academy of Sciences; Director, Center of International Security, Institute of the World Economy and International Relations, Russian Academy of Sciences. Moscow, Russia

Ambassador Extraordinary and Plenipotentiary. Moscow, Russia

Doctor of History, Professor; Head of the Chair of Modern and Contemporary History, Acting Dean of the History Faculty, Moscow University Moscow, Russia

Ph.D. (Economics), Senior fellow and director emeritus, Peterson Institute for International Economics; former Assistant Secretary, Treasury Departmen. Washington, D.C., U.S.A.

Prime Minister of Sweden (1991-1994), Minister of Foreign Affairs of Sweden (2006-2014), CoChair European Council on Foreign Relations. Halmstad, Sweden

Deputy Head of the Federal Agency on Press and Mass Communication of the Russian Federation. Moscow, Russia

Dr. Sc. (History), President, Russian Council on Foreign Relations, Prof., Moscow State Institute of Internationa Relation. Moscow, Russia

Prof., former director, German Council for Foreign Policy; Senior Associate Emeritus, Harvard Kennedy School; Professor emeritus at the University of Bonn. Bonn, Germany

Dr. Sc. (Economics), Politician, lecturer (Moscow State Institute of International Relation), journalist, civic leader. Moscow, Russia

Chairman of the Centre for Liberal Strategies in Sofia, permanent fellow at the IWM (Institute of Human Sciences) in Vienna. Bulgaria

Member of the Russian Academy of Sciences; Director, Institute of International Security. Moscow, Russia

Director General, Interfax News Agency. Moscow, Russia

$\mathrm{PhD}$ (Law); Charmain of International Affairs Committee of the Federation Council (upper chamber of Russian Parliament). Moscow, Russia

Dr. Sc. (Economics), Rector, National Research University-Higher School of Economics. Moscow, Russia

Minister of Foreign Affairs of the

Russian Federation. Moscow, Russia
Vladimir Lukin

Vladimir Mau

Vyacheslav Nikonov

(Deputy Chairman)

Sergei Prikhodko

(in a personal capacity)

Gideon Rose

Kevin Michael Rudd

Vladimir Ryzhkov

Horst Teltschik

Anatoly Torkunov

Yuri Ushakov

(in a personal capacity)

Lord William Wallace

Xiong Guangkai

Igor Yurgens

Sergei Zverev
Dr. Sc. (History), Prof., Ambassador Extraordinary and Plenipotentiary of Russian Federation, member of The Federation Council of the Federal Assembly of Russian Federation; research professor at NRU Higher School of Economics. Moscow, Russia

Chairman of Presidium of the Council on Foreign and Defense Policy; Editor-in-Chief, Russia in Global Affairs, research professor at NRU Higher School of Economics. Moscow, Russia

Dr. Sc. (Economics), Prof., Director, Russian Academy of the National Economy and Public Administration under the President of the Russian Federation. Moscow, Russia

Director, French Institute of International Relations; Member, Academie des Sciences Morales et Politiques, Institut de France; Founder and Chairman of the World Policy Conference (WPC). France

Dr. Sc. (History), Prof., Chairman, Polity Foundation; Chairman, Russky Mir Foundation; Chairman, State Duma Committee on Education; dean, School of Public Administration at Moscow State University. Moscow, Russia

First Deputy Head of the Russian Government Office. Moscow, Russia

Editor-in-Chief of Foreign Affairs; member of the Council on Foreign Relations. U.S.A.

President of Asia Society Policy Institute; Prime Minister of Australia in $2007-2010$, and in 2013

Dr. Sc. (History), prof., NRU Higher School of Economics. Moscow, Russia

Head, Foreign Policy Office of the Chancellor of Germany (1982-1998); headed the Munich Security Conference (1999-2008). RottachEgern, Germany

Member of the Russian Academy of Sciences; Prof., Director, Moscow State Institute of International Relations;

Ambassador Extraordinary and Plenipotentiary. Moscow, Russia

Aide to the Russian President. Moscow, Russia

Prof., London School of Economics; in the past Council Member of the Royal Institute of International Affairs. London, U.K

General (ret.), Adjunct Professor at Qinghua University and Beijing University. China

Ph.D. (Economics), Chairman of the Board of the Institute of Contemporary Development (INSOR); Member of the Board of the Russian Union of Industrialists and Entrepreneurs; President of the All-Russia Insurance Association. Moscow, Russia

President, KROS Public Relations Company; member of the NRU Higher School of Economics's Academic Council. Moscow, Russia 


\section{Contents}

Fyodor A. Lukyanov Everything on Display

\section{RECONFIGURATION}

Richard Sakwa The International System and Models of Global Order 8 Vassily B. Kashin Is the Conflict Inevitable? Not at All.

Timofei V. Bordachev Russia and Europe: Between Integration and Diplomacy

Dmitry V. Yefremenko From Heaven to Earth

\section{WARFARE IN THE 21ST CENTURY}

Ivan N. Timofeev Rethinking Sanctions Efficiency 86

Anastasia B. Likhacheva Unilateral Sanctions in a Multipolar World 109

Konstantin V. Bogdanov Flexible Coalitions: Origins and Prospects 132

\section{OVERCOMING CONFLICTS}

Igor Yu. Okunev Where There's a Will, There's a Way

Alexander G. Aksenyonok Per Aspera ad Pax

\section{INTERVIEW}

Václav Klaus: "The EU in its current form is a tragic mistake of the European history"

\section{REVIEW}

Alexei I. Miller Admonishing the Doubting Flock 


\section{Everything on Display}

Fyodor A. Lukyanov,

Editor-in-Chief, Russia in Global Affairs

Research Professor, Faculty of World Economy and International Affairs, NRU Higher School of Economics

Those who are used to thinking of foreign policy and diplomacy as some sort of ceremonious activity should forget the Congress of Vienna and Helsinki talks. The time of intellectual battles between responsible professionals behind closed doors is gone. Now everything is put on display.

The decline of the basic principles of diplomacy is only one of the signs indicating the degradation of rules and norms which used to underlay international life. "Modern world politics and economy have come to a state of consistent erosion that gnaws at the systems and order developed since the middle of the 17th century. The reason for the general confusion is not that the institutions and rules known to us since the middle of last century (surprisingly, we have become strongly accustomed to them, too) are degrading, but that more fundamental principles of international communication are thrown into doubt." This is a quote from an annual report prepared for a meeting of the Valdai International Discussion Club this fall.

The White House's decision to release the transcript of the telephone conversation the U.S. and Ukrainian presidents held in September 2019, albeit with the former's consent, creates a precedent with far-reaching consequences. The opportunity was immediately seized on both sides of the Atlantic. Zelensky's opponents in Ukraine happily demanded that the transcripts of his telephone conversations with Putin be made public too. Democrats on Capitol Hill are urging their enemy president to do the same...

One can only fanaticize about how such releases can impact not only these countries' contacts with Russia but also foreign policy activities in general. In a sense, we have come to the point where diplomacy as a trade is standing at death's door. There is simply no need for diplomacy if one cannot discuss important things confidentially, discreetly and frankly. Communication turns into an exchange of official statements, a show of strength and subversive operations (if they can still remain covert, of course), but certainly not into a dialogue designed to reach an agreement. Remarkably, this is happening not because of the information revolution or qualitative changes in technology, as many expected, but because of dreadful squabbles and professional degradation that have plagued the political elites in many countries at once and, above all, because of the fierce struggle for power. In other words, the reason is as old as the world itself. It is just that now it has assumed truly cosmic dimensions due to globalization. Current politics has definitively become a tool of domestic policy. 


\section{Fyodor Lukyanov}

Eight years ago, WikiLeaks exposed a large amount of confidential correspondence from U.S. embassies around the world, which contained a lot of details that riled the U.S. and especially its international partners. The Department of State basically pretended that nothing had happened. The leaders and politicians of other countries, hurt by unflattering assessments, took note of it but did not make a row. At first it seemed that the American Foreign Service had suffered irreparable damage and that it would never regain the lost trust. Nothing of the kind! Everything was forgotten within several months. It must be said that the released documents caused not so much an amazement at the disclosed backstage but at how predictable, boring, and often even primitive the secret play was.

But whereas back then it was a leak, now it is a conscious decision. Does the notion of confidentiality, which used to be a key principle in diplomacy, still hold? Those who conduct serious confidential talks must know for sure that their content will never be made public. Otherwise, not only will they fail to achieve the desired result but will make things even worse than they were before. There are fewer and fewer guarantees of confidentiality nowadays.

On the one hand, technologies improve and communication becomes total, increasing the chance of leaks. On the other hand, it becomes customary now to bring to the limelight what used to be behind closed doors. Sometimes one gets the impression that the participants in delicate negotiations fear that their visà-vis will trip them up and for that reason hurry to make the content of their talks public. In part, this is happening because social networks and other modern forms of communication have made the public opinion a more powerful factor in world politics than ever before.

Trump is a vivid example in this respect. His voters' trust and the image of a leader who has nothing to hide from his people are much more important for him than his repute with foreign partners.

The so-called populism is a multifaceted phenomenon, and one of its components is "new sincerity" which can be either real or affected. When he was foreign secretary, Boris Johnson said in parliament that he knew for a fact that the order to poison the Skripals had been given by the president of Russia personally. Let us discount the substantive side of his statement and focus instead on the technical side. The foreign secretary simply could not know such details, it is impossible in principle, especially within just several days of the incident. That idea was never brought up again. But there is an actual fact that the chief British diplomat openly accused the head of a foreign state of perpetrating an assassination attempt, but nothing followed. There were no diplomatic demarches, no investigation, and no demands to explain the statement. Everyone tacitly agreed that Johnson's words were but wind, populist fervor. In other words, idle talk for effect.

But the devaluation of statements has a dual effect. Running off at the mouth has become so widespread that seems almost normal, just a new style-hard words break no bones. Yet no one has abolished diplomacy or other classical forms of state activities so far, and bad-mouthing cannot be simply ignored. Professional trust is crumbling, but confidential channels are needed all the same and seem even to exist. It is just that the entire mosaic will have to be reassembled again at some point. 


\section{Reconfiguration}

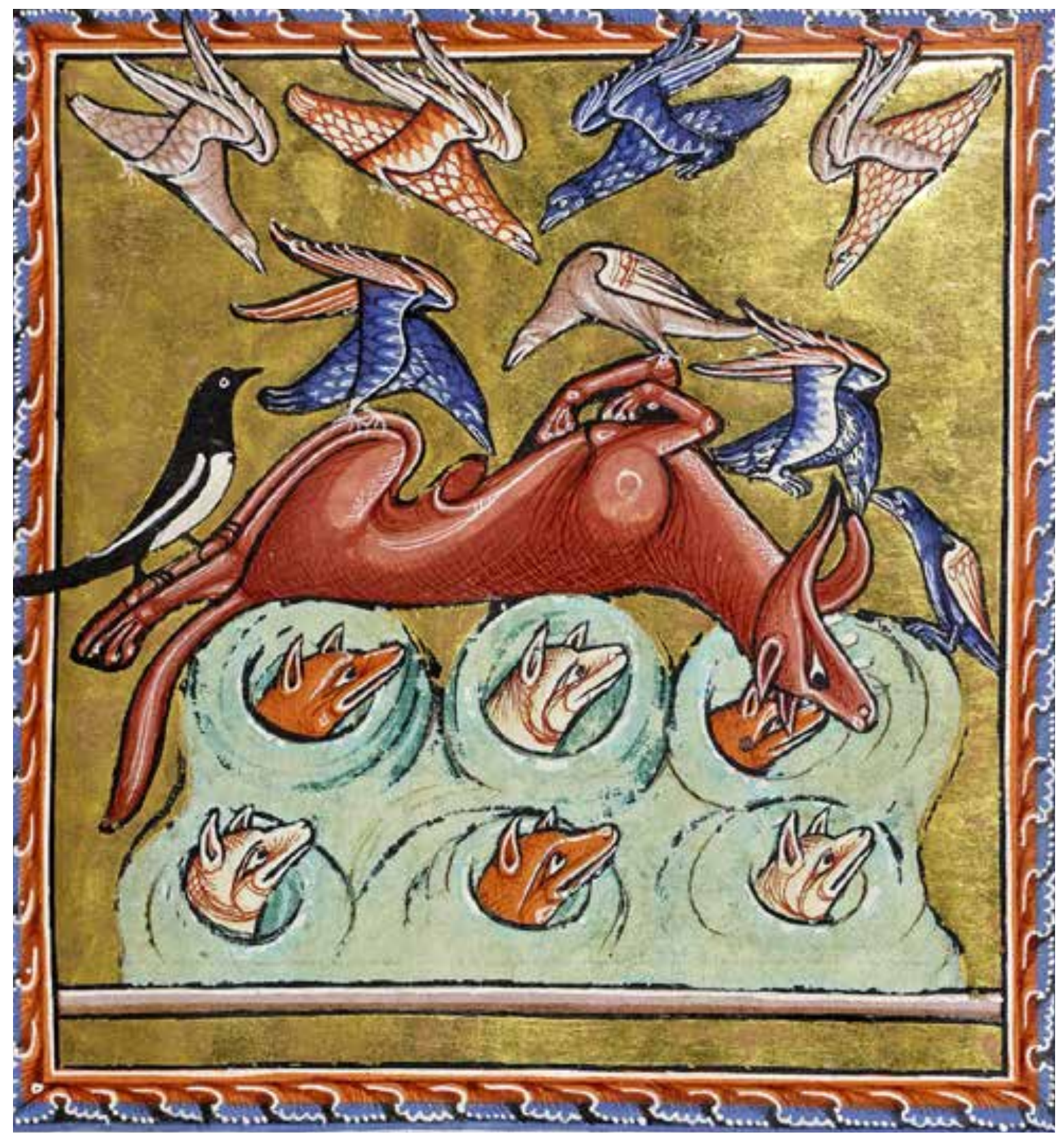

Fox playing dead, bestiary, England ca. 1200 (Aberdeen University Library, MS 24, fol. 16r)

66 The fundamental challenge of international politics today is to move from the post-Cold War monist assertion of one particular model of international order as being synonymous with order itself. 99 


\title{
The International System and Models of Global Order
}

\section{Liberal Internationalism vs Conservative Internationalism}

\author{
Richard Sakwa
}

\begin{abstract}
The international system is presented as a three-story construct, with the international governance institutions at the top, states in the middle, and civil and political society and social movements at the bottom. Within this construct, four types of globalism contend for hegemony today: the liberal international order; transformative (revolutionary) internationalism; mercantilist nationalism; and conservative (or sovereign) internationalism. Each has its own logic, but at various points normative principles and interests intersect with the logic of the
\end{abstract}

\author{
Richard Sakwa \\ MGIMO University, Moscow, Russia \\ Department of Applied International Political Analysis, Associate Professor; \\ Laboratory for Analysis of International Processes, Senior Research Fellow \\ University of Kent, UK \\ Professor of Russian and European Politics \\ ORCID: 0000-0001-6678-8820 \\ ResearcherID: H-3082-2016 \\ Scopus AuthorID: 6506132065 \\ E-mail: R.Sakwa@kent.ac.uk \\ Tel.: 01227 (82)7409 \\ Address: University of Kent, Canterbury, Kent, England, CT2 7NZ
}

DOI: 10.31278/1810-6374-2019-17-3-8-31 
others. This analytical model allows points of contention to be identified, but it also allows for areas of agreement to be recognized. It also suggests that what appears to be an increasingly chaotic international system can be understood to be one in transition from a previously hegemonic structure to a more pluralistic one, in which the normative validity of others can be acknowledged. This opens up the potential for a more open type of international politics, and one which is at the same time more balanced.

Keywords: international system, liberal international order, transformative internationalism, mercantilist nationalism, conservative internationalism

$\mathrm{I}$

nternational politics today is often characterized as chaotic and disorderly, but such a view implies that we have moved away from a more ordered system in an earlier period (Jervis, 2018). This may be the case, but to understand the general trend of international politics today we need to understand the character of the international system. An analytical exercise of this sort can take many different forms, including an overview of the various competing models of the system (realism, liberal internationalism, constructivism and others). This approach is complementary to the works, for example, of Amitav Acharya (2017) and Trine Flockhart (2016). This paper takes a rather different tack and instead examines what could be called the "software" of international politics by identifying four models of globalism, analogous to computer operating systems. By presenting this four-fold analytical model, we thereby introduce the grounds for a more pluralistic understanding of international affairs. Instead of the monism prevalent since the end of the Cold War in 1989, this approach suggests the need for compromise and dialogue between different models of world order. By providing an analytical framework, some of the analytical confusion that besets analysis of contemporary international politics can be obviated. This does not mean that the system thereby becomes any more ordered, but it does mean that thinking can be more systematic. Observers at least have some sort of analytical frame in which policy analysis can take place. 


\section{THE INTERNATIONAL SYSTEM}

Drawing on English School thinking, the international system (the hardware, as it were, of international politics) can be envisaged as a three-level construct (Sakwa, 2017, pp. 38-68). At the top, there is the developing apparatus and processes of global governance (termed 'the secondary institutions' of international society by the English School), with the United Nations at its apex and complemented by an increasingly ramified network of international law and normative expectations. For the English School the primary institutions of international society comprise sovereignty, territoriality, balance of power, war, international law, diplomacy, and nationalism, and these European-generated elements were then expanded to the rest of the world (Bull and Watson, 1984). The so-called secondary institutions include not only the UN but also other bodies that seek to generalize solidarist practices in a plural international system (Buzan, 2014, pp. 3236). They cover the institutions of international financial governance, derived initially from the Bretton Woods system comprising the World Bank and the International Monetary Fund (IMF), and the system of global economic governance, notably the World Trade Organization (WTO). Here also are the international legal and environmental covenants, as well as those covering the rules of war and international humanitarian practices. These secondary institutions are by definition universal, whereas the primary institutions generate practices of exclusion, with the Western core imposing its own "standards of civilization" and acting as the gatekeeper, notably in the context of colonialism Gong, 1984).

Many of the secondary institutions are of Western origin, but their development has been governed from the outset less by expansion than by mutual constitution (this is explored by the various authors in Dunne and Reut-Smith, 2017). For example, the establishment of the UN drew on various Western traditions as well as Soviet, Chinese, Islamic and other ideas. As the secondary institutions strengthen and become more genuinely universal, they threaten accustomed patterns of Western hegemony, but at the same time provide the sinews for order after the waning of this hegemony. English School thinking suggests 
that the international state system evolved out of institutions like the state, territoriality, the balance of power, diplomacy, and sovereignty, which formed in Europe and then expanded through colonialism and then revolutionary nationalism across the world to become truly universal, whereas many of the institutions of international society were created by the Allies during the war and reflected Western values, and were at first relatively exclusive. Without challenging this genealogy, it should be noted that from the first a universalist dynamic was embedded not only in the primary institutions of international society, but also in the top-level secondary institutions, which have since become generalized as the institutions of "global governance" and have become more delineated and gained in authority.

This is where we move to the second level. Beneath the solidarity of international governance institutions we have competing states whose relations in English School thinking are governed by the primary institutions of international society. In the original English School formulation, the international society of states devised in Europe expanded in successive waves to encompass the whole world. This really was an "expansion," enlarging a system into which Russia, with its characteristic ambivalence, was soon incorporated (Neumann, 2011, pp. 463-484). However, the original expansion model is based on a single level system, but with the development of the "secondary institutions" and their associated sharing of sovereignty on functional issues (such as the environment), the single-planed model becomes inadequate.

Hedley Bull's classic study The Anarchical Society (1977/1995) stresses the elements of cooperation and regulation in relations between states, highlighting the way that transnational ideas generate norms and interests that are institutionalized in the form of international organizations and rules. Bull explicitly did not "place major emphasis upon international organizations such as the United Nations," and instead found "the basic causes of such order as exists in world politics" in the "institutions of international society that arose before these international organizations were established" (Bull, 1977/1995, pp. xvii-xviii). Bull's approach retains much of the traditional thinking 


\section{Richard Sakwa}

about a state-centric world, but this is tempered by his view that states have common interests that can be best advanced through the cooperative institutions of international society (For the articulation of a less statist ontology of international society than Hedley Bull's, see Watson, 1992). These are the structures of universalism and interstate cooperation that became increasingly ramified after the Second World War (Anne-Marie Slaughter (2005) and which identify a dense network of "government networks" that increasingly coordinate cross-border cooperation.) It is in this sense that I will use the term 'international society', a broad conceptualization of the institutions of global governance. After the end of the Cold War they were anticipated to gain greater autonomy and substance. Instead, as Cold War bipolarity gave way to unipolarity, they were eclipsed by great power politics and hegemonic practices.

The third level of the international system encompasses a broad range of civil society organizations as well as the media and other forms of societal intervention. Hardline realists typically dismiss the role that international organizations play in international politics, and even more so sub-state movements and processes. However, in the era of neo-liberalism and globalization these can have a substantive impact on global processes. The peace movement of the 1980s failed to prevent the deployment of cruise and Pershing missiles to Europe, but fears of re-awakening the mass anti-nuclear movement are part of the calculation of responses to the end of the Intermediate Nuclear Forces (INF) agreement in 2019. Above all, pressure for drastic decarbonization in the face of the climate catastrophe is now part of the calculus of all rational governments. The upsurge of populist movements and sentiments acts as a warning to the complacency of entrenched elites. Civil society may well take its revenge on the widening inequalities of the neo-liberal era and reshape our thinking about international order.

\section{MODELS OF GLOBAL ORDER}

It is in this context that four types of globalism have shaped international politics in the post-1945 era. By globalism I mean "software" systems 
that provide a consistent set of norms about the correct and most appropriate conduct of international affairs. Globalism is the claim that a particular set of norms and institutions have universal validity. It is not to be confused with globalization, which is a particular technological, communicative, economic and cultural process that cuts across the various models of world order, although populists and other critics tend to confuse the two. The models are not tied to a specific space but to a way of doing international politics and thus represent world "orders." The four models are ideal types, and the practice of international affairs typically draws from a range of repertoires that are not tied to a single one. States can choose elements from the different models, although the character of a regime and its place in international affairs will predispose it to apply one operating system relatively consistently to the exclusion of others.

\section{Liberal international order}

The first is the U.S.-led liberal international order, which was born in the early years of the twentieth century and then formulated by Woodrow Wilson in terms of a commitment to an Atlantic-based system of universal order. The liberal international order is based on an expansive dynamic of universal rules and economic interactions. This has been the most vigorous international order of the modern era, transforming much of the world in its image. The liberal international order combines military, economic and political (normative) sub-orders, each operating according to a specific dynamic but coalescing to create a polymorphic and energetic international order (Chalmers, 2019).

Contrary to much analysis, this order evolves with the changing character of international politics in any particular era. Thus, the postwar liberal international order up to the end of the Cold War in 1989 was shaped by the bipolar confrontation with the Soviet Union and its promotion of an alternative model of world order. The second phase between 1989 and 2014 was characterized by the apparently limitless opportunities opened up by unipolarity. In the absence of a coherent alternative, the liberal international order became radicalized in at least five ways: the Hegelian, associated with the discourse of the "end 


\section{Richard Sakwa}

of history"; the Kantian, with the extreme emphasis on human rights; the Hobbesian, with numerous ill-judged military interventions intended, among other things, to advance democracy in the world; the Hayekian, which represented the triumph of neo-liberal thinking and the disembedding of the market from social relations; and the cultural victory of social liberalism accompanied by the social fragmentation associated with identity politics (Sakwa, 2018, pp. 27-51). Some of this radicalization was the natural result of the absence of a viable competitor, allowing the inherent character of the liberal international order to be developed to its full extent; but some of it was hubristic, exposing a dark exclusivity and intolerance of other social orders and traditional life patterns (Pabst, 2018).

In the third phase, the one in which we now find ourselves, the expansive liberal order met its limits both domestically (in the rise of national populism and a revived leftist internationalism) and in international affairs, in the emergence of coherent alternative models of world order. In part this reflects the broader shift of economic power from the West to the East, but also from the larger failure of the expanding U.S.-led liberal international order to find ways to incorporate the periphery without the former outsiders fearing for the loss of their identity (Zarakol, 2011). In the Russian case resistance in the end took the form of a New Cold War, while in the case of China long-term civilizational contradictions have re-emerged.

Henry Kissinger argues that the vitality of an international order depends on the balance it strikes between legitimacy and power, with both subject to evolution and change. However, he warns: "When that balance is destroyed, restraints disappear, and the field is open to the most expansive claims and most implacable actors; chaos follows until a new system of order is established" (Kissinger, 2014, p. 66). The Versailles settlement in his view placed excessive emphasis on the legitimacy component and the appeal to shared values, and by ignoring the element of power effectively provoked German revisionism (Kissinger, 2014, p. 83). The argument was made earlier, in 1939, by E. H. Carr in his The Twenty Years' Crisis (2001), which in his view prepared the way for renewed conflict. A similar problem exists today 
(Sakwa, 2008, pp. 241-267). In the cold peace years between 1989 and 2014 the stick was bent too far towards the legitimacy (values) side, and then after 2014 the balance within the liberal international order has been increasingly shifting towards the power component, as seen in various sanctions regimes and the return of great power politics.

In the post-Cold War era the liberal international order effectively claimed to be synonymous with order itself. The corollary is that international system as a whole came to be seen as the extension of domestic politics into the international domain. In the post-communist era this gave rise to what can be called 'democratic internationalism' (the term comes from Sokov, 2018). In other words, after 1989 both the power and the legitimacy components of liberal internationalism became radicalized. Exaggerated claims to hegemony undermined its claims to universality and in the end provoked resistance. In our three-storied model of the international system, the institutions of global governance are held effectively to be the property of one of the competing orders. It is this claim to universality that was challenged by proponents of alternative models of globalism.

\section{Transformative (revolutionary) internationalism}

The second type of globalism was represented by the Soviet Union and its allies, which for a time in the 1950s included China. The Soviet Union represented an unstable combination of socialist nationalism and revolutionary internationalism, but with the consolidation of Stalin's rule the former predominated. With the disintegration of the Soviet bloc in 1991, the challenge of revolutionary internationalism largely disappeared. There remain some echoes of the old model in the international system today, and the potential of some sort of revived socialism to transform international politics in the future should not be discounted. At the same time, new sources for the transformational renewal of the international system are emerging, notably the climate emergency. The meaning of revolutionary transformation, of course, in this context has changed from the old Leninist idea of the forcible seizure of power towards the more Gramscian notion of the transformation of social relations, beginning above all in the 


\section{Richard Sakwa}

lower level of our three-story edifice, the arena of civil society and cultural norms. The climate emergency demands new forms of social organization and a thorough rethinking of growth-led models of economic development. Decarbonization will change not only technological but also social relations. Emerging disruptive digital technologies and biotechnologies are already changing the way that people live and work, and we are only at the beginning of this new revolution. In the end, a new form of revolutionary internationalism may be the only answer to the survival of humanity on this planet.

This type of globalism returns to the aspirations voiced by Mikhail Gorbachev and others at the end of the Cold War for a qualitative transformation of international politics. Realists denounce this transformational aspiration as hopelessly idealistic and unrealistic, and they have powerful arguments to support their case (Wohlforth and Zubok, 2017, pp. 405-419). However, the absence of ideational and institutional innovation at the end of the Cold War only perpetuated Cold War practices, which after 2014 re-emerged in full force to divide Europe once again and to roil the world. The prospect of some sort of Greater European partnership was wholly realistic, and in the end probably essential to avoid a renewed bout of Cold War. The failure (so far) of ideas for some sort of European confederation prompted attempts to give institutional form to the political subjectivity of Eurasia and the attempt to delineate some sort of political community for East Asia and Europe in the Greater Eurasia Partnership (GEP) (Diesen, 2017). More broadly, the Non-Aligned Movement (NAM), established in Bandung in 1955, has gained a new vitality to oppose the re-emergence of bloc politics and to give voice to countries overshadowed by the return to great power relations in international affairs. 'Nonalignment 2.0' has been advanced as the keystone of India's foreign policy in the new era (Tellis, et al., 2012).

The transformative role of civil society certainly should not be exaggerated. Although there is growing popular mobilization in response to the climate crisis, including such movements as Extinction Rebellion, their ability to shape politics is as yet relatively limited. More potent by far today are "uncivil society" movements, with so- 
called Islamic State (Daesh) in the vanguard, threatening the very foundations of international society as it has developed over the last half millennium. Nationalist insurgencies continue to threaten states and international order. Violent non-governmental organizations are also developing in the heartlands of capitalist democracy, advancing extreme rightwing identity politics as they portray themselves victims of the alleged liberal hegemony. Anti-immigrant movements are pulling even mainstream parties towards more nativist and exclusivist positions (for a recent study of the challenges, see Krastev, 2017).

At the same time, rampant militarism and unchecked arms spending, accompanied by the breakdown in the strategic arms control regime inherited from the Cold War, is provoking the return of active peace movements. The long-term stagnation in middle class and worker incomes accompanied by the erosion of the physical and social infrastructure in the advanced capitalist democracies has prompted a new wave of leftist radicalism. The question of socialism is once again on the agenda. In short, this transformative model of globalism has deep roots in civil society and is forcing change in states and the institutions of global governance. The precise character of a transformed international politics will emerge from the social struggles themselves, but the key parameters will include new forms of localism embedded in rejuvenated forms of pluralist internationalism. This may well represent a revolution in international affairs as profound as any provoked by world wars and economic crises.

\section{Mercantilist nationalism}

The third type of globalism is gaining increasing traction today. This is the transactional and mercantilist approach adopted by Donald J. Trump and the various national populist movements of our time (Eatwell and Goodwin, 2018). For Trump the international sphere is simply the extension of the market into the larger domain, where a zero-sum logic predominates and in which there is a ruthless battle for market share. The strong become stronger, while the weak endure what they must. There is no room for multilateral agencies or international alliances, which in Trump's view only constrain the United States. 
Values are humbug, everything is transactional, and there is no need for democracy promotion. This is a stark model of unilateral Westphalian internationalism, harking back to an earlier era before 1914 when the first era of globalization came into contradiction with statist Social Darwinism. The national interests of sovereign states predominated, and in part the First World War represented a revolt against the erosion of state sovereignty by market relations. Today, this logic is reprised in the arguments of radical Brexiteers in the UK, and in the sovereigntist movements in continental Europe, notably in Marine Le Pen's National Rally in France, Thierry Baudet's Forum for Democracy in the Netherlands and Matteo Salvini's (Northern) League (La Liga) in Italy.

There is an extensive literature arguing that populism emerges when issues of social concern fail to be addressed by existing elites (Laclau, 2018). This helps explain why Salvini, like Benito Mussolini, moved from left to right. Salvini argues: "Ironically, I see more leftist values in the European right than in some left-wing parties; these parties and these movements are those that today defend workers, those who lead right battles. Thus, I do not see anything strange in looking for a dialogue with whoever today embodies the resistance to this wrong Europe" (Madron, 2013). Russia is presented as the defender of a more conservative and traditional representation of Europe, and thus a strange alignment of Moscow and neo-nativist European nationalpopulists has been forged. Russia thus returned to its nineteenth century manifestation as the defender of conservative cultural values and legitimate government; anti-liberal and authoritarian. This representation is at most only partially accurate, but in conditions of what some call a New Cold War, Russia is certainly looking for friends wherever it can find them, especially if it helps to undermine the unity required for the biannual renewal of European Union (EU) sanctions.

The revolt against globalization is taking place in the very countries that took the lead in outsourcing jobs and services. The benefits have been spectacularly badly managed, and while lifting millions out of poverty in China, globalization destroyed the industrial heartlands of the advanced capitalist democracies while allocating increased wealth 
to the rich. (Technological change has been responsible for the greater part of job restructuring, but "precarity" and other changes in the labor process and social relations of late capitalism come together in conditions of globalization to create a new terrain of social struggle and resistance, much of which is regressive and exclusionary.) This is accompanied by a cultural revulsion against not only globalization but also the apparently heedless cosmopolitanism with which it became associated. This is why the policies advanced by elites in the AngloSaxon world are so readily dismissed, and instead the marginalized masses increasingly look for meaning. (This was supplied by the Trumpian slogan of "Make America great again," and the Brexiteer slogan "Take back control"; they are meaningless but, paradoxically, offer meaning.)

The putative defection of the U.S. from the liberal international order that it had done so much to create was at first welcomed by the Russian elite as a vindication of its conservative stance, but it soon became clear that Trump's mercantilist nationalism has no room for allies or even friends, and that it lacks the intellectual or political resources to challenge the U.S. national security establishment. The Russiagate collusion allegations were in large part fostered by elements in the security agencies, and not surprisingly Trump had a fraught relationship with them. This difficult relationship will endure into the 2020 electoral cycle as the investigations into the Robert Mueller special counsel investigation report their findings. However, despite its unilateralist agenda and critique of traditional Atlantic relations, the Trumpian insurgency overall made peace with what Michael Glennon (2015) calls the "Trumanite state," the vast Cold War military and security apparatus. Despite Trump's calls for an improved relationship with Russia, his policies militated against such an outcome. Russia was once again left out in the cold. It was not alone, and America's European allies faced the unprecedented situation in the post-war era of having to give substance to the idea of "strategic autonomy" (European Union, 2016; Leonard and Shapiro, 2019). Not surprisingly, they talk of chaos in the international system but in fact the crisis is more localized. It reflects the loss of hegemony and strains in the 
liberal international order, and, in particular, in the Atlantic power system. A rogue America threatens to spread this chaos globally.

\section{Conservative (sovereign) internationalism}

The fourth type of globalism is the one now associated with Russia, China and their allies in the Shanghai Cooperation Organization (SCO) and BRICS (Brazil, Russia, India, China, and South Africa). This model of conservative internationalism emphasises sovereign decision-making by nation states, but it also understands the importance of internationalism. This is what distinguishes this model from the mercantile unilateral approach. As in the two-level European Union, the Commission and its agencies exercise elements of supranationalism while the member states retain large areas of inter-governmental autonomy in decision-making, the international system in this sovereign internationalism model operates on the three levels of the international system presented earlier. For conservative internationalists it is the middle floor that is the most important (for Trumpians it is the only one that matters), but this does not preclude a strong normative commitment to the secondary institutions of international society on the top floor, including as we noted earlier the $\mathrm{UN}$ and the whole ramified network of international legal, economic, environmental, and social governance structures.

Although many of these bodies were sponsored by the liberal globalists, exponents of the conservative model of globalism insist that they do not, as it were, belong to them. As far as sovereign internationalists are concerned, drawing in part on the Yalta principles defended by the Soviet Union, they belong to all of humanity. On the middle floor there are the competing states, representing the type of globalism defended by Trump and his ilk, for whom the institutions of global governance are little more than a nuisance. Conservative internationalists tend not to have much time for independent civil society activism, since they emphasize the legitimacy of legally constituted governments, and strongly reject democracy promotion activities sponsored by outside powers. Nevertheless, given the need to pre-empt popular uprisings and "color revolutions," they pay close attention to popular 
moods. For conservative internationalists the main pillar of the international system is strong sovereign nation states.

Sovereign internationalists, nevertheless, recognize the importance of global governance institutions to manage economic and social processes, and increasingly to deal with the climate crisis and digital innovations, notably cyberattacks and information management. Their internationalism is more than instrumental, although defenders of this position are certainly not willing to cede extensive supranational powers to international society. We are still a long way from creating a world government, but there remains a constant dynamic (as in the EU) between the two levels. In other words, contrary to the common claim of liberal internationalists that this model represents a regression to non-cooperative Westphalian statism, in fact this model of world order espouses a non-hegemonic and more traditional form of internationalism. It rejects the democratic internationalism promoted by post-Cold War liberal internationalism, based on the expansionist logic of an order that essentially claims to have ready-made solutions to problems of peace, governance and development. Instead, the emphasis is on diplomacy between sovereign subjects, although this does not preclude commitment to the norms embedded in the institutions of global governance. This approach is also essentially defensive, confronting the U.S. and its interventionist allies to maintain the foundations of the post-Second World War international order. In the Yalta-Potsdam system competing national interests were recognized as legitimate and in this pluralistic environment diplomacy flourished. Even before the end of the Cold War the foundations of that order were being eroded-with the Helsinki Final Act of 1975 both confirming and transcending the old system-and after 1989 more universalistic and normative principles predominated.

It is against this erosion of traditional internationalism, and the accompanying degradation of diplomatic norms, that Russia and China align. However, although they both defend traditional representations of world order, their state interests do not always coincide. When it comes to policies in the UN, the Middle East, Ukraine and some other issues, the two countries often have differing views. The normative 


\section{Richard Sakwa}

convergence is accentuated by the common threat from what is perceived to be liberal revisionism and mercantilist unilateralism, and it is not clear whether policy differences will widen if and when the need for anti-hegemonic alignment becomes less pressing.

In recent years sovereign internationalism has been at the heart of the new regionalism. The Charter of the SCO adopted in June 2001, for example, declared its commitment to the principles of international law represented by the UN and stressed the "mutual respect for sovereignty, independence, territorial independence of states and inviolability of state borders, non-aggression, non-interference in internal affairs, non-use of force or threat of its use in international relations, seeking no unilateral military superiority in adjacent areas" (SCO Charter, 2001). Similar principles are upheld by the BRICS states, and are the bedrock of ASEAN and other regional organizations. The strongest manifestation of this conservative internationalism can be found in the revived RIC (Russia-India-China) triangle, first outlined by the Russian foreign minister of the time, Yevgeny Primakov, in 1996. It is the counterpart of the idea of multipolarity. Chinese commentators stress China's partnership diplomacy, with a network of over 100 partners representing a new type of diplomacy and reflecting China's version of non-alignment. The IBSA (India, Brazil, South Africa) Dialogue Forum formed in 2003 sought to change the balance of power by reforming the UN and reordering the international system, and although its efforts achieved little, the initiative demonstrated that democratic states are as interested in global institutional rebalancing as their more authoritarian counterparts (Hodzi, 2019, pp. 444-456).

Sovereign internationalism is open to four main critiques. First, while the agenda of interventionism may have been used instrumentally and irresponsibly by the Western powers, the necessity of intervention when warranted by grave human rights and other abuses has now been formalized by the UN in the 2005 Responsibility to Protect protocol, which Russia and other conservative internationalist countries have signed (Averre and Davies, 2015, pp. 813-834). Conservative internationalists appear trapped between their commitment to sovereignty and internationalism and have no coherent answer about 
the balance to be drawn between the two in any particular situation. However, the two principles are far from incompatible. China, for example, has been one of the main contributors to UN peacekeeping operations and now positions itself as the defender of globalization.

Second, in a thoughtful defense of the liberal world order, Andrei Kortunov, Director General of the Russian International Affairs Council, argues that it represents the principles of rationality, normativity and openness, and that no alternative can match its dynamism. He insists that "the crisis of political liberalism does not necessarily entail a parallel crisis of the liberal world order" (Kortunov, 2016, pp. 8-19). He proved mistaken in that prediction, and his survey of alternatives (the restoration of empires, the imposition of a single system of values like communism or the global caliphate, or collapse into warring states) failed to examine the whole gamut of other possibilities, as outlined in this paper. Nevertheless, the taint of cynicism and opportunism cannot be easily removed from the sovereign internationalist position. The right to break rules may well be an attribute of a great power, but liberal internationalism at least represented a serious attempt to constrain such behavior.

The third critique is the simplest and yet perhaps the hardest to address, namely that behind the ostensibly attractive notion of a pluralism of systems and orders in the international system, there lurks the simple defense of authoritarian systems. This argument is advanced by the burgeoning literature on the emergence of some sort of "authoritarian international," in which states opposed to the liberal international order align to defend their abuse of power in what has been "authoritarian regionalism" (Libman, and Obydenkova, 2018, pp. 151-165). Many of the criticisms are pertinent, but the loose use of the concept of 'autocracy' and neglect of the power system at the heart of the U.S.-led liberal international order weakens the force of the argument. Conservative internationalism may well turn out to be more pacific and more developmental than its alternatives.

This brings us to the fourth critique, the fundamental question of 'good governance.' The term certainly contains a host of normative assumptions, yet the idea of the rule of law, defensible property rights, 


\section{Richard Sakwa}

informational openness and the adequate defense of human dignity from oppressive authority, are not just the concern of the liberal international order, but too often have been rejected as just another manifestation of Western imperialism. Revolutionary Marxists had earlier thrown out the baby of civil society with the bathwater of capitalist exploitation. Likewise, some of the more particularistic of the sovereign internationalists are also too quick to reject standards of governance when in fact their commitment to internationalism would only be strengthened by recognition of governance problems. In certain international aspects this has been recognized, and the China-led multilateral Asian Infrastructure Investment Bank (AIIB), for example, has adopted rigorous and transparent lending criteria. The rejection of the alleged false universalism propounded by liberal internationalists does not mean that there are no universal values embedded in the top level of the international system. This is not the exclusive reserve of the liberal international order but part of the patrimony of humanity. Implementation everywhere is patchy, but defenders of sovereign internationalism are particularly challenged to live up to their stated commitments.

\section{SOLIDARISM, HEGEMONY AND NEO-REVISIONISM}

The models of globalism outlined above suggest that liberal hegemony is not a necessity for the development of international society or for internationalism more broadly. This framework outlines a model of pluralism in the international system whose key value is pluralism itself. This is a pluralism founded on the belief that each state has to resolve its own challenges, and that historical experience cannot be transplanted from one context to another, the assumption of the democracy promotion activities of the expansive liberal international order. This does not mean that comparative lessons cannot be learned, but it rejects attempts to transfer reified programmatic archetypes. This is the conceptual basis for the rejection of norm transfer as an appropriate framework for relations between states. It does not mean simply the restoration of spheres of influence and the defense of state sovereignty of the Westphalian sort. Instead, resistance to Western 
hegemony is accompanied by the advancement of universal norms by proponents of the transformational and conservative models of global order. In other words, such a scheme not only suggests that there can be order without hegemony, but that there can also be forms of nonhegemonic solidarity.

English School theorists define solidarism as "the disposition either to transcend the states-system with some other mode of association or to develop it beyond the logic of coexistence to one of cooperation on shared projects." By contrast, the sovereign internationalist definition of pluralism is closer to the contrasting English School view of pluralism as "the communitarian disposition towards a state-centric mode of association in which sovereignty and non-intervention serve to contain and sustain cultural and political diversity" (Buzan, 2014, p. 16). Solidarism promotes the benefits of international community, an inherent feature of the rules-based norms of the secondary institutions of international society, while horizontal relations between states are inherently pluralistic, except when combined in various sub-orders. Pluralism is achieved by the recognition of diverse developmental paths and the sovereignty of historical experience that combine to create distinctive security and civilizational complexes, each of which taken together is today conventionally described as a project for world order. (This model in part overlaps with the idea of regional security complexes, in which contiguous states establish a regime of intense security interdependence (Buzan and Waever, 2003)).

This is rather more than the pluralism generated by the realist paradigm, which focuses on great power politics and has little time either for the solidarist elements represented by the shared commitment to international society at the top floor level of global governance, or for the pressures generated by civil society demands on the ground floor. Conservative internationalists stress the pluralism based on the procedures and legal principles enshrined by international society, arguing that this does not require allying with the liberal internationalist order. However, it means that conservative internationalists can autonomously align with the liberal international order and some proponents of revolutionary transformation in defense 


\section{Richard Sakwa}

of the international governance mechanisms, against the destructive impact of the national populists.

What sovereign internationalists reject, however, are definitions of hegemony that limit the autonomy of sovereign powers in the international system. This is where contradictions with Russia and China, as the most consistent defenders of sovereign internationalism, begin. After 1989 it was assumed that the liberal international order was the only remaining viable global order (or operating system in the terminology suggested above). The emergence of alternatives came as a shock to its defenders, and soon drew a response from the radicalized Hobbesian element in that order. The military-industrial component soon rallied behind the Trumpians to confront the challenge. This is why the U.S. National Security Strategy of 2017 warned against the "revisionist powers of China and Russia" (Strategy, 2017, p. 25)

But what does revisionism mean in the current international context? Are Russia and China really out to destroy the foundations of the world order as shaped since 1945? Rather than being fully-fledged revisionist powers, a better term to describe their ambition is 'neorevisionism.' This reflects their dissatisfaction with how international affairs are currently run, but it does not mean that the Kremlin and its allies are out to destroy the international system as presently constituted. The fundamental idea of conservative internationalists is to change the practices rather than the principles of the current international order. The fact of American primacy is accepted, either through exercising "leadership" in the liberal international order, or through "greatness" in the Trumpian mercantilist model. America's overwhelming military and economic predominance is recognized, but this does not mean, as far as Moscow and Beijing are concerned, that all other states have to welcome their diminished role in international affairs. Their fundamental demand is to become accepted co-managers of international affairs. It is on this terrain of sovereign internationalism that the current battle lines are drawn.

The neo-revisionism of Russia and China differs significantly in their practices and the resources that they can devote to the cause. Russia has been forced into a full-frontal challenge, because of the 
perceived intensity of the threat emanating from the enlarging Atlantic system. China had the luxury of a more leisurely adaptation to a period of confrontation, until faced with immediate challenges in the South China Sea, Taiwan and in the trade war initiated by the United States. These differences should not obscure the fact that neither Russia nor China will accept a position of subaltern globalism. They are now united in an anti-hegemonic alignment which has the potential to turn into something deeper and more institutionalized, although both sides for good reasons are hesitant to take this step. The alliance politics before 1914 and the bloc politics before 1989 warn of the inflexibility of alliance systems (a stricture that probably applies to NATO as well).

The idea of neo-revisionism fits into the two countries' view of the international system as a whole. As we have seen in our discussion of the conservative internationalist model of the international system, Russia and China accept the normative order represented by the institutions of international legal, economic and security governance in what we call the "top floor" of the system, above all the UN. Both countries seek certain reforms of these institutions, including the way that the Bretton Woods institutions are constituted and run, but neither is out to destroy them. However, under the threat of sanctions and trade wars, both countries have accelerated the drive to outflank some of these bodies, above all by creating an alternative network of financial institutions. This alternative architecture at present is not destructive to the old institutions, although they may in the end marginalize the order in which they are embedded.

Neo-revisionism in this context means, first, the reassertion of interests, typically couched in the language of sovereignty, and thus repudiates the unmediated universalism of the U.S.-led liberal international order. Both Moscow and Beijing reject the idea that the definition of national interests can be outsourced to an external power, or that concern over the patterns of power and authority in their neighborhoods is somehow illegitimate. Second, the idea that the U.S.-led liberal international order is synonymous with order itself is rejected. This entails an ambitious attempt to universalize 


\section{Richard Sakwa}

universalism. The idea is to free the top-level institutions from their perceived instrumental subordination to the U.S.-led Atlantic power system. Third, on simple empirical grounds Moscow and Beijing point out that this "order" is at best extremely disordered, in part as a result of the radicalization of that order after 1989. Attempts at nationbuilding following regime change have invariably been catastrophic. The hubristic assertion of the power of the Atlantic alliance has been at best misdirected and at worst folly. Russia, in particular, faced by the relentless onward march of NATO to its borders and into the Balkans, believes that beneath the benign carapace of globalization lies an aggressive globalist power system.

Russia is a former superpower that is unlikely to regain its former glory, while China is a re-emerging power that is confident of achieving far more than ever before, but both are neo-revisionist. Does this mean that neo-revisionism is little more than the prelude to full-scale revisionism, or does it suggest that both are ready to accept suboptimal outcomes? Revisionism here means not only challenging the existing balance of power and the structures of the international system, but also the ability to generate norms and to impose rules. To that extent neo-revisionism by definition contains elements of revisionism; but the "neo" element should not be downplayed. It is a revisionism that is tempered by acceptance of power realities and constrained by selfimposed limitations. It is a model of global order that can work with liberal and transformational internationalists, while recognizing that the economic and political sovereignty asserted by the national populists is an attempt to rebalance the stick of globalization that had been pushed too far.

Recognition of four contesting models of globalism is not necessarily a recipe for conflict but provides an analytical framework in which the most vital elements of each can be combined with the principles and the normative drive of others to create new patterns and alignments. Thus, liberal internationalists for example can find common cause with sovereign internationalists in defense of multilateral institutions of global governance, and both in turn can draw on the normative pressure from climate change activists to transform their economic 
practices. Common platforms and cross-order coalitions can create order in a post-hegemonic situation. However, as long as one order claims not only universality but fights to maintain its supremacy, chaos will intensify. The fundamental challenge of international politics today is to move from the post-Cold War monist assertion of one particular model of international order as being synonymous with order itself, because of its assumed privileged relationship with history, to a more pluralistic and dialogical situation in which other models can be recognized as legitimate. An international system in which multiple models compete may be more balanced, ordered and innovative than a hegemonic one, and allow the common challenges facing humanity to be managed more coherently.

\section{References}

Acharya, Amitav, 2017. After Liberal Hegemony: The Advent of a Multiplex World Order. Ethics and International Affairs, 8 September. https://www. ethicsandinternationalaffairs.org/2017/multiplex-world-order/

Averre, Derek and Davies, Lance 2015. Russia, Humanitarian Intervention and the Responsibility to Protect: The Case of Syria. International Affairs, Vol. 91, No. 4, 2015, pp. 813-834.

Bull, Hedley, 1977/1995. The Anarchical Society: A Study of Order in World Politics. Oxford: Oxford University Press.

Bull, H. and Watson, A., 1984. The Expansion of International Society. Oxford: Oxford University Press.

Buzan, Barry, 2014. An Introduction to the English School of International Relations. Cambridge: Polity, pp. 32-36.

Buzan, Barry and Waever, Ole, 2003. Regions and Powers: The Structure of International Security. Cambridge: Cambridge University Press.

Carr, E. H., 2001. The Twenty Years' Crisis, 1919-1939: An Introduction to the Study of International Relations. Reissued with a New Introduction and additional material by Michael Cox. London: Palgrave.

Chalmers, Malcolm, 2019. Which Rules? Why There Is No Single 'Rules-Based International System'. London, Royal United Services Institute, Occasional Paper, April 2019. Available at: https://rusi.org/occasional-papers/WhichRules-Why-There-Is-No-Single-Rules-Based-International-System 


\section{Richard Sakwa}

Diesen, Glenn, 2017. Russia's Geoeconomic Strategy for a Greater Eurasia. London: Routledge.

Dunne, T. and Reut-Smith, Ch. (eds), 2017. The Globalization of International Society. Oxford: Oxford University Press.

Eatwell, R. and Goodwin, M., 2018. National Populism: The Revolt against Liberal Democracy. London: Pelican.

European Union, 2016. Shared Vision: Common Action: A Stronger Europe. A Global Strategy for the European Union's Foreign and Security Policy, June, pp. 4, 9, 19, 45, 46. Available at: http://europa.eu/globalstrategy/en

Flockhart, Trine, 2016. The Coming Multi-Order World. Contemporary Security Policy, Vol. 37, No. 1, pp. 3-30.

Glennon, Michael J., 2015. National Security and Double Government. Oxford: Oxford University Press.

Gong, G. W., 1984. The Standard of "Civilization" in International Society. Oxford: Clarendon Press.

Hodzi, Obert, 2019. "Empty Bravado or Hopeful Illusions": Rising Democratic Powers and Reordering of the International System. International Politics, Vol. 56, No. 4, pp. 444-456.

Jervis, R., Gavin, F.J., Rovner, J. and Labrosse D. N. (eds.), 2018. Chaos in the Liberal Order: The Trump Presidency and International Politics in the TwentyFirst Century. New York: Columbia University Press.

Kissinger, Henry, 2014. World Order: Reflections on the Character of Nations and the Course of History. London: Allen Lane.

Kortunov, Andrei, 2016. The Inevitable, Weird World. Russia in Global Affairs, No. 4, Oct.-Dec. pp. 8-19. Available at: https://eng.globalaffairs.ru/number/ The-Inevitable-Weird-World-18385.

Krastev, Ivan, 2017. After Europe. Philadelphia: University of Pennsylvania Press.

Laclau, Ernesto, 2018. On Populist Reason. London: Verso.

Leonard, M. and Shapiro, J. (eds), 2019. Strategic Sovereignty: How Europe Can Regain the Capacity to Act. London: European Council on Foreign Relations. Available at: https://www.ecfr.eu/page/-/ecfr_strategic_sovereignty.pdf.

Libman, A. and Obydenkova, A., 2018. Understanding Authoritarian Regionalism. Journal of Democracy, Vol. 29, No. 4, October, pp. 151-65. 
Madron, Allessandro, 2013. Lega, il salto di Salvini: Dai Comunisti padani all'amicizia con l'estrema destra. Il Fato Quotidiano, 15 December [online] https://www.ilfattoquotidiano.it/2013/12/15/lega-il-voltafaccia-di-salvinidai-comunisti-padani-allamicizia-con-lestrema-destra-ue/813511/

Neumann, Iver B., 2011. Entry into International Society Reconceptualised: The Case of Russia. Review of International Studies, Vol. 37, No. 2, pp. 463-484. Pabst, Adrian, 2018. Liberal World Order and its Critics: Civilisational States and Cultural Commonwealths. London: Routledge.

Sakwa, Richard, 2008. "New Cold War" or Twenty Years' Crisis?: Russia and International Politics. International Affairs, Vol. 84, No. 2, March, pp. 241-267.

Sakwa, Richard, 2017. Russia against the Rest: The Post-Cold War Crisis of World Order. Cambridge: Cambridge University Press, pp. 38-68.

Sakwa, Richard, 2018. The International System and the Clash of New World Orders. In: Schulze, Peter W. (ed.) Multipolarity: The Promise of Disharmony. Frankfurt/New York: Campus Verlag, pp. 27-51.

SCO Charter, 2001. Charter of the Shanghai Cooperation Organization, 15 June, Article 2.

Slaughter, Anne-Marie, 2005. A New World Order. Princeton: Princeton University Press.

Strategy, 2017. National Security Strategy of the United States, 18 December, p.25. Available at:https://www.whitehouse.gov/wp-content/uploads/2017/12/ NSS-Final-12-18-2017-0905.pdf

Tellis, A., Dhume, S., Fontaine, R. and Scheffer, T., 2012. Nonalignment 2.0: A Foreign and Strategic Policy for India in the Twenty First Century. Carnegie Endowment for International Peace, 12 March. https://carnegieendowment. org/2012/03/12/nonalignment-2.0-foreign-and-strategic-policy-for-indiain-twenty-first-century-event-3587

Watson, Adam, 1992. The Evolution of International Society: A Comparative International Analysis. Reissue with a new introduction by Barry Buzan and Richard Little. London: Routledge.

Wohlforth, W. C. and Zubok, V., 2017. An Abiding Antagonism: Realism, Idealism, and the Mirage of Western-Russian Partnership after the Cold War. International Politics, Vol. 54, No. 4, pp. 405-419.

Zarakol, Ayşe, 2011. After Defeat: How the East Learned to Live with the West. Cambridge: Cambridge University Press. 


\section{Is the Conflict Inevitable? Not at All.}

How Reasonable Are Western Expectations of a Russia-China Confrontation?

Vassily B. Kashin

Russian-Chinese relations in the last 20 years are a story of slow but steady progress. Both Moscow and Beijing have made multiple attempts to radically accelerate this progress, generally ending in failure. That being said, neither the breakdown of individual projects, nor the short-term rapprochement between Russia and the United States after September 11, nor the economic crises of 2009 and 2014 could stop the development of bilateral relations.

With every year, China accounts for an increasingly growing share of Russia's foreign trade. Each year, the two countries move slightly forward in their military and political cooperation. Now China is Russia's second largest trading partner after the European Union. It is also Russia's most trusted partner among major powers in the fields of defense and security.

Starting in the late 1990s, the Western approach to RussianChinese relations was to ignore the significance of this partnership in principle. The relationship was described as a naïve tactical move

Vassily B. Kashin, Ph.D. in Political Science, is a senior research fellow at the Center for Comprehensive European and International Studies at the National Research UniversityHigher School of Economics. He is also a leading research fellow at the Institute of the Russian Far East.

This article is an abridged version of the paper written for the International Valdai Discussion Club. The original version is available at: http://valdaiclub.com/a/highlights/the-west-andrussian-chinese-relations/

DOI: 10.31278/1810-6374-2019-17-3-32-36 
by Moscow and Beijing in the hope of strengthening their positions in dialogue with the United States. Their partnership was said to lack a solid basis, especially economically.

It is now clear that ignoring the nascent Russian-Chinese partnership was not the best strategy for the United States even in the mid-to-late 1990s. While the volume of Russian-Chinese trade was insignificant, Russia during that period helped China make an unprecedented military-industrial breakthrough, leapfrogging one or even two generations in military equipment.

As a result, the early 2010 s saw China's rebirth as a great military power. Recognizing this fact, U.S. military and defense industry planning had to turn predominantly anti-Chinese in orientation. Russian-Chinese defense industry cooperation played an important role in the alignment of forces in Asia and in the world, which was Moscow's greatest contribution to the development of a real multipolar order.

By the 2010s, it was no longer possible to ignore the significance of Russian-Chinese relations. So, denial gave way to recognition of the partnership between Moscow and Beijing as a fact of life, but still nothing to worry about as it would not last long. "I see little in the long term that aligns Russia and China," U.S. Secretary of Defense James Mattis said.

Sooner or later, such factors as "Chinese economic and demographic expansion into Siberia and the Russian Far East," "rivalry in Central Asia" and, finally, the fact that the two neighboring countries "would probably see each other as a threat," especially considering the "burdensome historical legacy of bilateral relations," were expected to lead to conflicts and a collapse of relations.

The threat of China's demographic expansion has never materialized-in fact, the Chinese are leaving their own northeastern provinces for the thriving metropolitan areas in southern China. After the devaluation of the ruble in 2009 and 2014 against the U.S. dollar and the yuan, the idea of mass Chinese migration to Russia became an obvious economic absurdity. The presence of Chinese business in some Russian regions is noticeable, but it does not have dominant positions; Russian authorities' inability to attract Chinese investment is seen as a bigger problem. 
True, there is economic competition in Central Asia, but it is limited, since Russia and China are present in different sectors of local economies: for those countries, China is the main destination for commodities exports, while Russia is the main destination for the export of labor and a source of imports.

The regional countries are more interested in pursuing a careful policy of balancing between major powers, while Russia and China are also trying to keep their competition under control. The so-called historical baggage in bilateral relations is not too heavy either. Since the establishment of relations in the 17th century, Russia and China have fought rarely and sparingly, those conflicts being incomparable in scale with Russia's wars with most of the major European countries or China's conflicts with Japan, the United States or Great Britain. The conflict between the Communist parties of Russia and China in the 1960s-1980s was an unpleasant but relatively short episode in the history of relations.

The last stage of denial about Russia-China relations is the idea of Russia becoming China's "junior partner," forced to follow in the wake of Chinese politics and "play second fiddle." Such a position would sooner or later become unbearable for Russia, which has been a great power throughout its history, and would lead to a collapse of the partnership. All they have to do to bring this about is remind Russia as often as possible that it is a "junior partner" now.

There is one small problem with this approach-it is impossible to justify it. All the evidence sounds naïve and childish and largely irrelevant to the essence of the matter: Chinese GDP is seven times larger than Russia's; China accounts for about 15 percent of Russian foreign trade, and Russia, for less than 2 percent of China's, etc.

But, whenever we talk about alliances, equal or unequal, we are dealing with political, not economic categories. It is more about one side of an unequal alliance having asymmetric leverage over the other's policies. That leverage can result from one of the parties' economic, political, military, or sometimes technological dependence on the other. A large GDP is not the same thing as political weight or influence. You cannot tell others, "Look at our huge GDP! Kneel, you scum!" This will not have the desired effect.

What asymmetric leverage does China have to pressure Russia? From an economic standpoint, this usually means debt. For example, 
debt leverage turned the United States into an influential player in Europe even after the First World War and ensured its dominance after the Second World War. Relying on this leverage, the United States forced its real, rather than imaginary, junior partners in Europe to abandon the fight for their colonial empires.

China does not have any effective debt instruments to pressure Russia, and the Russian government is careful that China does not get any. Russia occupies one of the last places among large economies in terms of its public debt to GDP ratio. Russia's entire external public debt amounted to a modest $\$ 51$ billion as of April 2019, including $\$ 11$ billion in state guarantees for foreign currency loans, and $\$ 38$ billion in Eurobonds. Naturally, this debt structure precludes any serious debt dependence on China. Russia's total external debt lincluding corporate debt) is covered by Russian foreign exchange reserves, and China's share in it is also small. If we talk about the Russian banking sector's liabilities at the beginning of 2019, China accounted for only $\$ 4.5$ billion.

China acted as a major source of loans for Russian state-owned companies during the crisis of 2014-2015, but later on the net inflow of Chinese loans to the Russian economy dropped sharply: Russian businesses began to pay them off faster than they took out new ones. When the ruble fell sharply in December 2014, China offered financial assistance to Russia, but the Russian government declined.

The Russian leadership shows caution with joint projects with China whenever it suspects they might lead to additional strain on the budget or debt to Chinese partners. This is directly evidenced by Russia's participation in China's Belt and Road projects, despite the fact that, politically, Russia supports the Chinese initiative. At the end of March 2019, before attending the Belt and Road summit in China, President Vladimir Putin again decided to postpone the Moscow-Kazan high-speed highway project indefinitely, despite its considerable political importance for bilateral relations.

When analyzing the place that Russia and China occupy in each other's bilateral trade, there is an imbalance arising from the difference in the size of the two economies. But it is hard to think of a way China could use it to blackmail or pressure Russia. Fuel and energy resources dominate Russia's exports to China as well as Russian exports in general-fossil fuels accounted for 73 percent of 
its 2018 supplies. Russia is one of the main suppliers of oil to China, competing for first place with Saudi Arabia.

This does not speak well of the structure of the modern Russian economy. But, from a political standpoint, all prior experience tells us that trade in energy products creates a strong interdependence between supplier and buyer. Unlike other types of goods, any pressure on energy exporters is always associated with immediate and significant losses for the importing country, so it is only used as a last resort in rare cases. The example of Russia-EU relations amid the Ukraine crisis should give major energy exporters confidence.

In the sphere of technology, Russia is still a prominent supplier of military and dual-use products and technologies to China that are important for ensuring national security. Even considering China's much larger supplies of civilian machinery and equipment to Russia, this is a matter of mutual dependence. Russia imports some components for its military equipment from China, but their volume is insignificant, and not comparable with Russian military supplies to China.

Finally, in the sphere of international politics, Russia generally remains a more active and influential player than China. Despite the declared transition to "great power diplomacy," the Chinese foreign policy system remains cumbersome and hardly capable of acting in conditions of risk and rapid change. Russia and China often have coordinated positions on international issues. But in this duo, China plays the leading role only on problems in the immediate vicinity of its own borders, such as the situation around North Korea. Russia's role is usually more significant and active in dealing with international issues in other parts of the world. The situation around Venezuela is indicative: although Russia's economic interests there are far smaller than China's, it plays a much more important political role in the diplomatic process. So, it looks like China is more dependent on cooperation with Russia on international matters than the other way around.

It would be wrong to idealize Russian-Chinese relations. Russia and China have their own points of contention, and there may be ups and downs in their cooperation. But it is clear that their relationship does not fit into artificial concepts based on simplistic ideas about Russia's politics and economy. 


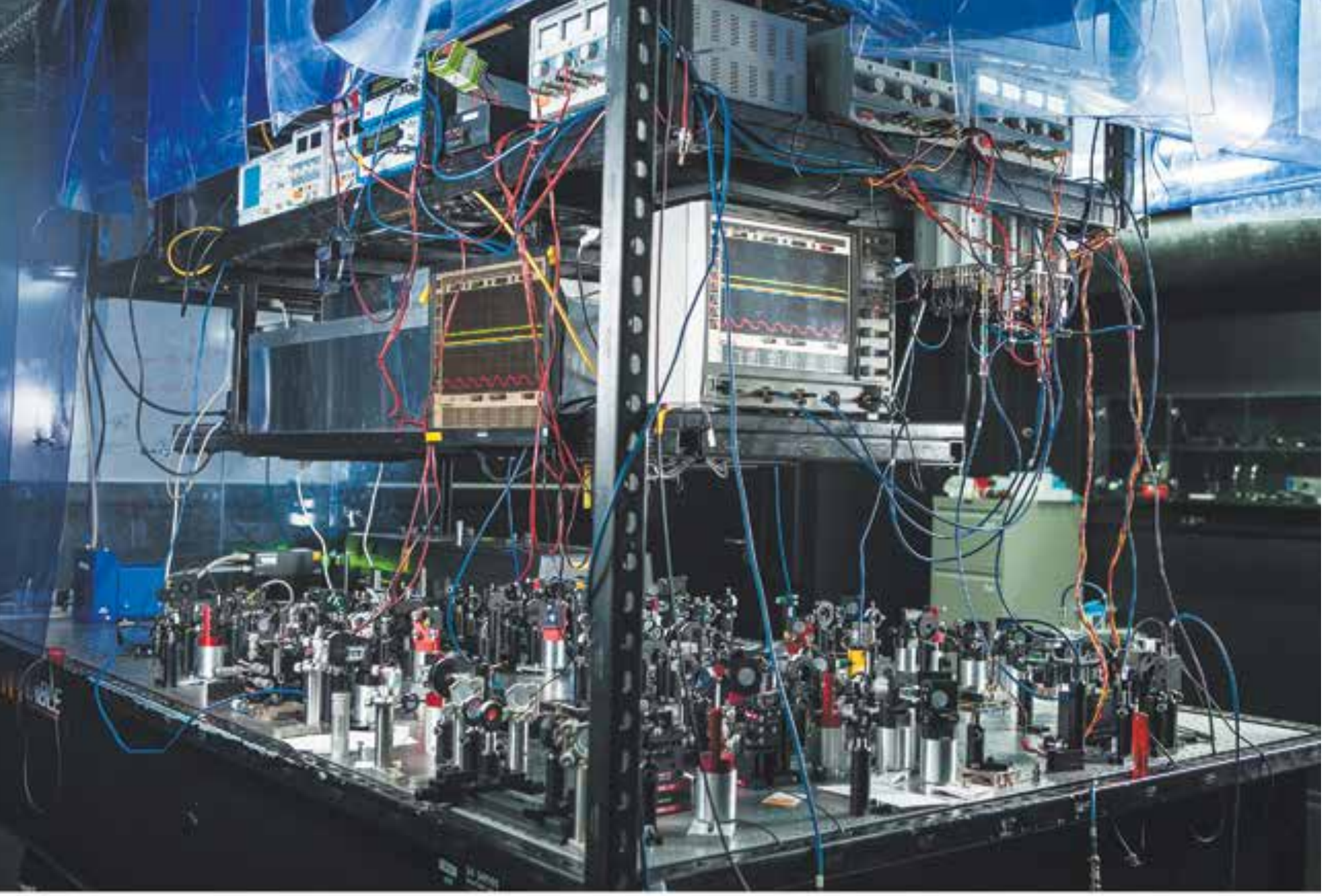

Quantum technologies embodied in microchips and lasers have already changed our world at least once. Now they are about to change it again by controlling matter and light at the level of individual particles. The second quantum revolution will be new materials and ultra-secure communications, superlative accuracy in measurement and efficiency in calculation. The Russian Quantum Center is steadily riding on the crest of this new technological wave.

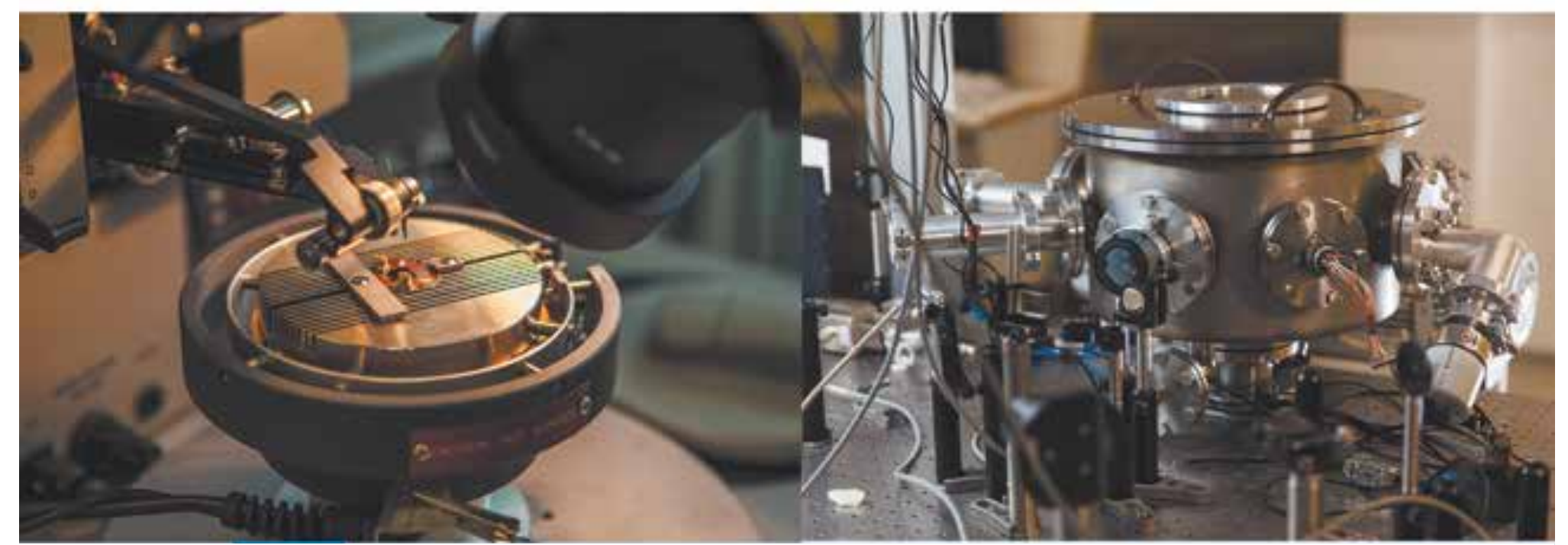




\title{
Russia and Europe: Between Integration and Diplomacy
}

\author{
Is EU-Russia Cooperation a Vital Necessity \\ or a Unique Opportunity?
}

\author{
Timofei V. Bordachev
}

\begin{abstract}
Russia and the European Union had all objective preconditions for establishing a lasting cooperative relationship, which could subsequently lead to integration. However, objective factors of their internal development and systemic changes in global politics resulted in a situation where such relations proved to be unclaimed for both parties. The fundamental cause of the crisis in the relations between Russia and Europe was that for both of them the other party
\end{abstract}

Timofei V. Bordachev, Ph.D. (Political Science)

National Research University-Higher School of Economics (HSE), Moscow, Russia,

Faculty of World Economy and International Affairs,

Associate Professor;

Centre for Comprehensive European and International Studies (CCEIS)

Academic Supervisor

SPIN RSCI: 6872-5326

ORCID: 0000-0003-3267-0335

ResearcherID: E-9365-2014

Scopus AuthorlD: 56322540000

Tel: $+7(495) 772-9590 * 22186$

E-mail: tbordachev@hse.ru

Address: Office 427, Bldg.1, Malaya Ordynka Str. 17, Moscow 119017, Russia

The paper is partly based on the results of the project "Theoretical and Methodological Aspects in the Analysis of the Development of the EU and Transatlantic Relations" done as part of the HSE Program of Fundamental Studies in 2019.

DOI: $10.31278 / 1810-6374-2019-17-3-38-63$ 
was becoming more of an internal negative consolidating factor. In the new historical situation, a return to practices which existed in relations between Russia and Europe before the crisis of 2014 is impossible and, apparently, not viewed as reasonable by either party. However, in the mid-term perspective, the parties may build a new model of relationship based on unbiased assessment of systemic resources and constraints.

Keywords: Russia, the European Union, systemic factors, development, relations, crisis

1 or several centuries, relations between Russia and Europe have been marked by a deep mutual interest and, at the same time, fraught with no less deeply rooted animosity, which sometimes took the form of severe military clashes. However, never in the entire history of their relationship did Russia and Europe have more favorable circumstances for changing this paradigm once and for all than in the last quarter of the 20th century. It was then that objective conditions arose for a rapprochement, not on a metaphysical but on a fully practical and realistic ground, through incorporation of the two parties into a uniform institutionalized system of relations. These conditions, apparent and objective as they were, gave rise to expectations which later proved to be highly overstated.

The failure of this attempt proves the inadequacy of the institutional theory and shows that a larger number of fundamental preconditions should be considered so that the parties could change their behavior, thereby facilitating a transformation of their strategic cultures. Also, consistent internal transformation of Russia and Europe, as well as a change of the international context, may over a longer term bring about conditions in which the factors constraining their integration will cease to be overwhelming. A comprehensive study of all the factors that have a role in the relations between Russia and the EU can significantly improve and enrich the theoretical and methodological toolset of the international cooperation analysis. 
Common experience shows that the more unbridled the initial optimism is, the more apocalyptic sentiments take over if something, everything, or almost everything goes wrong. It is hard to trace a history of international relations similar in scale that would be filled with so many hopes and disappointments as the relations between Russia and Europe. In the second half of the 20th and the beginning of the 21st centuries, it institutionally materialized in the European integration, which in 1991 took the legal form of the European Union. Incidentally, this factor makes it possible to speak of the European Union and use the notion of 'Europe' as an analytical category.

Importantly, the history of relations between Russia and Europe before their contemporary period, which started with Russia's attainment of independence in 1991, was not dramatic, at least in Russia's perception. Intellectual findings of Russian and Western authors are, undoubtedly, of strong historiographic interest to us, but with all the abundance of relevant literature it boils down to a handful of prominent names, such as de Tocqueville, Karamzin, Khomyakov, Danilevsky, Weber, and Iver Neumann (Neumann, 1996).

Today it is much more important to understand and conceptualize what was the root cause of the failure of the rational attempt to achieve an irreversible strategic rapprochement between Russia and Europe in the unique global and internal, for each of the partners, situation which emerged in the wake of the Cold War. It was then that the parties got a unique chance to shape their relations not within the framework of the traditional diplomatic game, artistically framed by philosophers' and men of letters' reasoning about cultural and spiritual kinship or alienation of Russia and Europe, but on the basis of pragmatic cooperation aimed at creating a new international community (Casier, 2013).

The main hypothesis of this study is that for both Russia and the European Union cooperation and potential integration have always been not a vital necessity critical for attaining major goals of development, but an additional opportunity (which they could use or not use, or else use partially). Correspondingly, the gains expected from cooperation were always regarded as relative benefits for either 
party rather than absolute advantages providing equal benefits for all parties and thus constituting a natural systemic factor.

To prove this hypothesis, historical experience of EU-Russia relations since 1991 to this day has been analyzed with due account for objective systemic factors that determined these relations for each of the parties. Thus, the present study is based on a combination of historical and systemic approaches.

\section{PRESUPPOSITIONS AND ASSUMPTIONS}

At the outset of the 1990s, Europe could come up with a legal framework of cooperation with Russia as it had already amassed vast experience in developing relations not on the basis of situational diplomacy, but on the basis of law and comprehensive binding agreements that made clear the rights and obligations of each participant. In the entire human history, European integration was a unique experiment of creating a community of former enemies on the principles of the non-use of force and resolution of disputes solely through legal framework.

The prerequisites for such fundamental cooperation could be easily identified and substantiated, as is evident from numerous works by Russian and, to a lesser degree, Western authors. The most optimistic of them cast Europe and Russia in the role of close relatives, who, even though sometimes differ in opinion, will find a common language anyway (Roberts, 2007). Knit together by common ground and cultural legacy (which cannot be separated), they just cannot do otherwise-that was the overall tone of the reasoning. Yet the correlation of subjective (geographical closeness and commonality of historical experience) and objective (systemic requirements and constraints) factors remained poorly explored.

At one point, maybe a little belatedly, some Russian authors called for the need for Russia and Europe (EU) to develop a common longterm vision of the future (Kononenko, 2009; Baranovsly, and Utkin, 2012). Similar ideas (for example, Gorbachev's concept of a "Common European Home") had been voiced before, but as speculative suggestions only, without the slightest real grounds. Later, in the early 2000s, everybody understood that such a "home" was impossible, 
and even the most optimistic Russian authors went no farther than suggesting a "shared vision of the future" (not a "common future"). However, even such, more pragmatic, suggestions faced the fact that for none of the parties such a vision proved necessary within the framework of Realpolitik and the real goals they set for themselves in that specific historical period.

Common strategic vision suggests the ability to picture an equitable relationship. But for Europe this was impossible from the very start. By the end of the 1990s, the concept of a "Europe of concentric circles" took hold, suggesting that the place of each of the partners was determined by its closeness to the EU (but without membership therein). It should be noted that for many in Russia such model was even desirable, although it was not clear what it should be actually like. In any case, Russia's gigantic scope alone could bring to a deadlock any discussion on how to "embed" its natural greatness in an assemblage of EU states, relatively commeasurable in dimension.

Moreover, neither Russia nor the European Union could really view the interests of the other party as part of its own interests. The reason was their qualitative difference as political players and, correspondingly, difference in goal-setting. Russia has always acted as a relatively homogenous player, able to abstract its internal processes from its interests and behavior on the global stage. For the European Union, foreign contacts were a continuation of its domestic development, even to a greater extent than, for instance, for the U.S. today. The system of the EU's external contacts and interests has always been essentially dependent on the dynamics of European integration and, consequently, could not incorporate the interests of a party (Russia) not involved in the integration process.

In the mid-2000s, these basic contradictions were aggravated by increased difference in ideological and value approaches. Up until the outset of the so-called "wave of right-wing populism" (its advocates achieved biggest success in the elections to the European Parliament in 2019), the dominant values in Russia and Europe were becoming ever more divergent, not to say alien. This divergence was initially noted by European authors (Haukkala, 2009; White and Light, 2005) 
and was later studied in earnest by Russian experts (Romanova, 2016). One can even suppose that as the role of value conservatism in Russia grew, Europe itself was increasingly perceived as a "consolidating Other"-not in Neumann's sense of uniting nations, but in the sense of consolidating a nation consisting of various ethnic and religious groups. Thus, Europe, as an adversary, was becoming an essential part of the ideological construct of the new Russian statehood, a 'state-nation.'

And, finally, the key factor which worked against rapprochement of Russia and the European Union was their completely different vision of the security problem, both at the regional and the national levels. The European Union, from the very moment of its emergence as a relatively autonomous entity of the international system, was rid of serious concerns in terms of traditional security. These problems were efficiently dealt with by the North Atlantic Treaty Organization (NATO) and the U.S. as a "benign hegemon." Therefore, from 1991 to 2014 the discussion on cooperation of EU countries in the security field hinged on the problems of peacekeeping missions beyond the bounds of the EU's immediate periphery.

In pursuing its policy in the East-first of enlargement and then of neighborliness - the European Union took no count of the security dimension, or of what concern its actions could raise with its most prominent neighbor in the region, Russia. One should admit, though, that Russia itself was partly provoking such behavior from the EU. Over an extended period of time, at least from 1994 to 2003, the EU's enlargement was construed by some Russian experts as an alternative to NATO's unwelcome expansion (Danilov and De Spiegeleire, 1998; Póti, 2001, p. 147).

Generally, Russia considered the security issue from the perspective of traditional approaches to ensuring national security and parrying eventual risks and threats. But as soon as it acquired the necessary military and political resources, it firmly stated its position. Thus, the fundamental divergence-an essentially different vision of the regional security agenda-was gradually becoming more and more obvious. The EU and its leading states viewed regional security 
through the prism of extension of their sphere of influence and control by involving new countries in the "EU-centric" system, while Russia saw it from the standpoint of preventing potential threats to national security on the part of alliances and military blocs whose decisionmaking mechanism was beyond its purview.

The critical point in the EU-Russia relations in terms of security was the 2008 Georgia crisis, which had been largely provoked by the discussions over Georgia's and Ukraine's participation in an action plan for preparations to attain NATO membership. As early as 2009, the Russian government came forward with an initiative to hold a dialogue with the European Union on revising and strengthening the European security architecture. Specifically, it suggested reinforcing existing institutions (OSCE) and creating new formats of relations. The 2010 Mesenberg Initiative of Russia and Germany contemplated the possibility of setting up an EU-Russia Committee on Foreign and Security Policy at the ministerial level (Minister of Foreign Affairs S. Lavrov-High Representative C. Ashton). Eventually, the Mesenberg Initiative was swept under the carpet by the EU as unacceptable for a large group of Central and Eastern European states. (It should be noted that there are fundamental studies offering systemic approaches to the periodization of Russia-EU relations (Deak and Kuznetsov, 2019)).

Finally, the European Union responded to the Georgia crisis by just what it should not have done: in 2009 it adopted the "Eastern Partnership" policy directly aimed at tearing away from Russia western post-Soviet states which remained beyond the framework of the EU enlargement (Delcour, 2018). This policy included the signing of Enhanced Partnership Agreements which envisaged-in the optimal version-complete opening of those countries' markets for EU goods and approximation of the regulatory norms, without indicating this as a prerequisite for, or a step towards, their actual accession to the $\mathrm{EU}$, as had been done for candidate countries in the 1990s. In Russia, this initiative was taken as a direct threat to regional stability and security-in the shared neighborhood with the EU-as it posed a serious challenge to former Soviet states. However, the European Union did not pay heed to Russia's rationale. The result was the start of 
the military-diplomatic crisis over Ukraine, which eventually brought the relations between Russia and the EU to their present state.

Not surprisingly, there was no progress towards a rapprochement of the partners' interests and actions, either in form or in content. As a result, in the middle of the current decade there emerged hostility in relations between Russia and leading European countries, which has gradually transformed into an ordered estrangement. At the same time, the necessary diplomatic politesse and economic projects critical for some EU states (like in the energy sphere where the U.S. can do anything but make Europeans give up cooperation with Russia) have been maintained and even invigorated (Tichý and Kratochvíl, 2014; Van der Meulen, 2009; Dimitrova, 2010). Yet there remains a fundamental complex question: Can Europe stop viewing Russia merely as an area of resource development? And if so, why would it do that? Also, can Russia give up looking at Europe as a potential asset within the framework of relations with more powerful players-the U.S. and China, whose magnitude inevitably poses a potential challenge to the very existence of the Russian civilization?

Russia has always been challenged by a complicated internal arrangement of modern Europe, where supranational and interstate elements are combined, with the latter prevailing, (Gehring, Urbanski and Oberthür, 2017). Despite the advanced level and large scale of integration, the European Union remains an association of sovereign states. The difference between them is the extent to which each of them can make its national interest an interest of the community. Therefore, the relations between Russia and Europe in the modern period have in fact become interstate relations, where EU supranational institutions play the role of intermediaries with limited rights (Nitoiu, 2014).

Throughout the entire history of relations between Russia and the European Union, they have been developing under substantial influence of external and internal factors, which have limited the ability of both partners to see these relations as self-important and strategic. The combination of these constraints made the parties unable to overcome the anarchic nature of these relations. Initially conceived as integrative-in nature and content-these relations 
inevitably degenerated into purely diplomatic. Their form and essence were chronically coming into contradiction with each other.

For both Russia and the European Union, cooperation and potential integration have always been not a vital necessity, without which it would be impossible to attain major goals of development, but an additional opportunity (which they could use or not use, or else use partially). Correspondingly, the parties regarded the benefits from cooperation as relative for themselves, rather than absolute, providing equal advantages for all, and thus, serving as a natural systemic factor.

The resulting disharmony generated numerous irritants and eventually made the parties unable to build a dialogue, even when peace and security were put in jeopardy. At present, the relations between Russia and Europe are developing in a basically new context largely determined by the so-called "rise of Asia." The leading Asian powers, above all India and China, are making their way to leading positions in world affairs. Their opinion and strategic culture, which for centuries remained peripheral and seen as optional by the international community, are becoming major factors in the remaking of world politics (Rafiq, 2018; Rössler, 2009).

One of the consequences of these tectonic shifts is the change of U.S. global strategy. What was presented to the world by the Trump administration as an extremal version reflects a profound public aspiration and a no less profound readiness of the American government to respond to it. The internal transformation of Europe and the prospect of a qualitative reform of the entire architecture of European integration are also becoming major factors of change (Lipman and Trenin, 2013). The elections to the European Parliament and an almost all-round success of right-wing forces in Europe indicate that the model created and developed in the previous 30-40 years has reached its limits and has to be changed. We are witnessing a general decline of the institutional component of international relations and an unbalancing of world politics. The structure of the international system is changing and at this point it is not clear what form it will take. The main features of this new structure will apparently depend on the outcome of the systemic U.S.China confrontation which has started in recent years. 
Today it is obvious that the choice between integration and diplomacy in Russia-Europe relations has been made in favor of the latter, that is, in favor of relations aimed at solving current issues and removing immediate threats, without any long-term planning and without a common vision of the future. But is it a tragedy or, at least, a drama from the point of view of the most pressing problems of development that history is setting for both parties? Many analysts, especially in Russia (since Europe is now much more preoccupied with its own problems), speak of mutual detachment or semi-detachment (Lukyanov and Miller, 2017). This is substantiated, above all, by the internal demand for change by each of the parties in the relations under review-a reform of the European integration and final shaping up of Russia as an integral constituent of the international system.

However, one should not forget that external structural factors will be exerting much bigger influence (and even pressure) on Russia and Europe than ever before. Therefore, an important question arises: What may be a third alternative to the ongoing detachment or integration impairing natural interests and possibilities of one of the parties? This alternative must be flexible enough to prevent the main threat of drawing Europe and Russia into a war, while at the same time ensure a gradual increase in the number of factors working towards a situation where the parties would give preference to absolute benefits from cooperation over relative ones.

\section{EVOLUTION OF RUSSIA-EUROPE RELATIONS AFTER 1991}

Of course, the relations between Russia and the European Union did not start from scratch. There had been a short but eventful history of recognition of the European Economic Community by the USSR and its allies during perestroika and the period of "new political thinking." On June 25, 1988, the USSR and the EEC signed a trade and cooperation agreement. Note that the agreement was concluded not between the COMECON and the EEC, but on a bilateral basis. The Soviet leadership did not think of the importance of the multilateral format of relations with the European Union, which theoretically could help extend the life of the Council for Mutual Economic 
Assistance and later facilitate a smoother and equal-right integration of the two European economic associations (Romano, 2014; Mueller, 2011). European associations, on their part, were quite satisfied with Moscow's approach, as dealing with each COMECON member-state enabled them to faster and more efficiently gear up for COMECON disintegration and admit its European member-states to the EEC one by one, and exclusively on the conditions set by Brussels and the leading European capitals (Verny and Vale, 1988). A Cooperation Agreement (an utterly framework one) between the EEC and the COMECON was signed just several months before the demise of the latter in 1989.

Simultaneously, there was more and more active talk about possible formation of a special model of relations on the vast expanse "from the Atlantic to Vladivostok" that would include Europe and Russia. Remarkably, these plans were never given serious expert examination, while literature going beyond political debates is very limited. One can suppose that possibilities for systemic and long-term cooperation between the USSR and the European Communities was from the very start limited, on the one hand, by the uncertain future of the USSR and, on the other hand, by the fact that European integration had entered a period of qualitative reforms, which resulted in the signing in 1991 of the Maastricht Treaty and the materialization of the European Union as we know it today.

The collapse of the USSR, which was followed by several dramatic events practically in all of its former republics, and the EU's simultaneous emergence in a new quality as a semi-economic and semipolitical association were also factors undermining any efforts to establish a systemic dialogue between the parties. The emergence of new independent states in the post-Soviet territory, three of which (Latvia, Lithuania, and Estonia) right away raised the question of accession to the European Union and NATO (in fact, even before gaining actual independence), made any attempts by the EU to establish systemic relations with the government of the collapsing superpower senseless.

At that time the EU was busy assimilating the Soviet legacy and incorporating its parts into a system of "concentric circles," in which Europe would play the role of the natural core. Importantly, it was 
then that a discussion was launched on the possibility of building up a strategic alliance of Russia and Europe. This discussion was incited and sustained mainly by Russia, which is quite understandable. The very meaning of strategic alliance suggested transition to an equitable model of relations, which in no way could fit into any of Europe's two visions of Russia: as an "apprentice" (once again over centuries) or as a "consolidating Other," with the strategic space between them planned to be taken by the EU in the course of its enlargement to the east (Lynch, 2004). An important controversial issue was the hypothetical probability of an alternative to such a course of events. The discussions over the speed and scale of the EU's enlargement to the east continued until the mid-1990s, but the move itself was never put in question.

Historically, Russia and the European Union became participants in international relations simultaneously, amid a radical change of the international system structure in the wake of the Cold War. After the breakup of the Soviet Union international relations entered a new, unique period of relatively incontestable leadership of one power, when the international system structure got most closely to a unipolar order marked by U.S. hegemony and privileged status of U.S. allies in Western Europe. Like any theoretically conceivable unipolar order, the U.S.'s relative hegemony in the 1990-first half of the 2000s did not suggest incorporation in the privileged group of any powers comparable to the hegemon in terms of military capability. In view of this, the participation of Russia in the G8 deserves separate scrutiny.

The new structure of international system was marked by abrupt weakening of the real authority of the UN and other international organizations, the start of debates on their reform, Western countries' desire to lead the decision-making process concerning major problems facing humankind, from intra-state conflicts to climate change, and a relatively weak role of non-Western growing centers of power, above all China. Russia and the European Union treated this international context from essentially different positions.

After the adoption of the Maastricht Treaty, the European Union set the goal of becoming a full-fledged and influential center of power. In the first half of the 1990s, the EU began to actively implement 
such large-scale projects as introduction of the euro in cash and noncash transactions, enlargement to the east and to the Mediterranean, and made attempts, albeit not very successful, to create common mechanisms in foreign and security policies. All these measures were supposed to make Europe able if not to act on equal terms with the U.S. in the world arena then at least to control its own periphery, have a say in global affairs, and even to compete with it in certain spheres, such as challenging the U.S. dollar in financial markets.

Implementation of this challenging task could have been considerably facilitated had Europe been prepared for strategic alliance with Russia. Even in its weakest position at the end of the 1990s, Russia, owing to its immense natural resources and military potential, could have increased Europe's military strategic and economic might several times over. However, this proved to be impossible. Europe continued to perceive Russia as a country too vast and historically alien to be painlessly integrated with an association of small and medium-sized states.

Association with Russia, even conceptually, posed a challenge to the U.S. might and the structure of all Western institutions, the most important of which was NATO (Luňák, 1999). Feverish attempts to make NATO useful after the end of the Cold War gave way to vigorous preparations for its eastward expansion already in the mid-1990s, and, after the events of the spring and summer of 1999 it became completely clear that NATO's main potential adversary in Europe was Russia, if not in the immediate future then in 10-15 years' perspective. Considering the chaos reigning in Russia in the 1990s, any serious talk that some hypothetical association with it could help Europe gain strategic sovereignty looked unfeasible, albeit far-seeing.

Russia was to adapt itself to the new reality and take into consideration the drastic setback in its capabilities. This was taking place at a time when there was no alternative to the West as a source of resources for development programs. The first Chinese initiative of genuinely international scale was put forward only in 2013, that is, twenty years after Russia had to decide on its positioning in the new world and integration in the international community. 
In that historic period Moscow faced a large-scale task of its international rehabilitation and, at the same time, protection of its basic national interests, above all its territorial integrity. The latter problem, or, more precisely, its consequence as the First Chechen war of 19941996, was one of the reasons for the delay in the ratification by the European Union of the 1994 Partnership and Cooperation Agreement between Russia, the EU and its member states. The Agreement came into force only in 1997, when the strategic lines of development of both Russia and Europe had been generally defined (Smith, 2014). Thus, the 1994 Agreement came not as a strategic manifesto but a technical document, and both parties perceived it exactly as such.

As for international rehabilitation of Russia, the priority was accession to the G7 and the WTO, where the U.S. had the decisive vote. Besides, up until the completion of its grand-scale enlargement in the 2000s, the European Union could not offer its partners, including vast Russia, any consistent agenda of cooperation and integration, even in terms of organization (Asmus, 2008). It was suggested that Russia should "work on itself' and make itself closer to European standardswithout any clear prospects of tangible economic (access to markets) or political/moral (rehabilitation as a global player) benefits for itself (unlike EU candidate countries).

In other words, in 1991-2001 Russia and Europe were solving the task of their global positioning on their own, the way they saw them. A closer analysis of these tasks shows that practically none of them required close cooperation or integration of the partners.

Thus, the dual nature of Russia-EU relations up until the beginning of the systemic crisis in 2014 was determined by the fact that none of the partners could perceive strategic rapprochement as an essential means of survival in the long term. The strategic deadlock was brought about by exactly this contradiction between the subjective desire to cooperate and the objective lack of necessity to do so in earnest in order to take into account the spheres of cooperation and the partners' interests while shaping their home and foreign policies. The partnership of Russia and the EU has never been a "partnership of necessity"; it has always remained a "partnership of choice" (Schmidt-Felzmann, 2016). 
Some renowned Russian political scientists even tried to apply to Russia the approach of the so-called "English School" in the IR theory, maintaining that the country stood a good chance of becoming part of the "international community," that is, the West (Trenin, 2002). Other scholars thought that the West should accept Russia as it was, and in so doing become stronger itself. None of these viewpoints took the upper hand. So, it looks inappropriate now to attribute the gradual deterioration of Russia-EU relations to the state of crisis just to the missteps made by the West. The reasons for such outcome are much more profound.

The question of how indicative the tactics of "joining Europe" was of Russia's strategic choice in favor of European integration "on any terms" (as was the case with Central and Eastern European countries) remains open. No doubt, during the darkest period of Russian history, in the decade of 1991-2001, only Europe could serve as a source of investment, technologies and development programs for Russia. However, the significance of the European Union for the country's strategic survival was next to none and, consequently, Russia was not ready to take European recipes in earnest.

The European integration project entered the 1990s with a completely different "baggage." The collapse of the socialist system in Eastern Europe was perceived not only as a challenge (the need to take in a multitude of Eastern Europeans), but also as an opportunity (the emergence of an unprecedented expanse of resource development), especially with regard to the human capital, which was historically, culturally, and religiously akin as no other would be. The formation of a united Europe, with its gigantic market and population of about 500 million, made it incontestably second in the world hierarchy. But incorporation of Russia into such a system on European terms was impossible. Moreover, Europe did not need it. With a population of half a billion, Europe did not need Russia in order to survive in the then calm global environment.

At most, one could expect Russia to slowly move towards a model similar to that of Ukraine and other countries of "Eastern neighborhood," a territory of unhurried resource development. Therefore, all negotiations on a new strategic Agreement, which Russia 
and Europe were engaged in starting from 2005, were based on the assumption that there was no strategic prospect, even a long-term one, of building an integral whole based on the two international entities. The most far-seeing observers aptly noted, however, that such a whole could in the long run become an international player comparable to China and the U.S. (Rössler, 2009).

Furthermore, both Russia and the EU, besides lacking strategic need in each other, soon got real alternatives. In fact, Europe already had such an alternative in the face of the U.S. As soon as the global financial crisis broke out, it became clear that Europeans would not hold out without the support from Washington and financial institutions controlled by it. Russia received a convincing alternative in terms of tactically needed resources and technologies from rising China. Nonetheless, like in the case of Europe, China did not and, apparently, will not become a partner without which Russia will not be able to survive.

In principle, the problem of existence or non-existence of an alternative is typical of any close cooperation between sovereign states. An ideal case is the European integration. ASEAN, MERCUSOR, and integration associations in the post-Soviet space are less spectacular examples. In all these cases, participation in an association does not provide the member countries with "absolute" benefits from integration, which in the long term are more important than any losses or acquisitions.

Russia and Europe will have to address, side by side, or even together, many challenges which the 21st century has in store for them. Europe has failed, and will hardly be able, to create a politically integrated space capable of acting unitedly in the global arena. Russia will remain a country which can ensure its sovereignty and survival on its own, without support from allies. The crisis that started in the relations between Russia and Europe five years ago was largely the result of their insufficiently sound approach to the future of their bilateral relations. Today the EU and Russia continue to act within the same old paradigm, although it has outlived its usefulness. However, in the years to come Russian and European intellectuals will have a unique opportunity to 
look at the bilateral relations without reservation and discuss what these relations must be like in order to survive the troubled 21st-century world, in which we do not need each other too much.

This discussion must primarily focus on the attitude of Russia and Europe towards major regional security institutions and, in a lesser degree, development institutions. For Russia, the central issue concerning these institutions is their role as consolidated and inclusive associations, where the voice of Moscow will be heeded and be able to influence the pan-European agenda. Besides, Russia views institutions like the OSCE as a possible alternative to NATO and, later possibly, to the European Union. Last but not least, there remain strategic global concerns of Russia as the legal successor of the USSR (Larrabee, 2003).

The European Union, on its part, has been regarding the pan-European institutions from the perspective of acting more independently in addressing regional and global matters and, which is no less important, in strengthening the unanimity within the union on issues of foreign policy and security strategy. For the European Union, such institutions as the Council of Europe or the OSCE have always been important not per se, but as instruments of promoting its foreign-policy agenda. It is not accidental that in all known schemes of organization of the pan-European space both these entities have always been presented and positioned only in reference to their closeness and connection to the core, the European Union. Importantly, all EU countries must act in the Council of Europe or the OSCE from a uniform, pre-agreed position.

As a result, Russia acted in the Council of Europe and the OSCE as an individual country, while the EU did so as a disciplined bloc, which predetermined the basic difference in their approaches, strategies, and tactics. This particular circumstance made contradictions between the two parties inevitable and gradually proved ruinous for the capacity of the OSCE and the European Council. Little by little, both these institutions have turned into a kind of "battlefield" for Russia's and Europe's diplomacy, which as early as the second half of the 2000s largely thwarted their activity (Smith, 2014). However, this did not rule out the parties' consent on individual tactical or technical issues. 
Overtheperiod of 1991-2008, relations between Russiaand theEuropean Union went through the stages of enthusiasm, disappointment, new enthusiasm, and eventually, at the end of the 2000s, plunged into stagnation (Casier, 2016). The last attempt to revitalize them was the so-called "Partnership for Modernization" initiative which the parties put forward in 2009. This initiative was the EU's response to the debates over the necessity to modernize the Russian economy and society, which gained momentum under President Medvedev, and suggested substantial support from the European Union to any modernization initiatives of the Russian government. However, this initiative proved dead-born, as it immediately bumped into the partners' different visions of modernization as such. For Russia, the question was, above all, renovation of the scientific and technological base of its economy, whereas for Europe the case was reorganization of Russian institutions and of its entire sociopolitical system.

An additional irritant was the considerable number of new representatives in the European Commission from Central and Eastern European countries which had just joined the EU. By the end of the 2010s, the talks on the "Partnership for Modernization" had faded away, and negotiations on a new Russia-EU Strategic Agreement were in fact suspended in December 2010. All discussions on modernization were eventually buried by the crisis which broke out in the eurozone and by the complication of political relations in late 2011-early 2012. In addition, both Russia and the European Union had to address more serious challenges related to global changes.

\section{RUSSIA AND EUROPE FACING EVER NEW CHALLENGES}

The structural transformation of international relations, which started after the U.S. and its allies had failed to build a unipolar world order, posed new challenges to Russia and the European Union, and each of them has been addressing them in line with its own structural specifics.

At the end of the 2000s, the European Union set a course for smooth involvement of post-Soviet states into the sphere of its influence through a new system of privileged trade and economic partnership 
agreements. Russia, on its part, took steps to enhance its global reach by getting involved in the conflict in Syria and, simultaneously, by setting up institutions for cooperation and integration in the post-Soviet space, such as the Eurasian Economic Union (EAEU) (Korzhengulova, Shkvarya and Melanyina, 2017).

The confrontation of Russia and the EU over Ukraine was exactly the result of their efforts to address challenges of global dimension (Haukkala, 2015). Both parties proposed to Ukraine practically identical formats of cooperation based on integration of regulatory mechanisms and practices. The Ukrainian elite and public found themselves facing a stark choice, which led to a logjam of contradictions in society and the political system and eventually ended in a political upheaval in the winter of 2013-2014, followed by external interference and the country's plunging into a military-political crisis.

However, the main issue for the present analysis is not the dramatic events in Ukraine, but its position in the context of relations between Russia and the European Union. In this sense, the clash of the interests of the players around a particular geopolitical entity is nothing more than a derivative of Russia's and Europe's efforts to find their own place in the changing world and instruments to use for such global selfpositioning (Urnov, 2014; Gehring, Urbanski and Oberthür, 2017). Had Russia failed to turn to more structured forms of cooperation with its neighbors (EAEU) in the early 2010s, the Ukrainian authorities would have been able to comfortably sign an enhanced Partnership Agreement with the EU, and at the same time continue to develop relations with Russia. However, in 2013 the previously used patterns were no longer possible to implement.

It is noteworthy that relations between Russia and China, after the Belt and Road Initiative was launched by Beijing in 2013, have been developing according to an essentially different scenario. After some period of pondering, Moscow welcomed this initiative, and in May 2015 a Joint Statement of the Russian Federation and the People's Republic of China on Conjunction of the EAEU and the Silk Road Economic Belt was signed. In May 2018, this statement was furthered by signing a relevant agreement between the EAEU and the PRC in Astana. 
However, if we look back at the beginning of the 2010s, we will see that, just like Russia, the European Union, having lost all hope of becoming a full-fledged global player, was forced to organize in a more systemic way-on the reflective level-its immediate neighborhood where Ukraine was undoubtedly a key element. For the sake of controlling this element, i.e. solving the issue of its own self-positioning in the global and regional arena, the EU was prepared to sacrifice its relations with Russia, which it had been calling "truly strategic" (the Common Strategy of the European Union on Russia, 1999).

Let us point out that the European Union's actions which entailed a qualitative change in Russia-EU relations were not the result of some preliminary plan. In full accordance with the systemic theory of international relations, they were nothing more than a reflex response to the changes in the outside environment-a response, to which Russia, on its part, retaliated in kind.

In no smaller part, the crisis around Ukraine was ignited by the changes within the European Union (Maass, 2016). During the period of 2008-2015, European integration was faced with two major crises: the crisis of the eurozone and the migration crisis (Nyquist and Cernea, 2018; Braghiroli and Makarychev, 2018). Among the consequences of these crises were the termination of the European integration model created in the first half of the 1980s and the start of a fundamental restructuring of the entire EU political system, both at the national and, perhaps, at the pan-European levels. Measures taken to cope with the non-payment crisis in the eurozone resulted in a situation where the economic policy of the whole group of EU member-states was actually put under control of the European Central Bank and EU inter-governmental institutions. These measures have upset the entire historically formed model of European integration development.

Historically, Europe has always been confronted with the choice between two scenarios of unification. Let us designate them "unity according to Rousseau" and "unity according to Hobbes." The first one suggests a voluntary unity of European countries on issues that do not infringe on their sovereign rights. It was precisely this model that from the very start was taken as the basis of European integration 
and over the past 10-15 years has been subject to serious distortions. The second model, "according to Hobbes," is an imperial model with a strong common center. Attempts to build such a center were made, for instance, by Napoleon and Hitler. The modern European establishment was quite comfortable under the wing of European bureaucracy and practices dictated by it, notwithstanding the fact that those practices were either turning into factors limiting the development opportunities for a large group of EU member-states, or creating a situation threatening the physical security of their citizens.

A telling illustration of such state of affairs was the situation around the liquidation of the consequences of the migration crisis, which unfolded in 2015-2016. As it happened, several million refugees from the Middle East and North Africa escaping massive turmoil on their native soil were distributed quite unevenly across Europe. The greater part of the expatriates were accepted by well-off Germany, but less prosperous countries of Southern Europe also had to bear the burden of the inflow of migrants.

State and government leaders of EU countries failed to find a solution which could lead to a reform of the General Policy on Refuges. Instead, they made a separate agreement with Turkey, offering it monetary compensation for retaining migrants in its territory. Remarkably, the rule, stipulating that processing refugees' claims is the responsibility of the country whose soil they first stepped on, remains unchanged. The migration crisis triggered a drastic upsurge of right-wing sentiments, which resulted in the rightist forces' coming to power in Italy and impressive success in the elections to the European Parliament in May 2019.

All these political headwinds have placed in jeopardy the development paradigm of European integration, the way it was conceived in the first half of the 1980s. The entire political system of the EU has entered a period of profound restructuring, which cannot but influence its relations with Russia. All the more so as this is happening amid increasingly active and expanding geo-economic and geopolitical processes in Asia and Eurasia. Russia got involved in these processes from the very start and is now acting not just as a 
traditional guarantor of security in Central Asia but also as a source of new concepts for the future of Eurasia in general (Korzhengulova, Shkvarya and Melanyina, 2017).

Conceptualization of the idea of Greater Eurasia, Eurasian economic integration, and the transformation of the European Union open up new opportunities for re-building relations between Russia and the EU by abandoning past practices (typical of the 1991-2019 period). Europe, which is currently undergoing internal restructuring, will inevitably face the challenges of new Eurasian processes and will have to address them in the conditions of increasingly complicated relations with its traditional partner, the U.S. The response may be either self-isolation and limited economic cooperation with Eurasian partners or, on the contrary, more openness.

The tectonic shift was triggered by the Belt and Road Initiative, which China launched in 2013 and which Russia welcomed in 2015 in a joint Statement on Conjunction of the EAEU and the SREB. Today, the Belt and Road Initiative has become a full-fledged large-scale project of joint economic development of its participating states. In the new historical conditions, a return to the practices which prevailed in relations between Russia and Europe before the 2014 crisis, is impossible and, apparently, neither of the parties views it as expedient. However, in the mid-term perspective they may build a new model of relations based on objective assessment of systemic resources and restrictions.

Summarizing the above, I can make several conclusions and suppositions.

Firstly, in strict accordance with the postulates of the systemic theory of international relations, the European Union and Russia have been building their foreign policies in response to the challenges of the changing international environment.

Secondly, integration and strategic partnership have never been vital either to Russia or to the EU (but especially the EU) for attaining major development goals in the regional and global arena. 
Thirdly, the tasks which Russia and the EU have been solving in the context of their regional and global positioning often came into collision with each other, giving rise to conflicts.

Fourthly, the approaches of Russia and the European Union to ensuring regional security have been and still are essentially different. This circumstance was largely the reason why their relations were not frozen at the stage of stagnation (which occurred as early as 2010) but moved into a phase of military-diplomatic crisis.

Fifthly, the dramatic changes in the international environment in recent years will not let Russia and the European Union solve the tasks of their internal development and survival without entering into direct constructive cooperation.

Lastly, it is necessary to try to create flexible diplomatic mechanisms to harmonize the interests of Russia and Europe, which will enable both parties to solve their development tasks without collisions and, furthermore, use the opportunities of joint development opening up in Greater Eurasia.

\section{References}

Asmus, R., 2008. Europe's Eastern Promise: Rethinking NATO and EU Enlargement. Foreign Affairs, 87(1), pp. 95-106. Available at: http://www.jstor. org/stable/20020270 [Accessed 28 May 2019].

Baranovsky, V. and Utkin, S., 2012. Europe as Seen from Russia. Perspectives, 20(2), pp. 63-81. Available at: http://www.jstor.org/stable/23616131 [Accessed 28 May 2019].

Braghiroli, S. and Makarychev, A., 2018. Redefining Europe: Russia and the 2015 Refugee Crisis. Geopolitics, 23:4, pp. 823-848.

Casier, T., 2013. The EU-Russia Strategic Partnership: Challenging the Normative Argument. Europe-Asia Studies, 65:7, pp. 1377-1395.

Casier, T., 2016. From Logic of Competition to Conflict: Understanding the Dynamics of EU-Russia Relations. Contemporary Politics, 22:3, pp. 376-394. Available at: https://www.tandfonline.com/doi/abs/10.1080/13569775.2016.12 01311 [Accessed 28 May 2019]. 
Danilov, D. and De Spiegeleire, S., 1998. From Decoupling to Recoupling: A New Security Relationship between Russia and Western Europe? Paris: Institute for Security Studies of WEU.

Deak, A. and Kuznetsov, A., 2019. Relational Locomotive or Apple of Discord? Bilateral Perceptions of the Economic Cooperation. Journal of Contemporary European Studies, 27(3), 159-170, DOI: 10.1080/14782804.2019.1566118

Delcour, L., 2018. Dealing with the Elephant in the Room: The EU, Its 'Eastern neighbourhood' and Russia. Contemporary Politics, 24:1, pp. 14-29.

Dimitrova, I., 2010. EU-Russia Energy Diplomacy: 2010 and Beyond? Connections, 9(4), pp. 1-16. Available at: http://www.jstor.org/stable/26326221 [Accessed 28 May 2019].

EU Collective Strategy, 1999. Kollektivnaya strategia ES po otnosheniyu k Rossii [EU Collective Strategy towards Russia]. Köln Available at: https://mgimo.ru/ files2/y11_2013/243404/4.3.collective_eu_strategy.htm

Gehring, T., Urbanski, K. and Oberthür, S., 2017. The European Union as an Inadvertent Great Power: EU Actorness and the Ukraine Crisis. JCMS, Vol. 55, No. 4, pp. 727-743.

Haukkala, H., 2009. Lost in Translation. Why the EU Has Failed to Influence Russia's Development. Europe-Asia Studies, 61:10, pp. 1757-1775.

Haukkala, H., 2010. The EU-Russia Strategic Partnership: The Limits of PostSovereignty in International Relations. Routledge. 270 p. Available at: https:// www.taylorfrancis.com/books/9781135150136 [Accessed 28 May 2019].

Haukkala, H., 2015. From Cooperative to Contested Europe? The Conflict in Ukraine as a Culmination of a Long-Term Crisis in EU-Russia Relations. Journal of Contemporary European Studies, 23:1, pp. 25-40.

Kononenko, V., 2009. Russia: Strategic Loneliness. The World Today, 65(7), pp. 23-24. Available at: http://www.jstor.org/stable/41548924 [Accessed 28 May 2019].

Korzhengulova, A., Shkvarya, L. and Melanyina, M., 2017. The EU-Russia Conceptual Interaction in the Eurasian Space in the Context of Western Sanctions. Central Asia \& the Caucasus (14046091), [s. 1.], Vol. 18, No. 1, pp. 7-14.

Larrabee, F., 2003. NATO's Eastern Agenda in a New Strategic Era. Santa Monica, CA; Arlington, VA; Pittsburgh, PA: RAND Corporation, Chapter 5 Whither Russia?, pp. 115-158. Available at: http://www.jstor.org/stable/10.7249/ mr1744af.12 [Accessed 28 May 2019]. 
Leonard, M. and Popescu, N., 2007. A Power-Audit of EU-Russia Relations. European Council on Foreign Relations [online]. Available at: https://www.ecfr. eu/publications/summary/a_power_audit_of_eu_russia_relations [Accessed 28 May 2019].

Lipman, M. and Trenin, D., 2013. The End of an Era in EU-Russia Relations. Carnegie Moscow Center [online]. Available at: https://carnegie.ru/2013/05/30/ end-of-era-in-eu-russia-relations-pub-51950 [Accessed 28 May 2019].

Lukyanov, F. and Miller, A., 2017. Sderzhannost' vmesto naporistosti [Detachment instead of Aggressiveness]. Rossia v global'noi politike, No. 4. Available at: https://globalaffairs.ru/number/Sderzhannost-vmesto-naporistosti-18927 Luňák, P., 1999. Chasing a Maverick: The West's Russia Policy. Perspectives, (13), pp. 105-117. Available at: http://www.jstor.org/stable/23615946 [Accessed 28 May 2019].

Lynch, D., 2004. Russia's strategic partnership with Europe. Washington Quarterly, 27:2, pp. 99-118.

Maass, A.-S., 2016. EU-Russia Relations, 1999-2015: From Courtship to Confrontation. Routledge Contemporary Russia and Eastern Europe Series. Available at: https://www.crcpress.com/EU-Russia-Relations-1999-2015From-Courtship-to-Confrontation/Maass/p/book/9780815356141 [Accessed 28 May 2019].

Mueller, W., 2011. Recognition in Return for Détente? Journal of Cold War Studies, Vol. 13, No. 4, pp. 79-100.

Neumann, I.B., 1995. Russia and the Idea of Europe: A Study in Identity and International Relations. Routledge. $242 \mathrm{p}$.

Nitoiu, C., 2014. EU-Russia Relations: Between Conflict and Cooperation. International Politics, 51, pp. 234-253.

Nyquist,J.R.andCernea,A.M.,2018. RussianStrategyandEurope'sRefugeeCrisis. Center for Security Policy, 5. Available at: https://www.centerforsecuritypolicy. org/wp-content/uploads/2018/05/Russia_Refugee_05-28-18.pdf [Accessed 28 May 2019].

Póti, L., 2002. Putin's European Policy. In: Bugajski, Janusz, ed. Toward an Understanding of Russia: New European Perspectives, pp.135-151.

Rafiq, R. F., 2018. Eurasia and Future Geo-Strategic Calculus. Journal of Defense Resources Management, 9(1), pp. 64-75. Available at: https://search.proquest. com/docview/2178518291? accountid=45451 [Accessed 28 May 2019]. 
Roberts, C. A., 2007. Russia and the European Union: The Sources and Limits of Special Relationships. The Strategic Studies Institute.

Romano, A., 2014. Untying Cold War Knots: The EEC and Eastern Europe in the Long 1970s. Cold War History, 14:2, pp. 153-173.

Romanova, T. A., 2016. Russia and Europe: Somewhat Different, Somewhat the Same? RIAC. Policy Brief, No. 5, July. Available at: https://russiancouncil.ru/ common/upload/Russia-Europe-Policybrief5-en.pdf [Accessed 28 May 2019].

Rössler, J., 2009. Eurasia: Re-Emergence of Two World Regions. Asia Europe Journal, 7, pp. 313-326.

Schmidt-Felzmann, A., 2016. The Breakdown of the EU's Strategic partnership with Russia: From Strategic Patience towards a Strategic Failure. Cambridge Review of International Affairs, 29:1, pp. 99-127.

Shillinglaw, T., 1978. Cooperation Between CMEA and EEC. The International Lawyer, Vol. 12, No. 3, pp. 677-679.

Smith, H., 2014. Russia as a Great Power: Status Inconsistency and the Two Chechen Wars. Communist and Post-Communist Studies, Vol. 47, No 3-4, pp. 355-363.

Tichý, L. and Kratochvíl, P., 2014. The EU-Russia Energy Relations under the Prism of the Political Discourse. Perspectives, 22(1), pp. 5-32. Available at: http://www.jstor.org/stable/24624579 [Accessed 28 May 2019].

Trenin, D.V., 2002. Konets Evrazii: Rossiya na granitse mezhdu geopolitikoī $i$ globalizatsiei [The End of Eurasia: Russia between Geopolitics and Globalization]. Moscow.

Urnov, M., 2014. 'Greatpowerness' as the Key Element of Russian SelfConsciousness under Erosion. Communist and Post-Communist Studies, Vol. 47, No. 3-4, pp. 305-322.

Van der Meulen, E., 2009. Gas Supply and EU-Russia Relations. Europe-Asia Studies, 61(5), pp. 833-856. Available at: http://www.jstor.org/stable/27752304 [Accessed 28 May 2019].

Verny, S. and Vale, M., 1988. The EEC and CMEA: The Problem of Mutual Recognition. Soviet and Eastern European Foreign Trade, Vol. 24, No. 2, pp. 6-25. White, S., Light, M. and McAllister, I., 2005. Russia and the West: Is there a values gap? International Politics, 42(3), pp. 314-333. 


\title{
From Heaven to Earth
}

\section{European Identity and Historical Memory}

\author{
Dmitry V. Yefremenko
}

\begin{abstract}
The article explores the role of memory politics in building European identity. Memory politics is considered a functioning system of interactions and communication between different actors with regard to the political uses of the past. Memory politics is one of the key instruments for shaping the macro-political identity of a community. Supranational identity plays only a subsidiary role; at the supranational level, it is impossible to form a stable frame of collective memory. At the same time, European Union institutions are able to act as influential mnemonic actors to develop and implement various strategies of pro-European memory politics. Today, the strategy of recognizing the exceptional role of the Holocaust as a pan-European tragedy is subject to a fundamental revision in the EU. Attempts to "equalize" the crimes of Nazism and Communism indicate the search for an alternative mnemonic strategy. At
\end{abstract}

Dmitry V. Yefremenko, Doctor of Political Science Institute of Scientific Information on Social Sciences, Russian Academy of Sciences, Moscow, Russia.

Deputy Director

SPIN-RSCI 4587-9262

ORCID 0000-0001-6988-472X

Researcher ID Q-1907-2016

Scopus AuthorID 55372669100

Tel: +7 (499) 124-3201

E-mail: efdv2015@mail.ru

Address: 51/21 Nakhimovsky Prospect, Moscow 117997, Russia.

The research was conducted at the Institute of Scientific Information on Social Sciences of the Russian Academy of Sciences (INION RAN) with financial support from the Russian Science Foundation, Project 17-18-01589.

DOI: 10.31278/1810-6374-2019-17-3-64-84 
the European level this strategy ultimately leads not to unity, but to the disunity of European nations.

Keywords: the European Union, memory politics, supranational identity, the Holocaust, mnemonic actors, historical narratives.

W

hen continued success gives way to a string of failures, selfconfident triumphalism easily surrenders to pessimism and uncertainty. Such sentiment may overpower both large communities and institutional structures that looked omnipotent until recently. Today this is precisely what is happening to united Europe and its population of half a billion. Ivan Krastev came up with a remarkably graphic description of this feeling: "The disintegration train has left Brussels station ... It will doom the continent to disarray and global irrelevance" (Krastev, 2017, p. 2).

The European Union and the countries that join and leave it have a variety of internal and external challenges to contend with in the field of security, the economy, culture, identity, and democracy. Although of different origin, these challenges may overlap to bring about quite unexpected synergetic effects. Many onlookers have pointed to the unpreparedness of Europeans to provide a proper response to these challenges (Foa and Mounk, 2016; Lukyanov et al, 2017; Youngs and Manney, 2018), but answers will have to be found at some point. And it would be wrong to say that all of the future answers are doomed to turn out wrong. It is quite appropriate here to recall Patmos, by Friedrich Holderlin:

"But where there is danger,

A rescuing element grows as well."

In all likelihood the salvation of and a new start for the European project will come from an unexpected place, possibly even from those who today are called populists and Eurosceptics. De Gaulle's slogan Europe of Nations (Crespy and Verschueren, 2009), which modern critics of the Brussels bureaucracy have brought into the limelight, 


\section{Dmitry V. Yefremenko}

however hazy it may sound, is quite good for making an orderly retreat and regrouping forces without wasting the achievements of European integration, which are of world significance. For the Europeans (in the widest sense, including Russians, who have politically reoriented themselves to an alternative project of Greater Eurasia), it is essential to thoroughly and impartially review the entire accumulated experience of European integration. Of special significance are efforts to form a supranational identity and to look back for this purpose on the historical past of European countries and peoples.

The emergence of nation states is linked inseparably with the shaping of a special perception of the historical past by the citizens or a majority of residents in the territory where a nation is growing and maturing. The memory of the past becomes an integral part of the macropolitical identity of the emerging community. But how does this work in relation to supranational associations? Can memory politics -in other words, the politically motivated use of the historical past-produce an effective instrument of implementing an integration project, implying the delegation of a considerable share of national sovereignty to the supranational level? In this article the author considers the conceptual aspects of this group of problems, as well as the actual dynamics of memory politics within the European Union.

\section{CONSTRUCTING UNITED EUROPE'S COLLECTIVE MEMORY}

As is known, Maurice Halbwachs's works constitute the basis of all modern collective memory studies. As he developed and critically reviewed Emil Durkheim's ideas of individualism and collectivism, Halbwachs identified the dependence of individual memories on the social group to which the given individual belongs and on the individual's status within this group. Halbwachs maintains that memory is not just socially determined, but it is a process reflecting the constantly changing representations of the past. Society (social group) establishes a framework of individual memories, which may undergo considerable aberrations depending on the perception of the past within the corresponding group. The collective memory of the past does not coincide with history, while the need for a written 
history emerges precisely the moment social memory fades away or falls apart, when the social group that maintained that memory begins to leave the stage (Halbwachs, 1992). Historians and specialists on memory studies have repeatedly discussed this contrast of history and collective memory from different viewpoints, with the obvious sociologism of Halbwachs's postulate and the general vagueness of the term 'memory' being the main target of criticism (Safronova, 2018).

It is quite obvious though that the mechanisms of how the collective memory works which Halbwachs focused on are of tremendous importance to forming an individual identity and the identity of a larger community (group). However, in such a supranational association as the European Union the question arises whether collective European memory is possible in principle (Namer, 1993). Indeed, where is the group that is capable of creating an integral framework of collective European memory? This group (if it exists in reality) lacks a common language or a common nation state. The very localization of this group in space and time is a great problem.

There is no doubt that from the moment the European Coal and Steel Community was established (1951) and until now a certain group, which with a certain degree of abstraction can be called Eurocratic, was steadily consolidating itself. In the early 1990s Joseph Brodsky described the characteristic features, origin, and effects of the emergence of Eurocracy with acid sarcasm, which by no means sounds outdated at the end of the second decade of the 21st century (Brodsky, 1992). This is a group of people whose professional activity or whose close relatives are closely related to maintaining the operation of European integration institutions and the implementation of many EU projects in a variety of sectors. The Eurocratic group is socially stratified. It incorporates petty clerks and members of the transnational financial, economic, and political elite, who have many ties with representatives of such elites at the level of nation states. The group's composition, influence, resource base, and social and symbolic capital remained steadily on the ascent for decades. There is no doubt that strong affiliation with Eurocracy promotes group identity, which should be called Eurocratic too, but which serves as a natural basis 
for enhancing a wider identity, associated with the idea of a United Europe.

By and large, as empirical studies by Eurobarometer indicate, the readiness for self-identification with Europe (to a smaller extent, with the European Union) is characteristic of most EU memberstates, but this identity is purely subsidiary in relation to national identities (Westle and Segatti, 2016). Moreover, the national elites display far greater awareness of their "Europeanism" than mass groups (Deriglazova, 2018). In general, for an overwhelming majority of EU countries affiliation with the European Union and the norms, rules, advantages, and drawbacks it implies are a fact of life that is widely acknowledged but interpreted differently (Outhwaite, 2017). Self-identification exclusively with Europe is characteristic of a tiny minority of Europeans (Cotta, 2017).

By virtue of their calling and professional duties the representatives of the Eurocratic group can make a tangible contribution to proEuropean memory politics. Whatever influence Eurocrats have, though, there is no reason to believe that this group is capable of forming a supranational framework of collective memory that might take the place of national historical narratives. There is no evidence for this theory in modern Europe. At the same time, no other social group capable of coping with this task is anywhere in sight on the European horizon.

Jurgen Habermas' theory of communicative action might serve as an alternative to the search for a bearer of collective memory for one or another social group. Social communication and public discourses take center stage here, with the key role assigned to the European public sphere. Habermas maintains that the European public sphere is not a new social group for which its affiliation with Europe is primary, but rather communication between the EU countries' civil societies on critically important socio-political issues that forms a common European discourse and makes possible the emergence of a sense of communion. Such communication is extremely important for shaping European institutions and legitimating the decisions they make. It is beyond doubt that the problem of historical memory plays 
an important role in this communicative process (Triandafyllidou, Wodak, and Krzyzanowski, 2009; Risse, 2010).

The degree of influence of the European public sphere in the final count was destined to manifest itself as a significant political process for a united Europe. In 2003, when protests against the war in Iraq swept the leading EU countries, with Germany and France opposing the U.S. invasion, it seemed that supranational communication among civil societies was becoming a major political force. It was then that Jaques Derrida and Jurgen Habermas published their article "Our Renewal after the War: Europe's Second Birth" to proclaim the unequivocal appearance of the supranational public sphere on the EU's political scene, while the communication of civil society actors on the issues of Europe's past, present, and future was proclaimed the main source of common European identity. Derrida and Habermas formulated an approach towards the interpretation of historical heritage as a mechanism for constructing European identity. In their opinion it is essential to intentionally select the individual components useful for bolstering Europe's unity (Derrida and Habermas, 2003).

In considering European identity as a social construct Derrida and Habermas made a tangible contribution to the discussion of the main strategies of forming this identity (Kumar, 2003; Fligstein, 2008; Checkel and Katzenstein, 2009). One of them implies reliance on common history and socio-cultural basics of the identity being construed. The followers of this viewpoint proceed from the universalities of European culture and focus on the spatial and temporal dimensions of European identity. The other strategy of European identity is formed on the basis of a combination of purely political principles. The advocates of this approach as a rule associate European identity and EU identity as resting upon common institutions and political and legal principles.

The historical and cultural aspects of the idea of a united Europe drew the attention of philosophers and political thinkers long before the emergence of the first institutions and mechanisms of interstate integration on the European subcontinent. As Dutch scholar B. Strath points out, starting from the Middle Ages the image of the European community was created by means of isolation from the rest 


\section{Dmitry V. Yefremenko}

of the world, from the "others," while Christianity turned out the most powerful integrating factor (Stråth, 2002). In 1464, the Treaty on the Establishment of Peace Throughout Christendom, proposed by King George of Poděbrady, interpreted affiliation with Christianity as a reason for creating a league of European rulers and forming common European institutions (Treaty ..., 1964). However, the Reformation and religious wars caused a rupture of this bond. In the discourse of the Enlightenment, the term 'Europe' served as a neutral name for a common whole. Enlightenment philosophers proclaimed Western Europe the cradle of civilization and coined the term 'Eastern Europe' for its other half. This conceptual change of the map of Europe moved the backward, "barbaric" lands from the North to the East. The ambiguity of this is quite obvious: Eastern Europe was paradoxically included in the continent and placed outside its bounds.

Nevertheless, the image of the "other," "external" is central to the culturalist version of European identity. It is impossible to imagine Europe without non-Europe. However, with the beginning of European integration the political dynamics were increasingly ahead of the well-established ideas of the historical and cultural basics of European identity. The increasing relativization of Europe's historical and cultural bounds, related to dynamic processes within European culture and, in particular, to the political changes at the turn of the 20th and 21st centuries, brings to the forefront the interpretation of European identity as the political identity of the European Union.

As a rule, social groups are determined on the basis of a set of ideas the members of these groups are capable of perceiving positively. Such ideas may be expressed directly through modes of interaction and communication, or indirectly, by means of common symbols, codes, or signs. The group's members feel that they have something to share, which forms an "imagined community" (Anderson, 2006). As far as the European Union is concerned, the point at issue is an interpretation of European identity as a special political identity, which is a result of and at the same time a prerequisite for interstate integration. At the same time, cultural diversity is an integral characteristic of the European Union, but this or that form of its selection and synthesis of 
the historical narrative on the basis of this selection are fraught with conflicts and, in the final count, weakening of integration impulses. However, the actual state of affairs in the European Union over the past quarter of a century indicates that the factor of historical memory is too important for leading political actors to stop using it of their own accord.

\section{THE ROLE OF THE HOLOCAUST IN THE EU'S MEMORY POLITICS}

Achieved at the end of the 19th century, the consolidation of European nations on the basis of an awareness of racial, ethnic, and religious identity, had another side to it: the cultivation of ideas of ethnic superiority, chauvinism, and racism. The tragedies of two world wars were the result. The memory of these tragedies makes the task of constructing European identity particularly complex, because it is necessary to identify everything that is capable of uniting current EU members and potential newcomers and eliminate everything that can split them.

Until the beginning of the early 2000s, memory politics had contributed to shaping European identity on the basis of political principles. That policy's key theme was the collective memory of the Holocaust. Its main task was to analyze the tragic experience of World War II and the Nazi crimes. On the basis of an awareness of the collective guilt and responsibility of European peoples (including the population of the territories the Nazis had occupied) for the Holocaust, it became possible to form a consolidating historical narrative (Assmann, 2006). The Holocaust should have become the bond that would keep the common European historical narrative of the 20th century as an integral whole.

Alas, this did not happen. The European Union's eastward expansion in 2004 entailed a string of political compromises. An integral European historical narrative, in which the Holocaust plays the central role, eventually became one of its victims. In 2004, the EU saw an influx of new members whose historical memory was greatly different from the European one (Assmann, 2013). When a number of post-Communist countries joined the EU, an alternative version 


\section{Dmitry V. Yefremenko}

of memory politics markedly gained strength. That version put the emphasis on crimes committed by the totalitarian regimes against the people of these countries and played down the role of local forces in acts of genocide. The political elites of Central and Eastern European countries pressed for their own version of memory politics, obviously determined to underscore their equality in relations with the European Union's old-timers. Moreover, in their attempts to consolidate their equal status the elites and other mnemonic actors of Central and Eastern European countries have been consciously pushing for the transformation of approaches to the memory politics of the EU (Closa Montero, 2009; Mälksoo, 2009). As a result, some kind of mnemonical crossbreed is emerging, which Aleida Assman in the "New Discontent with Memorial Culture" presents as an ellipse with two focal points. One of the centers is the Holocaust and the other is the GULAG and mass terror during the Communist era. But glaring asymmetry remains between these historical events, which continues to split Europe (Assmann, 2013).

It goes without saying that the vision of European memory politics dynamics as a special ideological battle between "old" and "new" Europe is somewhat vulgarized. Alongside the general intention of portraying the given country in the newest version of European policy as a victim, and not the executioner or henchman, the efforts of Central and Eastern European elites stemmed from rather specific, in some cases situative, factors determined by the national political context. For instance, in formulating their own version of history memory politics, the political elites of Estonia were keen to provide a mnemonic basis not only for their efforts to secure rapid accession to NATO and the European Union, but also for their own policy towards the rights of the Russian-speaking population. This is not characteristic of all Baltic countries, but it is a specific action targeted at insulting the historical memory of a large share of non-Estonians. By and large the national framework of mobilization of historical memory remains the main one in Central and European countries (Clarke, 2014). However, moving the interpretations of historical events related to the national political agenda in these countries to the sphere of a pan-European 
discussion of the past inevitably transforms the approaches to memory politics at the national level. Moreover, these approaches begin to exert considerable influence on international relations outside the European Union.

\section{EUROPEAN SUPRANATIONAL IDENTITY: TRIAL BY POLITICS}

There are plenty of reasons to assert that in the countries of old Europe the supranational framework failed to gain the dominating positions. The failure of the European constitutional process, launched at the EU summit in December 2001, can be considered a landmark event in this sense. The drafting of an EU Constitution and preparations for the beginning of its ratification by parliaments or through national referendums in the most dramatic way transferred the debate over European identity from a purely academic dimension to the track of political struggle.

The European constitutional process was largely unprecedented, because the issue on the agenda was creation of a constitution for a space that lacked such prerequisites as territorial unity, a common language, and an integral civil society. As the drafting of the EU constitution continued, heated debate flared up over its preamble, which raised the issue of European identity (Treaty Establishing a Constitution for Europe, 2004, p. 9). The most acute polemics revolved around what eventually was completely omitted from the final version-mention of united Europe's Christian roots (Bogdandy, 2005). The decision to avoid this issue, which drew criticism from the Vatican and those EU countries where conservative Catholicism is still very strong, demonstrated the common internal contradiction of the discussion about European identity. The allusion made in the preamble to the cultural, religious, and humanist inheritance of Europe was an attempt to create a fictitious cultural basis for the European Union's political identity (Cerutti, 2005, p. 180). However, reasons of political expediency forced members of the constitutional convention to do so in the most abstract way.

The EU's constitutional process had certain chances of giving a fresh impetus to forming a pan-European identity and, respectively, 
to the development of a pan-European culture of historical memory. In any case, until 2005 there had existed enough grounds for making certain analogies with the constitutional processes in the countries that suffered a loss in World War II. In West Germany and Italy new constitutions contributed to the most radical departure from the previous interpretations of national identity, in which cultural and political identity are close to the maximum extent, if not identical, because the core of the nation state is found in the pyramidal structure of power and the assimilation of previous cultures under the aegis of national culture. The constitutions of Italy and Germany are the brightest examples of the priority of political identity, based on the values of liberal democracy and clear guarantees of civil rights and freedoms. It is these political principles and values that serve as the basis of new "constitutional patriotism," which is expected to ensure patriotism's tight link with civil freedoms and the constitution (Sternberger, 1990).

Criticism of the EU draft constitution from the liberal positions of "constitutional patriotism" was focused on explaining the origin of political values and corresponding institutions through Europe's cultural and historical heritage. Formulated in the constitutional preamble, this intention was criticized as a potentially dangerous historicist or culturalist delusion. From the standpoint of "constitutional patriotism," common history and culture are not the main determinants of political identity (Cerutti, 2005). Also, critical arguments in the spirit of European "constitutional patriotism" were aimed at preventing accusations of attempts to create a European super-nation and weaken the role of the nation state. At the political level it is EU countries that continue to play the key role, and this prevents the EU's conversion into a real federation.

Admittedly, the process of ratifying the EU Constitution produced discouraging results. The referendums in France (May 29, 2005) and the Netherlands (June 1,2005) manifested the reluctance of a majority of those who cast their ballots in these key EU countries to support the EU Constitution. It would be right to say that the European community a la Habermas, which seemingly demonstrated its strength in 2003, 
suffered a defeat in the decisive battle two years later. Although the EU signed a new treaty on reforming the system of governing the European Union at a summit in Lisbon in 2007, the failure of the constitutional project was the gravest political and psychological blow to the process of European integration. Whereas before 2005 European integration had been regarded as an indisputable success story, after the failure of the EU Constitution a string of setbacks followed (the financial crisis of 2008, the Greek debt crisis, the migration crisis, Brexit, Catalan separatism, and the growing strength of right-wing and left-wing populists and Eurosceptics). These provided enough arguments to say that the European Union experienced a systemic crisis.

\section{FROM COMMON HISTORICAL NARRATIVE TO MNEMONIC DIVERGENCE}

The failure of the European Constitution was a serious incentive for EU organizations (in the first place, the European Commission and European Parliament) to step up activity in the spheres of identity and historical memory. Besides, as stated above, the European Union's expansion in 2004 resulted in the fundamental transformation of approaches to memory politics. In 2007-2013 the EU launched the Europe for Citizens program with the aim of securing the active involvement of citizens and NGOs in the promotion of European integration. One of the program's main tasks was formulated as the promotion of a sense of European identity on the basis of common values, history, and culture for the purpose of uniting people in different parts of Europe for the sake of studying the lessons of the past and building a future. Among the concrete guidelines for the program's implementation, special attention was paid to "active European remembrance." In particular, there were plans to sponsor projects for supporting the memory of concentration camps, deportations, and repression during the period of National Socialism and the era of Stalinism. The program unequivocally accommodated the doctrines of the EU's Eastern European newcomers in the field of memory politics. The gist of the arguments in favor of the planned costs was this: without remembering the crimes of totalitarian regimes, it is impossible to properly assess the meaning of such principles of European integration 
as freedom, democracy, and respect for human rights, as well as to take an active part in European processes (European Commission, 2006).

Against this background, the European Parliament's resolution recognizing the Holocaust as a unique historical reference point (European Parliament Resolution, 2005) looked like nothing else than an attempt to compensate for the heavy bias towards memory politics formulated by the countries of New Europe. Four years later the European Parliament adopted a new resolution in favor of complementing the commemoration of the Holocaust with a Europewide Day of Remembrance for the victims of all totalitarian and authoritarian regimes (European Parliament, 2009). The proposed date was August 23, the day the Molotov-Ribbentrop Pact was signed. This was an obvious attempt to press for the version of memory politics Poland and the Baltic countries had campaigned for first and foremost. Also, that resolution was the indisputable contribution to the resumed geopolitical confrontation between Russia and the West, triggered by the EU's program of Eastern Partnership (2008).

It should be noted that the 2009 resolution contained glaring logical contradictions. On the one hand, the resolution rightly stated that it was not possible to achieve "fully objective interpretations of historical facts" and proclaimed that no political agency or political party had a monopoly on interpreting history even if it relied on a majority in parliament. On the other hand, the resolution contained a categorical statement that "Europe will not be united unless it is able to form a common view of its history, recognizes Nazism, Stalinism, and fascist and Communist regimes as a common legacy and brings about an honest and thorough debate on their crimes in the past century." Nazism was described as "the dominant historical experience of Western Europe," whereas Central and Eastern European countries have experienced both Communism and Nazism (European Parliament Resolution, 2009). As a matter of fact, while declaring that it was impossible to produce a unified interpretation of history, the authors of the resolution at once began to address the task of ideological demarcation of "right" and "wrong" interpretations of history. 
One way or another, by gradually departing from the recognition of the key role of common European responsibility for the Holocaust and enhancing the policy of self-victimization and transfer of responsibility onto "external" totalitarian forces, the initiators of the alternative version of memory politics are laying the basis for new conflicts and even "wars of memory." The basis for the conflict remains firstly because there are two historical memory frameworks (the "uniqueness of the Holocaust" vs. "Communism as an evil equal to Nazism"), and attempts to reconcile them eventually end in failure. These frameworks indicate that in forming different versions of European memory politics, a very sketchy and teleological vision of history remains, which implies a contrast between Europe's "dark past" in the 20th century and the "bright today" of the European Union, which appears almost as an embodiment of Fukuyama's "end of history" (Prutsch, 2013). Adhering to such a viewpoint inevitably overlooks other, very important components of the European historical heritage, such as imperialism and colonialism. It is still more important that the "dark past" is lent the status of a negative "EU origin myth," which paves the way for the ideological instrumentalization and moralization of the past and eases the incentives to a critical study of stereotypes and "holy cows" of one's own national history.

At the same time, at the level of many of the EU's nation states, specific historical and political factors make it difficult to accept the equalization of the Nazi-Communism parallel. In particular, this is clearly seen in countries where left-of-center forces have been and remain influential political actors and the role of local Communist parties was not confined to the role of "the Kremlin's agents of influence." In Spain, for instance, the condemnation of Communism is perceived through the lens of a modern vision of the tragic experience of the Spanish Civil War in the 1930s and as a condemnation of the loser party, which according to many Spaniards deserves sympathy. In such countries as Croatia and Slovakia, on the contrary, problems emerge due to the unconditional condemnation of Nazism, because it was the Third Reich that sponsored the emergence of client states that, despite the complicity of the Pavelic and Tiso regimes in crimes 
against humanity, are associated by many Croats and Slovaks with modern history's first experience of building a nation state.

\section{CONCLUSION}

The case of the European Union is extremely important and indicative for studying the entire set of memory politics problems and its links with political and cultural identity. Firstly, this is an extraordinary case, because from the standpoint of the depth and diversity of integration processes, the European Union has no equals among other economic and political supranational associations. Also, the EU's case is extraordinary because it is highly likely that the current crisis could bring about a U-turn and return part of the powers to the level of national governments and parliaments, as well as the recognition of political, social, and economic disproportions between countries through the transition to a model of multi-speed integration (Piris, 2012; Fossum, 2015; Leruth and Lord, 2015; Martinico, 2015). The scale of the European project is favorable for the creation of a supranational identity, even more so, since at the early stages of Euro-integration the creation of a united Europe began to be linked at the official level with such matters as identity, common heritage, and cultural proximity (Declaration on European Identity, 1973). However, despite the systemic work in building a supranational identity of a united Europe, this identity remains auxiliary in relation to the identities pertaining to the nation state, a common language, culture, and historical heritage. Representatives of very different communities and social groups are prepared to declare their European identity as an auxiliary one. At the same time, the importance of public communication concerning the most important aspects of European identity and Europe's past and future are hard to overestimate, because it can and does exert strong influence on the making of political decisions, including those concerning memory politics.

In the European Union major actors capable of forming a memory politics strategy and influence its implementation operate both at the national and supranational levels. The EU's political governance institutions are actors that make a very important contribution to 
pro-European memory politics. In their official documents, Brussels and Strasbourg determine common strategies and concrete actions concerning memory politics. EU institutions have significant resources and instruments at their disposal to implement measures capable of using the historical past for political purposes. However, while further actions will remain relatively autonomous, determining the basic political position of the EU's supranational agencies is related to achieving a balance of interests and approaches of affiliated member-states. The transformation of a European memory politics strategy is very indicative in this respect: whereas before the accession of Central and Eastern European countries to the EU the recognition of the unique role of the Holocaust tragedy was the basis of memory politics, after the expansion of the EU in 2004 a fundamental turn took place and the crimes of National Socialism began to be equalized with the crimes of the Communist regimes. Lastly, the "modified" version of common European memory politics has also begun to be used ever more actively for geopolitical purposes to create a new mental frontier that is expected to divide the European geographic and cultural space once again, forcing Russia out, but retaining all other post-Soviet countries included in the Eastern Partnership program.

In the process of regaining its well-familiar role of a significant "other" on the billboard of European memory politics, Russia lacked the opportunity to exert considerable influence on the transformation of that policy. Certain warnings from Russian intellectuals, a professional dialogue (in particular, within the framework of commissions where Russian historians discussed complex issues of the past with historians from Germany, Poland, Latvia, and some other EU countries), and the activity of State Duma and Federation Council members on the platform of the Parliamentary Assembly of the Council of Europe were unable to act as a counterbalance to the systemic work that was conducted within EU agencies and in the public space of united Europe. It would rather be appropriate to say that the turn in the European memory politics had a strong influence on memory politics in Russia (Miller, 2016). 
It goes without saying that the version of European memory politics that attaches the key role to the Holocaust tragedy and the vision of Nazism as the absolute evil is quite comparable with Russia's modern memory politics, in which the Great Victory over Hitler's Germany is the central element of the semantic structure of the country's past (Malinova, 2017). The alternative version of European memory politics, in which Nazism and Communism are interpreted as identical twins (the latter portrayed as a totalitarian ideology imposed from outside by the Soviet Union, and repressive practice) makes illusory the outlook for a rapprochement of models of the political interpretation of history.

However deep the current political divides between Moscow and Brussels can be, the historical narratives, in which the liberation of Auschwitz and the linkup on the Elbe are the most important symbolic benchmarks, retain their place as the basis for a dialogue on a joint future. If one of the parties keeps pressing with growing intensity for a narrative revolving around the joint parade by the Wehrmacht and the Red Army in Brest as the main symbol, the hard-going dialogue dies down and instead one hears two monologues, as neither speaker is interested in listening to and hearing each other.

In the current circumstances, Central European and Eastern European elites and the new cohorts of Eurocracy are keen to preserve the vector of the EU's memory politics aimed not so much at forming a supranational identity of united Europe as at adjusting the tragic experience of the 20th century history to the political targets of these forces. The counterarguments of this sort of memory politics in the final count are aimed at ruining the ideas of Europe's civilizational unity, of which Russian history and culture are an integral part. And they will stop no one. Changing the vector is possible, but this will most probably happen in the context of a wider transformation of the European project, reconsideration of its tasks, and the establishment of a considerably new balance between national and supranational. 


\section{References}

Anderson, B., 2006. Imagined Communities. Reflections on the Origin and Spread of Nationalism. Revised Edition. London-New York: Verso.

Assman, A., 2006. Der lange Schatten der Vergangenheit. Erinnerungskultur und Geschichtspolitik [The Long Shadow of the Past. Memory Culture and History Policy]. München: C.H. Beck.

Assman, A., 2013. Das neue Unbehagen an der Erinnerungskultur. Eine Intervention [The New Discomfort at the Memory Culture. An Intervention]. München: C.H. Beck.

Bogdandy, A., 2005. The European Constitution and European Identity: Text and Subtext of the Treaty Establishing Constitution for Europe. International Journal of Constitutional Law, 3(2-3), pp. 295-315.

Brodsky, J., 1992. What the Moon Sees. Yale Review, 80(3), pp. 18-22.

Cerutti, F., 2005. Constitution and Political Identity in Europe. In: Liebert, F., (ed.) Postnational Constitutionalisation in the Enlarged Europe: Foundations, Procedures, Prospects. Baden-Baden: Nomos, pp. 172-190.

Checkel, J. and Katzenstein, P. (eds.), 2009. European Identity. Cambridge: Cambridge University Press.

Clarke, D., 2014. Communism and Memory Politics in the European Union. Central Europe, 12(1), pp. 99-114, DOI: 10.1179/1479096314Z.00000000018.

Closa Montero, C., 2009. Politics of Memory: What Is the Role for the EU? In: European Parliament. Europe 70 Years after the Molotov-Ribbentrop Pact. Vilnius: Margi Raštai, pp. 111-131.

Cotta, M., 2017. Evropeīskaya identichnost': Vyzovy sovremennosti [European Identity: Challenges of Modernity]. In: Semenenko, I. (ed.) Identichnost': lichnost', obshestvo, politika [Identity: Personality, Society, Politics]. Moscow: Ves' mir.

Crespy, A. and Verschueren, N., 2009. From Euroscepticism to Resistance to European Integration: An Interdisciplinary Perspective. Perspectives on European Politics and Society, 10(3), pp. 377-393.

Declaration on European Identity, 1973. Document on The European Identity published by the Nine Foreign Ministers on 14 December 1973, Copenhagen. Available at: <https://www.cvce.eu/obj/declaration_on_european_identity_ copenhagen_14_december_1973-en-02798dc9-9c69-4b7d-b2c9f03a8db7da32.html> [Accessed 22 March 2019]. 
Deriglazova, L., 2018. Russia and the European Union in Eulerian Circles of "Europe". Russia in Global Affairs, 16(4), October-December, pp. 8-30. DOI: 10.31278/2618-9844-2018-16-4-8-30.

Derrida, J. and Habermas, J., 2003. Unsere Erneuerung. Nach dem Krieg: Die Wiedergeburt Europas [Our Renewal. After the War: The Rebirth of Europe]. Frankfurter Allgemeine Zeitung, 31 May.

European Commission, 2006. The Europeans, Culture and Cultural Values. Qualitative Study in 27 European Countries. Summary Report. Brussels, June. [online]. Available at: <http://ec.europa.eu/culture/pdf/doc964_en.pdf> [Accessed 22 March 2019].

European Parliament Resolution, 2005. European Parliament Resolution on Remembrance of the Holocaust, Anti-Semitism and Racism. Official Journal of the European Union, C 253 E, 13.10. [online]. Available at: <http://eur-lex. europa.eu/LexUriServ> [Accessed 22 March 2019].

European Parliament Resolution, 2009. European Parliament Resolution on European Conscience and Totalitarianism. Official Journal of the European Union, 27 May. [online]. Available at: <http://eurlex.europa.eu/LexUriServ/ LexUriServ.do?uri=OJ:C:2010:137E:0025:0027:EN:PDF> [Accessed 22 March 2019].

Fligstein, N., 2008. Euro-Clash. The EU, European Identity, and the Future of Europe. Oxford: Oxford University Press.

Foa, R. and Mounk, Y., 2016. The Danger of Deconsolidation: The Democratic Disconnect. Journal of Democracy, 27(3), pp. 5-17.

Fossum, J., 2015. Democracy and Differentiation in Europe. Journal of European Public Policy, 22(6), p. 799-815.

Halbwachs, M., 1992. On Collective Memory. Chicago: Chicago University Press.

Krastev, I., 2017. After Europe. Philadelphia: University of Pennsylvania Press.

Kumar, K., 2003. The Idea of Europe: Cultural Legacies, Transnational Imaginings and the Nation-State. In: M. Berezin and M. Schain (eds.) Europe Without Borders: Remapping Territory, Citizenship and Identity in a Transnational Age. London: John Hopkins University Press.

Leruth, B. and Lord, C., 2015. Differentiated Integration in the European Union: A Concept, a Process, a System or a Theory? Journal of European Public Policy, 22(6), pp. 754-763. 
Lukyanov, F. et al., 2017. Global Revolt and Global Order. The Revolutionary Situation in Condition of the World and What to Do About It. Valdai Discussion Club Papers [online]. Available at: http://valdaiclub.com/a/reports/valdai-clubreport-global-revolt-and-global-order/ [Accessed 23 March 2019].

Malinova, O., 2017. Political Uses of the Great Patriotic War in Post-Soviet Russia from Yeltsin to Putin. In: Fedor, J., Kangaspuro, M., Lassila. J. et al. (eds.) War and Memory in Russia, Ukraine and Belarus. Basingstoke: Palgrave Macmillan.

Mälksoo, M., 2009. The Memory Politics of Becoming European: The East European Subalterns and the Collective Memory of Europe. European Journal of International Relations, 15(4), pp. 653-680. DOI: 10.1177/1354066109345049.

Martinico, G., 2015. A Multi-Speed EU? An Institutional and Legal Assessment. Rome: Istituto Affari Internazionali.

Miller, A., 2016. Memory Control. Historical Policy in Post-Communist Europe. Russia in Global Affairs, 3, pp. 162-176.

Namer, G., 1993. Une mémoire collective européenne est-elle possible? [Is European Collective Memory Possible?]. Revue suisse de sociologie, 19(1), pp. 25-32.

Outhwaite, W., 2017. Contemporary Europe. London-New York: Routledge.

Piris, J.-C., 2012. The Future of Europe. Towards a Two-Speed EU? Cambridge: Cambridge University Press.

Prutsch, M., 2013. European Historical Memory: Policies, Challenges and Perspectives. European Parliament. Directorate General for Internal Policies. Policy Department B: Structural and Cohesion Policies. Brussels. [online]. Available at: <http://www.europarl.europa.eu/RegData/etudes/ STUD/2015/540364/IPOL_STU\%282015\%29540364_EN.pdf> [Accessed 22 March 2019].

Risse, T., 2010. A Community of Europeans? Transnational Identities and Public Spheres. London: Cornell University Press.

Safronova, Y., 2018. Tret'a volna Memory Studies: dvadtsat' tri goda protiv shersti [The Third Wave of Memory Studies: Going Against the Grain for Twenty-Three Years]. Politicheskaya nauka, 3, pp. 12-27.

Sternberger, D., 1990. Verfassungspatriotismus [Constitutional Patriotism]. In: Sternberger D. (ed.) Verfassungspatriotismus [Constitutional Patriotism]. Frankfurt a. M.: Insel Verlag, pp. 3-12. 
Stråth, B., 2002. A European Identity. To the Historical Limits of a Concept. European Journal of Social Theory, 5(4), pp. 387-401. DOI $10.1177 / 136843102760513965$

Treaty Establishing a Constitution for Europe, 2004. [online]. Available at: $<$ https://europa.eu/european-union/sites/europaeu/files/docs/body/treaty_ establishing_a_constitution_for_europe_en.pdf> [Accessed 28 March 2019].

Treaty on the Establishment of Peace throughout Christendom, 1964. In: Vaněček, V. (ed.) The Universal Peace Organization of King George of Bohemia: A Fifteenth Century Plan for World Peace 1462 / 1464. Prague: Publishing House of the Czechoslovak Academy of Sciences.

Triandafyllidou, A., Wodak, R. and Krzyzanowski, M. (eds.), 2009. The European Public Sphere and the Media: Europe in Crisis. London: Palgrave Macmillan.

Youngs, R. and Manney, S., 2018. Recession and Renewal in European Democracy. Carnegie Europe. [online]. Available at: https://carnegieeurope. eu/2018/02/26/recession-and-renewal-in-european-democracy-pub-75601 [Accessed 22 March 2019].

Westle, B. and Segatti. P. (eds.), 2016. European Identity in the Context of National Identity. Questions of Identity in Sixteen European Countries in the Wake of the Financial Crisis of 2007 and 2009. Oxford: Oxford University Press. 


\section{Warfare in the 21st Century}

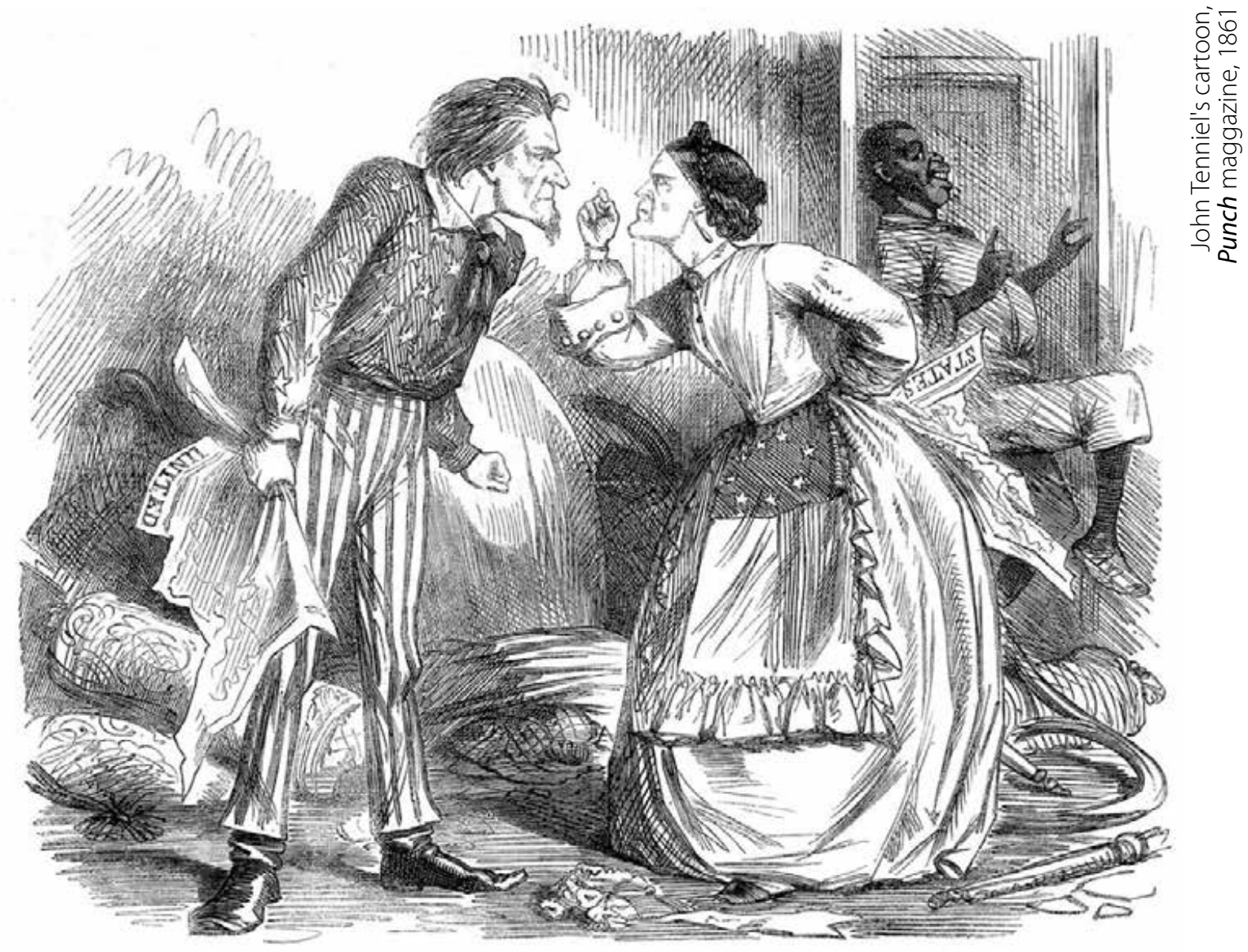

A FAMILY QUARREL.

66 The crisis of institutions and regimes created in the bipolar era gradually led to the collapse of military-political coalitions, which increases the need for flexible coalition strategies amid dwindling trust among key players and a shortage of common values. 99 


\section{Rethinking Sanctions Efficiency}

\section{Evidence from 205 Cases of the U.S. Government Enforcement Actions against Business}

Ivan N. Timofeev

\section{Abstract}

The article revisits the issue of economic sanctions efficiency. It concentrates on changes in business behavior when it is affected by governmental enforcement actions. The empirical groundwork is composed of 205 cases of U.S. governmental investigations vis a vis business in 2009-2019. The article tests two major hypotheses. The first one is about the measure of rationality of business when it violates existing sanctions regulations. The second one is about changes in business behavior during and after the investigation. Descriptive statistics shows that violations are rather not planned in advance. Reckless behavior is much more frequent than willful one. However, the data confirm the hypothesis about the transformation of business behavior during and after the OFAC investigation. This is an indicator of the high efficiency of

Ivan N. Timofeev, Ph.D. (Political Science)

MGIMO University, Moscow, Russia

Associate Professor;

Russian International Affairs Council, Moscow, Russia

Program Director

SPIN-RSCI: 3517-3084

Tel: +7(495)434-67-66

E-mail: itimofeev@russiancouncil.ru

Address: Office 324, 76 Vernadsky Prospect, Moscow 119454, Russia.

The research is supported by a grant of the Russian Science Foundation (Project 18-18-00439). 
sanctions against businesses as compared with relatively low efficiency vis a vis states.

Keywords: sanctions, U.S. Department of the Treasury, Office of Foreign Assets Control (OFAC), business, sanctions effectiveness, enforcement action, compliance.

\section{PROBLEM STATEMENT}

The question of whether economic sanctions are effective as a foreign policy tool has for a long time been central for the students of sanctions policy. Scholars have been rather skeptical about the utility of sanctions. Early research by Hufbauer et al. (1990) identified that only one-third of sanctions programs affected the behavior of a targeted state. Further critical reviews of their database showed even more pessimistic results, claiming that only $5 \%$ of sanctions were a success (Pape, 1997). Drezner (1999) coined the term 'sanctions paradox.' He concluded that moderate sanctions against allies are more effective than comprehensive restrictions against foes. Despite the mounting sanctions programs since the end of the Cold War and a significant improvement of restriction tools, there is still no confidence that the imposition of sanctions provides positive results (Rosenberg et al. 2016). Jaeger has recently pointed out that evaluations of sanctions effectiveness often include a significant degree of subjectivity (Jaeger 2018, p. 15). Darsey and Stulberg (2019) have stated that sanctions acquire different meanings as a concept in different national contexts.

Still, sanctions remain among the main foreign policy tools of Western countries. The U.S. has been the global leader in the use of sanctions and has imposed them more often than all other states and international organizations combined (Hufbauer et al., 2010, pp. $5,17)$. This may mean that despite controversial results, sanctions remain functional for one reason or another. To understand the towering demand for sanctions as a political tool one needs to revisit the concept of sanctions effectiveness as such. 
The "traditional" understanding of sanctions effectiveness implies an ability to change the behavior of a targeted state. By means of economic restrictions (trade embargos, financial bans, investment prohibitions, sectoral restrictions, etc.) the initiator or a coalition of initiators intends to force a targeted state to change its foreign or domestic policy. Coercion is the principal function of sanctions. Therefore, the effectiveness of restrictions is often linked to the change of a targeted state's foreign or domestic policy. Hufbauer et al. (1990, 2010) provided a benchmark for such an approach.

Coercion usually goes hand in hand with attempts to constrain the capabilities of a targeted state. Sanctions often aim to limit its military, technological or economic capabilities and punish it by inflicting economic damage. For instance, Neuenkirch and Neumeier (2015) compared the economic damage caused by U.S. and UN sanctions. Another important function is sending a signal to a targeted state. Restrictions may be symbolic in terms of damage, but they send a clear signal of discontent by the initiator. The signaling function has increasingly become of interest to scholars in recent years (see, for instance, Bapat et al., 2013). In terms of Drezner's 'sanctions paradox', signaling may be effective in relations with allies and partners.

Coercion, constraining and signaling are regarded as the functional core of sanctions and as a policy tool in contemporary research (Giumelli, 2016). These three functions have provided the background for numerous case studies, including those of Iran (Graef, 2013; Maloney, 2015; Nephew, 2018), North Korea (Kim, 2014; Haggard and Noland, 2017), Cuba (Spadoni, 2010), China (Cooper and Lorber, 2016), and Russia (Connolly, 2015, 2018; Kholodilin and Netsunaev, 2017, 2016; Fritsz et al., 2017; Crozet and Hinz, 2016; Moret et al., 2017).

There are also several other dimensions of sanctions effectiveness such as the impact of sanctions on human rights. The severe damage from a comprehensive embargo against the Iraqi population in 1991 fueled the search for ways to alleviate people's sufferings. Thus, the effectiveness of sanctions also implies their selective potential to affect the elites and certain individuals, not people in general. The terms 'targeted sanctions', 'smart sanctions' and 'surgical sanctions' 
emerged in the conceptual discourse in the 1990s and have become especially popular in the 21st century (Drezner, 2015; Tourinho, 2015). Globalization and advances in financial intelligence provided the U.S. with an opportunity to use targeted measures on a completely different scale compared with the past practices (Zarate, 2013). However, there is much skepticism about the ability of 'smart sanctions' to avoid causing peoples' suffering and violation of human rights (Jazairi, 2015, 2018).

The success of sanctions may also mean internal changes in a targeted state. Here effectiveness may imply democratization or public revolt fueled by blocking the resources available to the political elite. However, the link between sanctions and democratization is not clear. Sanctions may even stimulate consolidation of the targeted regime instead of its collapse (Grauvogel and Soest, 2014), although some authors claim that the international community should continue to use sanctions in order to fight the threats to democratization (Marinov and Neli, 2015). Other scholars (e.g., Whang, 2011) have noted the use of sanctions for addressing internal issues in the initiator state.

All of these studies place emphasis on the state as a key actor. They follow a "state-centric" approach in a sense that they associate the success of sanctions with the behavior of a state, its capabilities and strategies. However, states are not the only target of sanctions. Private companies and business in general are targets too, especially if one takes into account the rise of 'smart sanctions' in recent years. Furthermore, there is the increasing use of 'secondary sanctions' which imply punishment of individuals and entities that are dealing with the sanctioned states or entities. Secondary restrictions imply "sanctions for violations of sanctions." U.S. regulators often implement secondary sanctions against American and foreign businesses. Many foreign businesses may be potentially subject to U.S. sanctions that involve restrictions in the use of the U.S. dollar as a key means of international payments. Secondary sanctions may be an important factor in affecting the behavior of businesses in their relations with a sanctioned state or entities. These sanctions apparently provide the U.S. government with another powerful leverage to increase the pressure on targeted states, compelling international businesses to abstain from cooperation with them. 
This article intends to analyze the efficiency of sanctions from a different angle compared to the "old-school" approach. Instead of looking at the change of the targeted state's behavior, it focuses on the use of secondary sanctions against business. It studies the impact of penalties imposed by the U.S. government on companies and individuals for commercial connections with targeted businesses and states, and the violations of U.S. sanctions programs. In other words, the study uses a "business-centric" approach to analyze sanctions efficiency instead of the "state-centric" one. Early and Preble (2018) have recently provided an example of such an approach.

The key issues of the research include patterns of violations of U.S. sanctions by businesses; strategies of business in dealing with the U.S. regulators; and the consequent impact of sanctions on businesses' behavior in terms of their attempts to further violate U.S. sanctions. The main question to answer is: Do penalties imposed by U.S. regulators (mostly by the U.S. Department of the Treasury) change the behavior of business in favor of compliance with the U.S.s demands?

To answer the question above this paper tests two hypotheses. Hypothesis 1 postulates that business violates sanctions regimes in order to maximize its profits in general or to increase the profits of its branches or subsidiaries. In other words, business violates rules rationally. This assumption will be disproved if business demonstrates other patterns leading to violations.

Hypothesis 2 suggests that U.S. secondary sanctions against companies significantly affect their behavior and make them comply with U.S. regulations. Compliance is a rational strategy to minimize further financial and reputational losses caused by the regulators' punitive measures. Presumably, U.S. sanctions implemented in line with the "business-centric approach" may be much more effective compared with the "state-centric" sanctions. The effectiveness of sanctions against business is one of the reasons why sanctions are still functional and remain an important foreign policy tool. This assumption will be disproved if business does not generally change its behavior and continues violations regardless of the punitive measures imposed by U.S. regulators. 


\section{RESEARCH DESIGN}

To understand the correlation between U.S. regulators' policy and its impact on the behavior of targeted businesses we must first define and further operationalize what is exactly understood by 'policy' and 'behavior.' For the purposes of this paper 'policy' means certain actions by the U.S. governmental authorities to guarantee that business complies with existing sanctions programs and legislation. 'Behavior' means actions of business in terms of compliance with imposed sanctions. This research deals with cases when business violates imposed sanctions for one reason or another, while governmental regulators react with punitive measures in order to change the behavior of the violators.

The U.S. Department of the Treasury Office of Foreign Assets Control (OFAC) is a key governmental regulator, although in some cases other regulators take part in coercive actions. The Department of Justice, the Department of Commerce, the Federal Reserve System Board of Governors and other institutions may participate in investigations vis a vis American and foreign businesses. However, OFAC usually plays the leading role in relations with business.

Generally, OFAC implements two basic options to punish a violator. The first one is to include it in the SDN list which prohibits U.S. persons and entities under U.S. jurisdiction from dealing with a violator economically. The second option is to impose a financial penalty. This study analyzes the second measure only, because the SDN-list option does not leave many choices for a company or a person to change its behavior. Although the SDN-track is an interesting topic per se, it does not provide necessary argumentation to support or oppose my hypotheses. Financial penalties are apparently a more flexible tool. Its aim is not to exclude a violator from the international economy, but to change its behavior. Another critical factor for such a choice is the availability of empirical data. Although the SDN and other OFAC lists are publicly available, it is not always easy to identify the ways of a person's behavior prior to violation, and it is still harder to assess a person's behavior when he is already on the list. On the contrary, information about penalties provides enough evidence of the causes 
of violations, reaction of the U.S. regulator, and consequent behavior of a violator, whether it is an individual or a company.

The present study uses OFAC settlement agreements with companies, organizations and individuals as a major source. OFAC presents it in textual form. To transform this information into standardized data, the information was coded and transformed into a quantitative database. As a result, an OFAC Quantified Enforcement Database (OQED) has been created.

Coding and quantification are possible due to the similar structure of settlement agreements. Moreover, OFAC provides formal "Economic Sanctions Enforcement Guidelines" (Federal Register, 2009). This document defines financial penalties' calculation procedures. It also identifies aggravating and mitigating factors that affect the measure of punishment. Settlement agreements usually provide a schematic overview of the kind of violations, patterns of behavior prior to the violations, level of cooperation with OFAC by a company or person under investigation, and consequent measures taken to improve compliance with sanctions regulations. Enforcement guidelines and settlement agreements imply specific outcomes of actions taken by OFAC and by a person/company under investigation. Most of these outcomes can be formalized in a binary $1 \backslash 0$ code.

To test the hypotheses, the behavior of businesses has been operationalized in a number of variables.

Hypothesis 1 claims that a business acts rationally to break the sanctions rules. The main way to check this is to see whether OFAC identifies violations as willful or not. A willful violation would mean that a company had an initial plan to violate the regulations. Other variables include the following questions: Did the company attempt to conceal violations? Was it a regular practice or an isolated case? Was the company management aware of the violation? Did the company voluntarily disclose its violation to OFAC or other regulators?

OFAC qualifies violations as egregious or non-egregious. Willful violations almost automatically lead to an egregious status. However, egregious cases may not always be willful. Some of them represent reckless behavior, resulting, for instance, from ignorance 
about existing regulations. Reckless behavior does not mean that the company acted intentionally (rationally) to violate sanctions regulations. However, a company could, for instance, save resources necessary for the compliance program, external audit, personnel training, etc. An important variable for determining the degree of a company's investment to avoid violation of sanctions in advance is the existence of an effective compliance program as defined by OFAC in a settlement agreement. The absence of voluntary self-disclosure may signal reckless, although not willful, behavior. The abovementioned variables, such as management awareness about a violation, an attempt to conceal a violation, and the pattern of conduct, may also indicate that a company tries to rationally limit the damage from breaking the sanctions rules, while not informing the regulator about this.

In sum, the "rationality" to violate sanctions has two dimensions. The first one is willful behavior and the intention to maximize profit by violating the sanctions. The second one is reckless behavior, which may mean the intention to reduce compliance costs. Such a strategy may lead to mistakes in decision-making and to misbehavior. This is a situation where a short-term rationality causes losses in the long run.

A particular case does not fit into the hypothesis about the rational causes of misbehavior if violations were caused by inaccuracy, software malfunction, single (non-systematic) violations, etc. Usually, such violations are qualified by OFAC as non-egregious.

Hypothesis 2 requires operationalization of the change in the behavior of companies when affected by OFAC and other regulators. Voluntary self-disclosure is an important variable. However, its absence may not necessarily mean that a company intended to abstain from cooperation with OFAC. This may be the result of unawareness about a violation. However, other variables may be more illustrative. The first one is whether a company cooperates with an OFAC investigation in one way or another (by signing a tolling agreement, accurately providing documents, promptly responding to OFAC's requests, providing it with relevant information, reviewing other violations). The second variable is whether an entity takes remedial measures to improve the environment which caused the violation. These cases are 
recorded and treated as a specific variable for a particular measure: creation or improvement of a compliance program, personnel training, dismissal of managers responsible for violations, financial and human enforcement of a compliance program, external audits, preparation of compliance manuals, and due diligence of partners. Another important variable is the history of violations. OFAC regards a new violation as an aggravating factor if it has been committed within five years after the previous one. Repeated violations indicate that the long-term effect of OFAC's action is poor.

In other words, change of a company's behavior means that it cooperates with the investigation, takes remedial measures, and does not violate U.S. regulations again. However, the "history" variable should be treated carefully. Investigations may take seven to eight years. Existing data may simply omit cases of repeated violations which may emerge in the future.

Besides these variables, the OQED also includes statistics on base penalties, final penalties and statutory maximum penalties imposed by OFAC. It also includes national and sectoral classification of companies, the number of violations by a single person or entity, information about violated programs, duration of the investigation, and the participation of governmental regulators other than OFAC.

The database contains 73 variables. The analysis included the study of 205 OFAC enforcement cases from January 2009 to June 2019. The OFAC data provide settlement agreements up until 2003. However, the 2003-2008 documents significantly lack critical information and were excluded from the analysis. Early and Preble (2018) have made an analysis of the entire period, though with different research goals and assumptions.

\section{ANALYSIS}

\section{Preliminary observation}

The first important observation of the OQED descriptive statistics is the distribution of the national origin of individuals and entities under OFAC investigations. The majority of them are U.S. companies: 137 out of 205 cases. EU companies account for 40 cases. Other countries 
of origin include Switzerland (5), China (4), Japan (3), and 11 other nationals (Fig. 1).

Fig. 1. National Origin of Companies and Individuals under OFAC Investigations in 2009-2019

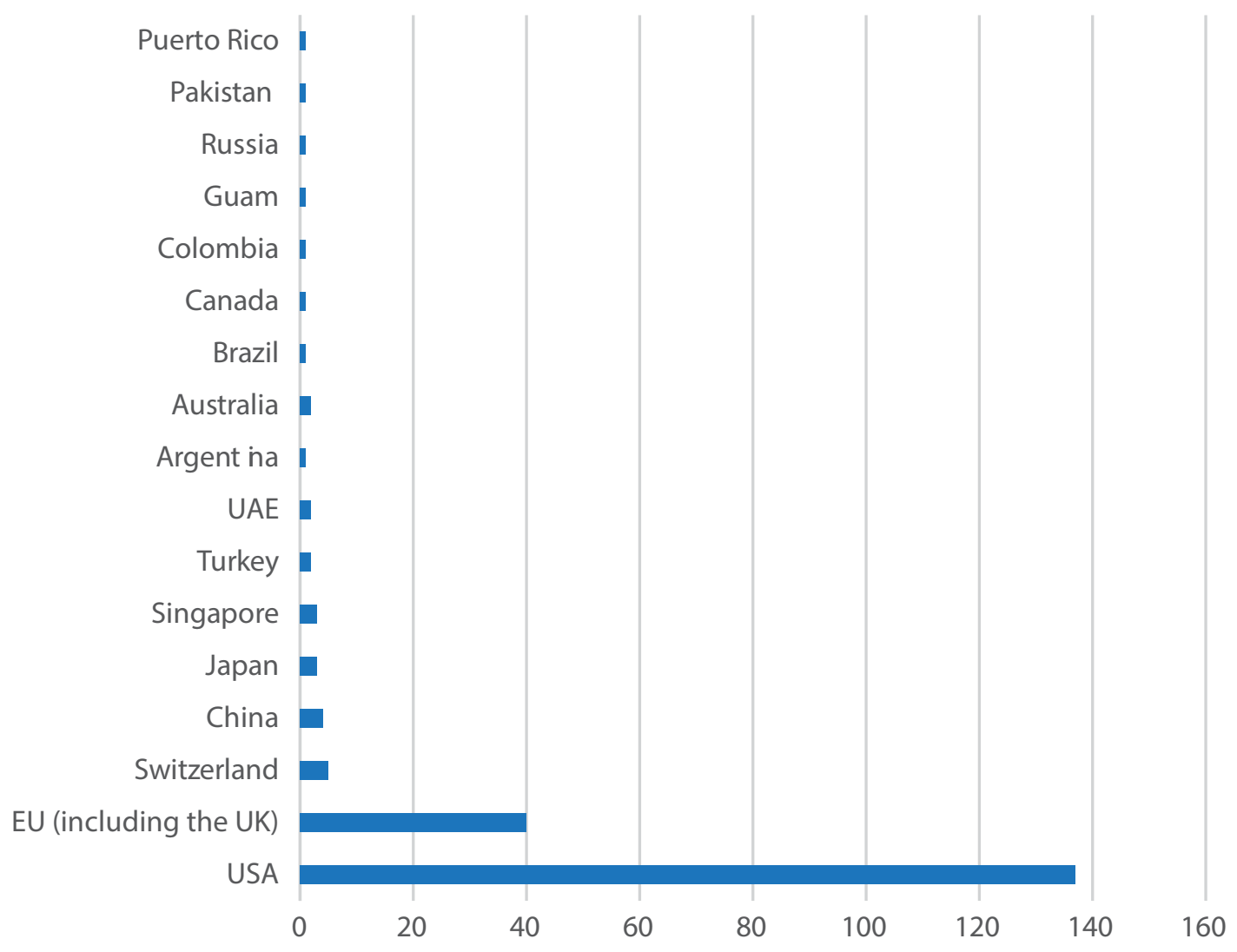

However, the U.S. skew should be misleading. American companies pay much less in penalties. They have agreed to pay $\$ 177.7$ million of the overall $\$ 5.63$ billion gathered by OFAC during a 10 -year period. This means that the share of U.S. companies is only $3.15 \%$. At the same time, EU companies have agreed to pay $\$ 4.67$ billion, which is $82 \%$ of the overall gains by OFAC in ten years. In other words, 40 EU companies have payed 26 times more than 137 U.S. entities and individuals combined (Fig. 2).

A majority of European payments were made by financial institutions. The analysis of sectoral distributions shows that the financial sector is a key contributor of payments to OFAC. Financial companies (mostly banks) account for 53 cases out of 205 . This is the most frequently sanctioned industry (Fig. 3). 
Fig. 2. Share of the U.S., the EU and China in the Overall Payments to OFAC in 2009-2019

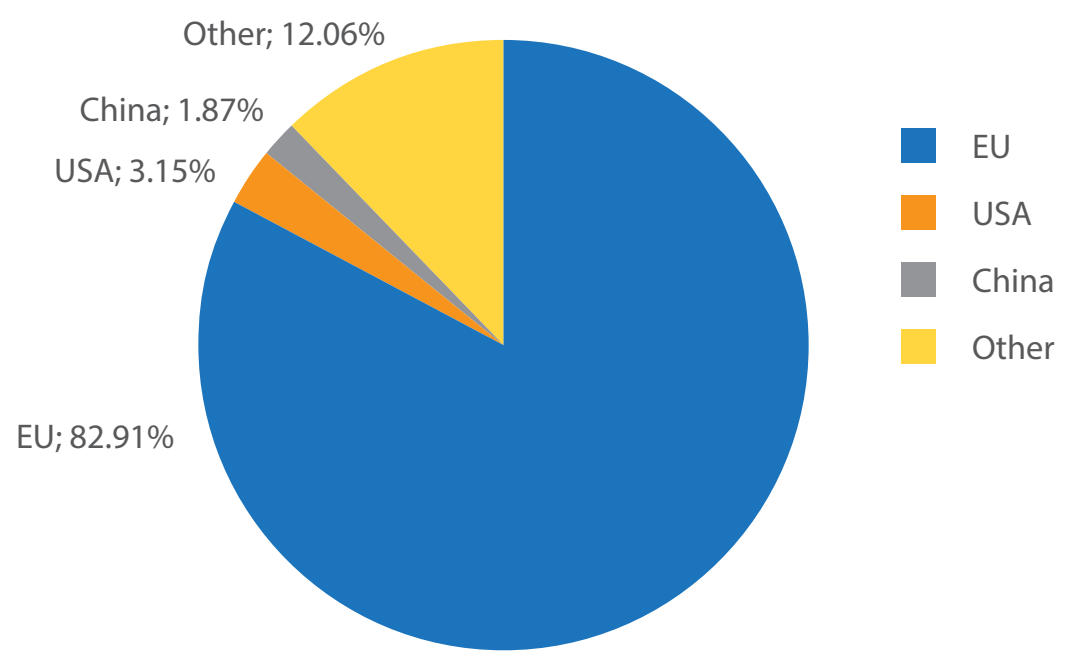

Fig. 3. Sectoral Origin of Businesses under OFAC Investigations in 2009-2019

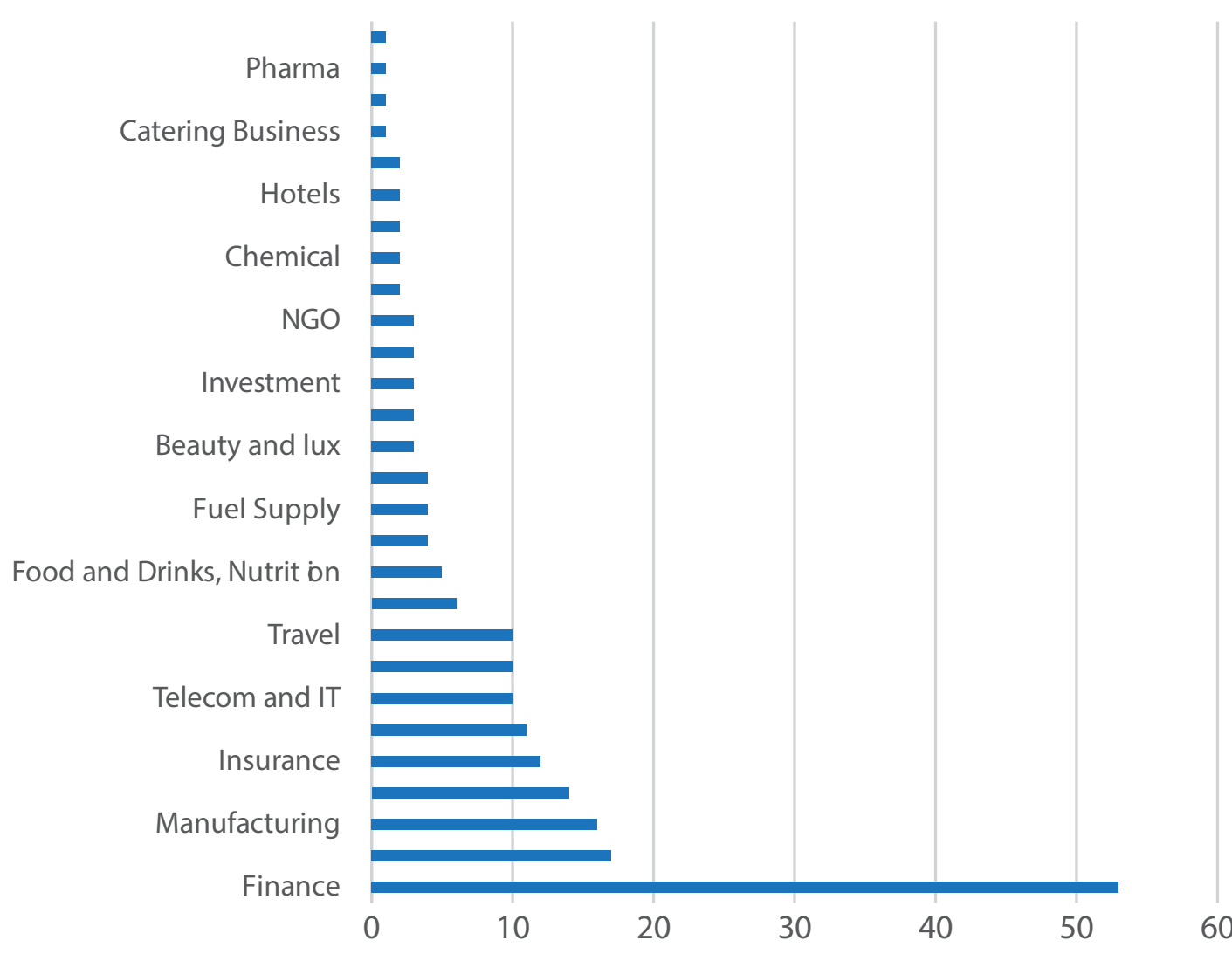

There are plenty of other sectors (oil and oil-service companies, telecoms, aerospace firms, insurance, investment, trade, manufacturing 
and other businesses). However, their representation is not as big as that of banks. At the same time, 53 financial companies pay $\$ 5.3$ billion in penalties of the total of $\$ 5.6$ billion gathered by OFAC. This is $93.4 \%$ of the total (Fig. 4) compared to $6.6 \%$ paid by 152 persons in other sectors.

Fig. 4. Share of the Financial Sector in the Overall Payments to OFAC in 2009-2019

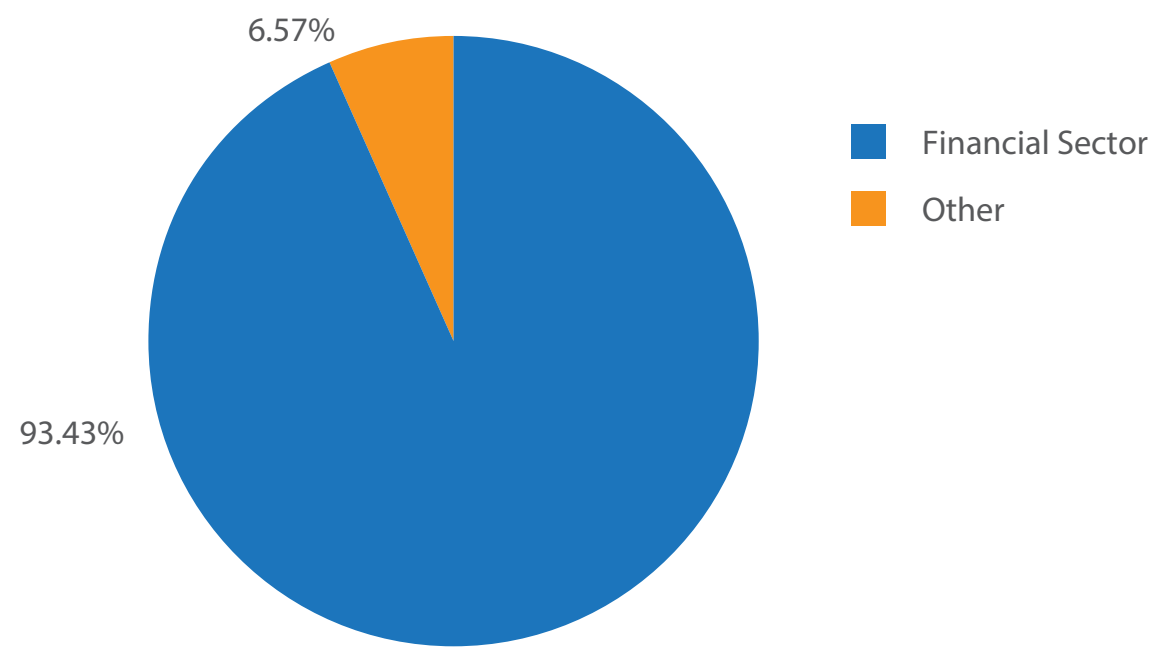

The financial sector represents another interesting skew. European banks are key contributors to OFAC's gains. I called it a "European paradox" and described it in my recent work (Timofeev, 2019). Of course, such distribution is hardly the result of deliberate discrimination of Europeans by the U.S. government. Banks make

Fig. 5. Number of Programs Violated by One Person

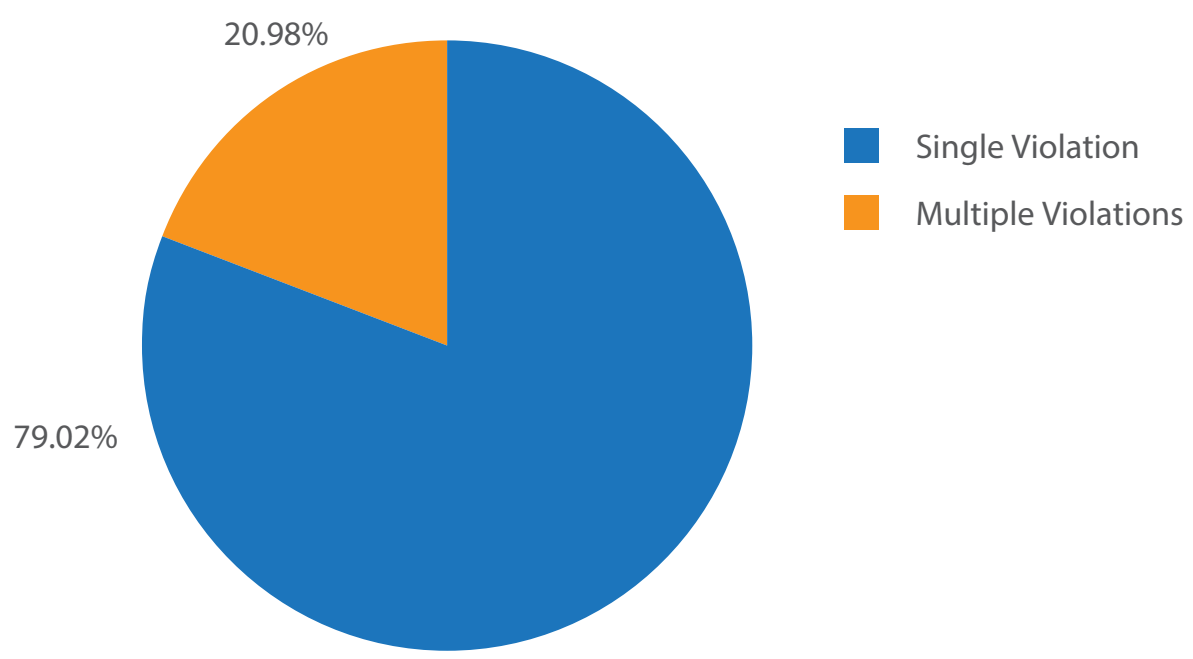


much more operations compared to other sectors and apparently are more likely to make mistakes or commit misconduct. The banks' vulnerability deserves a separate study.

Most persons under OFAC investigation violate only one sanctions program (79\%) (Fig. 5). In general, entities and individuals committed 312 violations in ten years. Iran is the most "popular" program violator: 107 cases out of 312 (Fig. 6). Cuba is the second one with 67. Such newest programs as the Ukrainian one accounts for only three violations. However, things may change in the future. The average duration of an investigation is 5.9 years. The mean value is presented in Fig. 6 with a median of six years. The longest duration is 14 years (starting with the year of the first violation and ending with a settlement agreement). The quickest took one year.

Fig. 6. Distribution of Program Violations

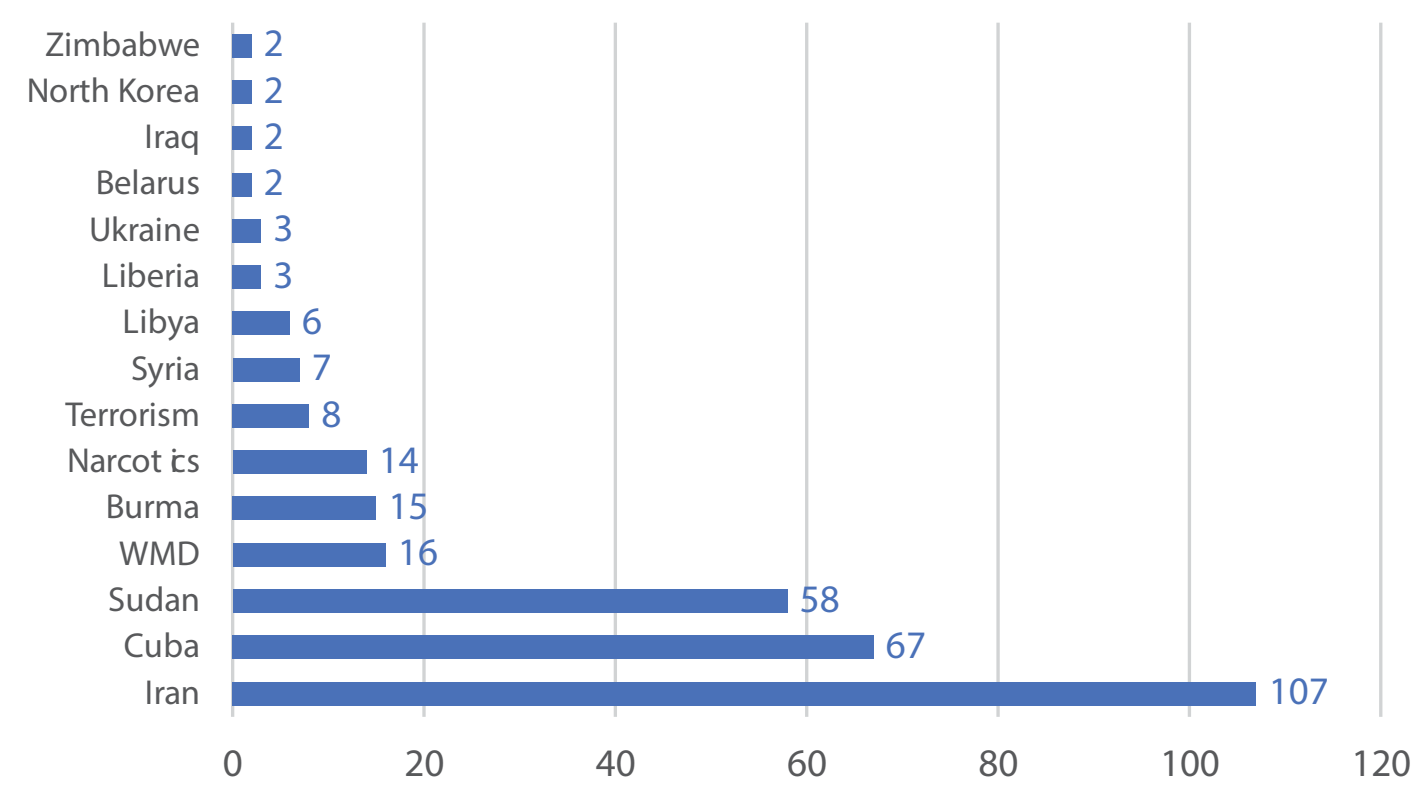

The average final penalty does not seem to be a representative indicator. The mean value is $\$ 27.8$ million, while the median is only $\$ 19,100$. This difference makes an average final payment a rather useless indicator. More interesting is the difference between base penalty and final penalty. In the majority of cases, final penalty is smaller than the base one. This will be important for testing the second hypothesis. 
The fact that OFAC makes discounts may mean that a business under investigation changes its behavior.

Last but not least for the introductory statistics is the fact that OFAC is the only regulator to run an investigation in 170 cases out of 205 (Fig. 7). In another 35 cases OFAC acted together with other regulators, such as the Department of Justice (22 cases), the Department of Commerce (13 cases), and the FRS Board of Governors (13 cases).

Fig. 7. Share of Cases Where OFAC Acted Alone or in Cooperation with Other Regulators

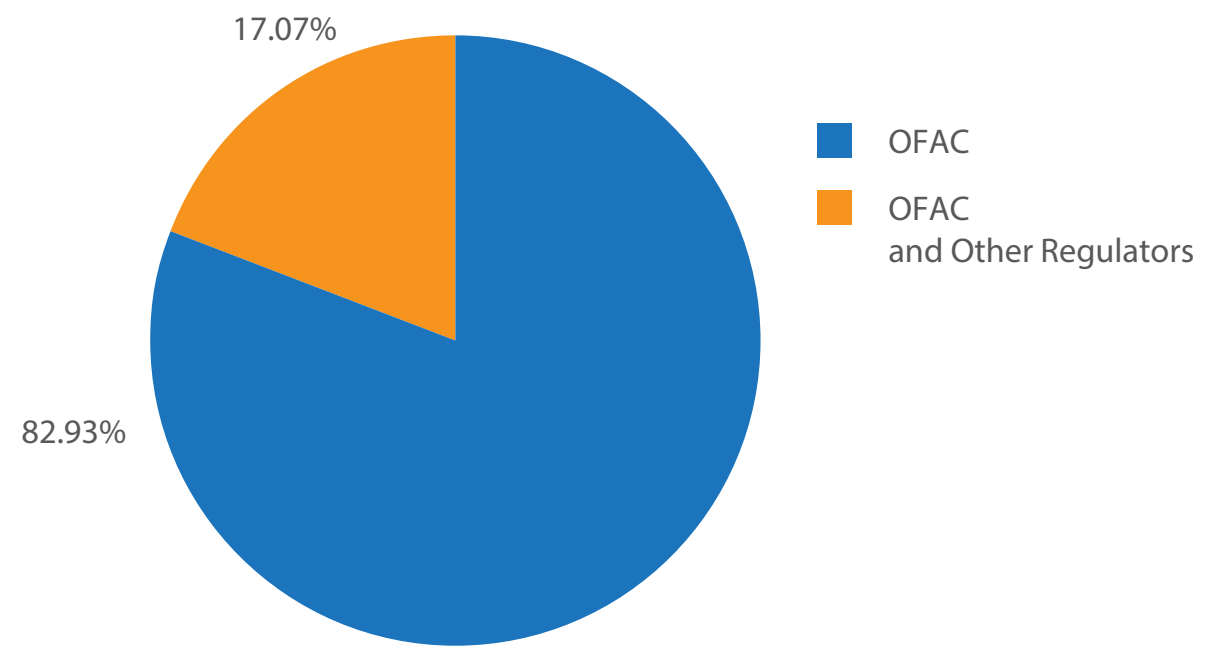

Fig. 8. Size of Business

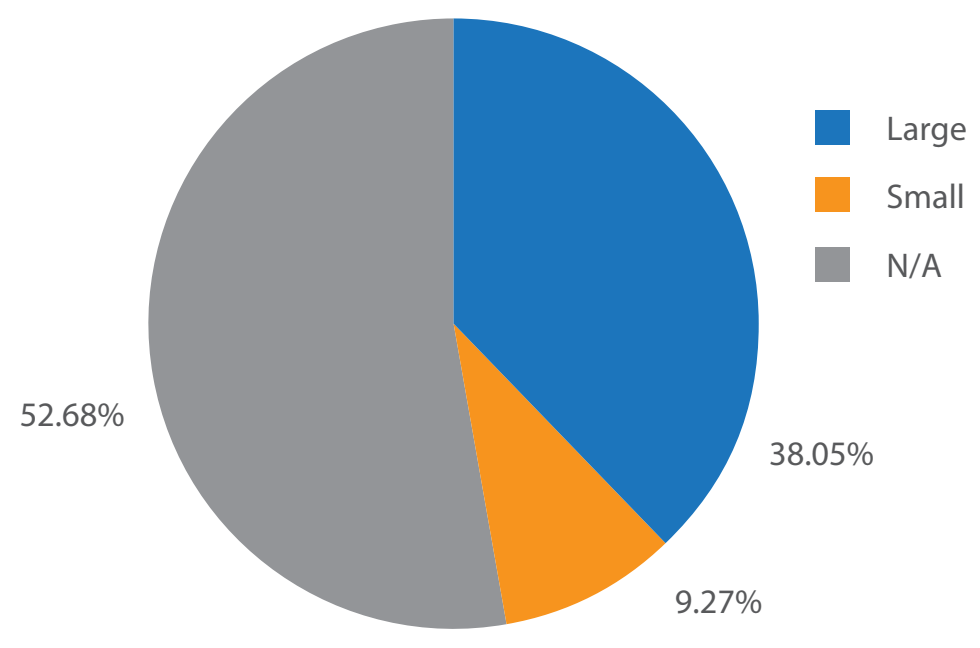

In terms of the size of companies (Figures 8-9), a majority of cases accounts for large (78) and sophisticated (81) companies, while 19 are small ones and 12 are not sophisticated. Other cases do not have an 


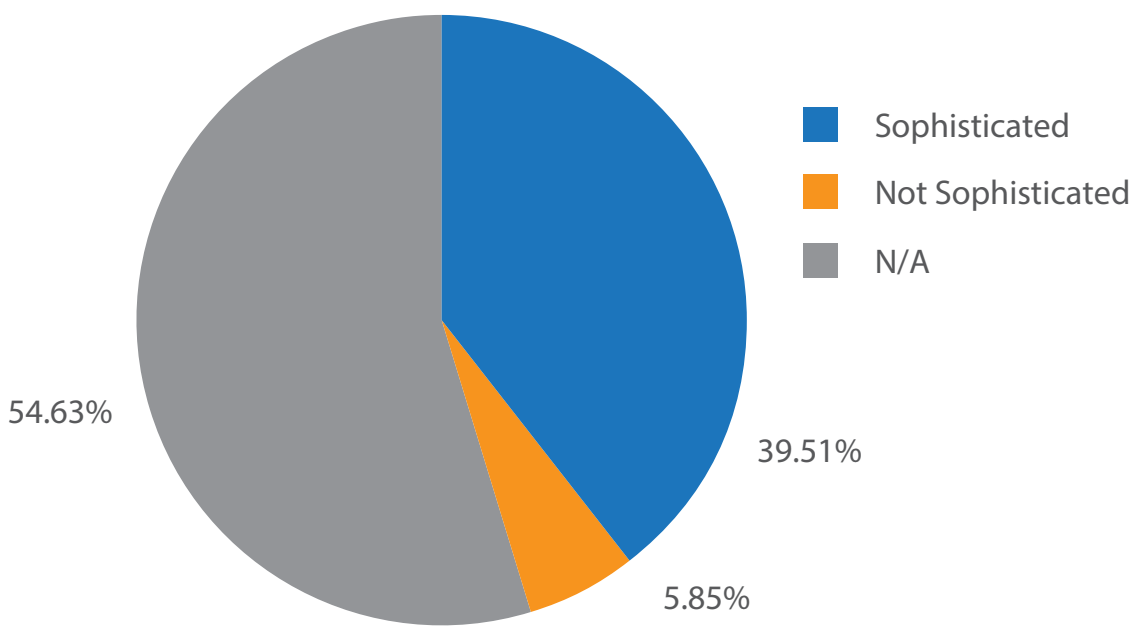

OFAC classification regarding their size or sophistication. Ten cases out of 205 account for individuals, and the other 195, for entities.

\section{TESTING HYPOTHESIS 1.}

The first important variable to test Hypothesis 1 is willfulness of a person's behavior to violate sanctions program. OFAC classified 32 of 205 cases as a willful violation, which accounts for $16 \%$ of all cases. Only in five cases OFAC assessed the behavior as unwilful. However, in most observations the cases were not classified, which may mean that OFAC does not consider willfulness to be the key factor in these cases. In other words, the share of willful violations is relatively small. On 14 occasions out of 32, willful violations went hand in hand with attempts to conceal them. In eight out of 32 violations a regular pattern of conduct was registered. On 19 occasions the senior management was aware of the violations. Thus, the data show that willful violations are usually not aggravated by attempts to conceal them, or by a regular conduct, or by involvement of senior managers. Still, such overlapping does occur, and these cases should be a matter of special research in the future. It is clear, however, that willful violations are usually of an egregious nature (22 of 32); only four of willful violations have been registered as non-egregious, and six are not classified. 
The analysis of reckless violations shows a different distribution. In 76 cases out of 205 reckless behavior was registered. On nine occasions the violations were both willful and reckless. Only 27 of 76 reckless violations are egregious, while 43 are non-egregious. This means that OFAC tends to assess reckless violations in a softer manner than willful ones. On 17 occasions out of 76 there was an attempt to conceal a reckless violation (this share is smaller than in the case of willful violations). The same is true about the regularity of the pattern of conduct (17 out of 76). At the same time, the senior management was aware of the violations in quite a considerable number of reckless violations: 41 out of 76 .

The adequacy of the compliance program prior to a violation is an interesting measure to compare willful and reckless violations. In general, the inadequacy of compliance is characteristic of a large portion of entities. OFAC classifies at least 86 cases out of 205 as inadequate in terms of compliance. Only nine cases are adequate. The remaining 110 cases are not classified. In 32 cases of willful violations 17 overlap with a fragile compliance program, while in the case of reckless violations 50 out of 76 indicate a similar problem. In other words, the data show that the inadequacy of the compliance program prior to violation is more characteristic of reckless rather than willful violations.

Another interesting measure to compare the two ways of behavior is voluntary self-disclosure of a violation by a company. In general, most of the persons under OFAC investigations do not disclose their violations voluntarily (132 cases out of 205). In 67 cases out of 205 there was a voluntary self-disclosure. Only 10 willful violations were disclosed volunarily, 20 were not, and two were not classified. In the case of reckless violations, 49 out of 76 cases were not disclosed volunarily, while 27 of out 76 cases were. In sum, both willful and reckless violations are usually not disclosed voluntarily.

The existing data do not provide enough evidence to support Hypothesis 1. Definitely, in some cases there is a rational (willful) plan to commit a violation, but the share of such occasions is small and accounts for only $16 \%$ of all cases. As for reckless violations, it 
is difficult to state whether they were rationally planned in advance. The fact that more than half of them (43 of 76) are non-egregious according to OFAC may mean that these violations are the result of inaccuracy, unintended actions, complex business environment, and other factors. In general, only 43 cases (willful, reckless, and other) out of 205 are egregious, while 106 are not, and the other 56 cases cannot be classified. The overall share of egregious cases is $21 \%$. This distribution rather disproves Hypothesis 1 than supports it. However, there is a relatively small share of companies which are clearly acting rationally to violate the rules.

It is difficult to say why both willful and reckless violators tend rather not to disclose their misconduct voluntarily. Clearly, there may be a rational reason for such a pattern of behavior. However, this may also be the result of unawareness. There is not enough data to identify the motivations, yet it is clear that a weak compliance program leads directly to higher vulnerability to violations, whether rational or not.

\section{TESTING HYPOTHESIS 2.}

To check the measure of compliance during OFAC investigations and afterwards three groups of variables were analyzed. The first one indicates whether individuals and entities cooperate with OFAC after their violations have become evident. In 144 cases out of 205 (70.2\%) there was at least one or more manifestations of cooperative efforts on the side of business. In 105 cases companies signed tolling agreements with OFAC. In 92 cases OFAC noticed that companies cooperated and promptly responded to the requests. Only eight companies failed to do so. In another 105 observations OFAC does not mention this, which means that it is not regarded as a mitigating factor (but it is not an aggravating one, either). On 43 occasions OFAC stated that companies had provided relevant information, and only in six cases OFAC officials specially pointed out that entities had failed to do so. In another 156 cases OFAC did not mention this factor either as mitigating or aggravating. These data show that companies tend to cooperate with OFAC during the investigation and that only a few of them fail to do so. The absence of OFAC assessments in many cases 
may mean that a person's behavior under investigation was at least not assessed as an aggravating factor.

The second group of variables includes measures taken by businesses to guarantee that violations will not occur in the future. In 132 cases out of $205(64.3 \%)$ companies took at least some measures to improve compliance with U.S. sanctions regimes. Only three entities failed to do so. In another 70 cases OFAC made no assessments, which means that this is not regarded as an aggravating factor. Settlement agreements contain information on specific measures to improve compliance. These data are incomplete. Apparently, OFAC has been more attentive to this information since 2018, and some data are available already for earlier cases. However, even the available data show some principal tendencies in companies' efforts to persuade OFAC that the risk of future violations is being treated seriously. In 32 cases compliance programs emerged from scratch as a remedial measure. In another 58 cases compliance programs were upgraded to a new level. Overall, there were 90 cases when compliance measures were devised or improved to meet OFAC requirements: eight companies initiated external audit of their compliance; seven companies conducted audit of their partner companies; four companies requested that their partners provide compliance procedures; 28 companies conducted personnel training; 13 companies installed new software to check transactions for sanctions risk; eight companies published manuals to educate their staff about sanctions; five companies fired employees responsible for sanctions violation; 15 companies hired additional compliance staff; and four companies increased sanctions compliance budgets. Although these data are incomplete and real remedial measures may be more extensive, they clearly indicate that remedial measures taken to avoid the risk of future violations is a regular and normal pattern of behavior.

The third kind of variables involves the history of violations. If OFAC enforcement actions against specific companies and individuals were ineffective, one would expect to observe cases emerging in the database several times. It is the policy of OFAC to regard the cases of new violations within five years after the previous one as an aggravating factor, while the absence of sanctions history for five years 
is considered a mitigating factor. According to OFAC data, in 162 cases sanctions history was not regarded as an aggravating factor and only in one case it was. The other 42 cases were not classified, which means that sanctions history is at least not treated as an aggravating factor. There are some companies which appear in the database several times; nine companies made settlement agreements with OFAC twice in ten years, but OFAC does not qualify this as an aggravating factor, taking into account the fact that the violations are more than five years apart. Repeated violations are rare.

In general, these data show that cooperation with OFAC changes the behavior of companies both during and after the investigation. Business tends to be more compliant with U.S. sanctions programs, as has been suggested by Hypothesis 2 .

\section{CONCLUSIONS AND DISCUSSION}

An attempt to study the efficiency of sanctions in terms of the "businesscentric" approach revealed a number of empirical observations. Firstly, there is no clear evidence that an intentional (rational) violation of sanctions is a widely spread pattern of conduct. At least this is true for 205 companies and individuals which faced an OFAC investigation in the past ten years. There are companies which violate rules willfully. However, much more violations result from reckless behavior. On many occasions recklessness is seemingly not the result of an initial strategy to decrease compliance costs, but rather comes from inaccuracy, unawareness, or poor compliance programs. Nonegregious violations prevail, which disproves the assumption about rationality as the main cause of violations. However, willful violations do occur and require a thorough case-study research. Apparently, the behavior of businesses which leads to violations differs from that of states. The latter may violate sanctions regulations for the sake of national or security interests, that is, they act more rationally than business which tends to act recklessly rather than willfully. These differences require further empirical verification.

Secondly, there is enough evidence that businesses significantly change their behavior during the investigation and afterwards. This is a 
regular pattern of behavior. It shows that OFAC measures are effective vis a vis business. Businesses' behavior is much different from that of states, as described in the literature. While targeted states often show commitment to the behavior which had led to sanctions, businesses rather show conformity and agreeableness. Non-conformism cases are exceptional.

These results, however, are still limited. First, the data on businesses cover only those of them which experienced OFAC investigations. There are far more companies that may change their intentions to violate the regulations, being threatened by an investigation or communicating with OFAC and other regulators in other ways. Also, the database presented in this study does not cover OFAC's SDNmeasures against violators, which could reveal different patterns of behavior.

There are some important methodological issues. The first and most acute one is the lack of information and a considerable amount of missing values. Future research could aim at a more sophisticated statistical analysis of the existing data. Also, it would be reasonable to study more profoundly the specific cases in qualitative terms.

\section{References}

Bapat, N.A., Heinrich, T., Kobayashi, Y. and Morgan, C., 2013. Determinants of Sanctions Effectiveness: Sensitivity Analysis Using New Data. International Interactions, 39 (1), pp. 79-98. DOI: 10.1080/03050629.2013.751298

Connolly, R., 2015. The Impact of EU Economic Sanctions on Russia. In: Dreyer, I. and Luengo-Cabrera, J. On Target? EU Sanctions as Security Policy Tools. Paris Institute for Security Studies, Report No. 25, pp. 29-38.

Connolly, R., 2018. Russia's Response to Sanctions. How Western Economic Statecraft Is Reshaping Political Economy in Russia. Cambridge: Cambridge University Press.

Cooper, Z. and Lorber, E., 2016. The Right Way to Sanction China. The National Interest, Vol. 142, March-April, pp. 36-42.

Crozet, M. and Hinz, J., 2016. Collateral Damage: The Impact of the Russia Sanctions on Sanctioning Countries Exports, CEPII Working Paper, June. 
Darsey, J. and Stulberg, A., 2019. Deaf Ears and the U.S.-EU-Russia Sanctions Tangle: Contending Strategic Discourses and Mutual Emboldenment. International Organizations Research Journal. Forthcoming.

Drezner, D., 1999. The Sanctions Paradox: Economic Statecraft and International Relations. New York: Cambridge University Press.

Drezner, D., 2015. Targeted Sanctions in a World of Global Finance. International Interactions, 41(4), pp. 755-764. DOI: 10.1080/03050629.2015.1041297

Early, B. and Preble, K., 2018. Enforcing Economic Sanctions: Analyzing How OFAC Punishes Violators of U.S. Sanctions. SSRN Papers [online]. Available at: $<$ https://papers.ssrn.com/sol3/papers.cfm?abstract_id=3306653> [Accessed 21 May 2019]

Economic Sanctions Enforcement Guidelines, 2009. Federal Register, 74 (2015), Monday, November 9. Available at: <https://www.treasury.gov/resource-center/ sanctions/Documents/fr74_57593.pdf> [Accessed 19 May 2019]

Fritsz, O, Christen, E., Sinabell, F., and Hinz, J., 2017. Russia's and the EU's Sanctions: Economic and Trade Effects, Compliance and the Way Forward. Brussels: Directorate-General for External Policies.

Giumelli, F., 2016. The Purposes of Targeted Sanctions. In: Beirsteker, T., Eckert, S. and Tourihno, M. (eds). Targeted Sanctions. The Impacts and Effectiveness of United Nations Action. New York: Cambridge University Press.

Graaf, T. van de, 2013. The "Oil Weapon" Reversed? Sanctions Against Iran and U.S.-EU Structural Power. Middle East Policy, 20(3), pp. 145-163.

Grauvogel J. and Soest Ch. Von, 2014. Claims to Legitimacy Count: Why Sanctions Fail to Instigate Democratization in Authoritarian Regimes. European Journal of Political Research, 53(4), pp. 635-653. DOI: 10.1111/1475-6765.12065

Hinz, J., 2017. The Cost of Sanctions: Estimating Lost Trade with Gravity. Kiel Working Paper, No. 2093, November.

Hufbauer, G., Shott, J., Elliott, K., 1990. Economic Sanctions Reconsidered: History and Current Policy. Second Edition. Washington DC: Peterson Institute for International Economics.

Hufbauer, G., Shott, J., Elliott, K., and Oegg, B., 2009. Economic Sanctions Reconsidered. Third Edition. Washington DC: Peterson Institute for International Economics.

Jaeger, M.D., 2018. Coercive Sanctions and International Conflicts. London and New York: Routledge. 
Jazairi, I., 2015. Report of the Special Rapporteur on the Negative Impact of Unilateral Coercive Measures on the Enjoyment of Human Rights. United Nations General Assembly Human Rights Council Thirty Session.

Jazairi, I., 2018. Report of the Special Rapporteur on the Negative Impact of Unilateral Coercive Measures on the Enjoyment of Human Rights on His Mission to the Syrian Arabic Republic. United Nations General Assembly Human Rights Council Thirty-Sixth Session.

Kaempfer, W. and Lowenberg, A.D., 2007. The Political Economy of Economic Sanctions. In: Sandler, T. and Hartley, K. (eds.) Handbook of Defense Economics, Vol. 2, Amsterdam: Elsevier.

Kholodilin, K., and Netsunaev, A., 2016. Crimea and Punishment: The Impact of Sanctions on Russian and European Economies. Berlin: German Institute of Economic Research, April 11.

Kholodilin, K and Netsunaev, A., 2017 Crimea and Punishment: The Impact of Sanctions on Russian and European Economies. Eesti Pank Working Papers, No. 5.

Kim, H., 2014 Stifled Growth and Added Suffering. Tensions Inherent in Sanctions Policies against North Korea. Critical Asian Studies, 46(1), pp. 91112.

Maloney, S., 2015. Sanctions and the Iranian Nuclear Deal: Silver Bullet or Blunt Object? Social Research, 82(4), pp. 887-911.

Marinov, N., Nili, Sh., 2014. Sanctions and Democracy. International Interactions, 41, pp. 765-778.

Moret, E., Giumelli, F. and Bastiat-Jarosz, D., 2017. Sanctions on Russia: Impacts and Economic Costs on the U.S. Geneva International Sanctions Network, March.

Nephew, R., 2018. The Art of Sanctions. A View from the Field. New York: Columbia University Press.

Neuenkirch, M. and Neumeier, F., 2015. The Impact of UN and U.S. Economic Sanctions on GDP Growth. European Journal of Political Economy, 40, pp. 110-125.

Pape, R.A., 1997. Why Economic Sanctions Do Not Work. International Security, 22(2), pp. 90-136.

Rosenberg, E., Goldman, Z., Drezner, D. and Solomon-Strauss, J., 2016. The New Tools of Economic Warfare. Effects and Effectiveness of Contemporary U.S. Financial Sanctions. Centre for a New American Security, April. 
Spadoni, P., 2010. Failed Sanctions: Why the U.S. Embargo Against Cuba Could Never Work. Gainesville: University Press of Florida.

Timofeev, I., 2019. Europe under the Fire from U.S. Secondary Sanctions. Valdai Club's Special Report for SPIEF-2019. Available at: <http://valdaiclub. com/a/reports/europe-under-fire/> [Accessed 25 May 2019]

Tourinho, M., 2015. Towards a World Police? The Implications of Individual Targeted Sanctions. International Affairs, 91(6), pp. 1399-1412.

Whang, T., 2011. Playing to the Home Crowd? Symbolic Use of Economic Sanctions in the United States. International Studies Quarterly, 55, pp. 787-801. Zarate, J., 2013. Treasury Wars. The Unleashing of a New Era of Financial Warfare. New York: Public Affairs. 


\title{
Unilateral Sanctions in a Multipolar World
}

\section{Challenges and Opportunities for Russia's Strategy}

\author{
Anastasia B. Likhacheva
}

\section{Abstract}

In the 1990s-2000s unilateral sanctions were viewed primarily as a reactive, often tactical, policy tool applied to weaker countries, or as an auxiliary strategic instrument (greatly inferior in importance to military-political ones). But today the status of sanctions has risen significantly. From a formal point of view, they are still ineffective since in most cases they do not lead to the achievement of declared political goals. However, in the past two to three years sectoral sanctions against Iranian and Russian companies and their partners, and technological ones against China (in addition to the trade war) have been expanded, which increasingly turns them from a "noisy" but ineffective tactical instrument into one of the pillars of strategic deterrence. This article examines three interrelated developments that have occurred in recent years: unilateral sanctions as such, their effects, both direct and concomitant (collateral damage), and, finally, reactions to them. Our analysis suggests that formal and

\footnotetext{
Anastasia B. Likhacheva, Ph.D. (Political Science)

National Research University-Higher School of Economics, Moscow, Russia

Faculty of World Economy and International Affairs

Associate Professor
}

SPIN RSCI: 5555-1336

ORCID: 0000-0001-6673-3096

ResearcherID: J-9043-2015

Scopus AuthorlD: 57205251880

Tel: $+7(495) 772-9590 * 22156$

E-mail: alikhacheva@hse.ru

Address: Office 427, Bldg.1, Malaya Ordynka Str. 17, Moscow, Russia 
informal unilateral sanctions will be intensified both in the short term and in the medium term of three to five years. However, within the next ten to fifteen years, as the international political and economic system becomes increasingly mosaicked, even their immediate effects and consequently their importance will be smoothed over, while the cost of international cooperation will increase. In other words, sanctions will become less ruinous, but fostering "fortress to fortress" bonds will become significantly more expensive and will require large investments in "building trust" with new partners. For Russia, this means transforming the strategy of survival under sanctions, launched five years ago, into a strategy of development under sanctions.

Keywords: unilateral sanctions, Russia, China, multipolarity, geo-economics

\section{INTRODUCTION}

The term 'sanctions' has become so widespread, and their use has expanded so much that one study can hardly cover all relevant trends pertaining to this phenomenon. So, the article focuses on formal unilateral sanctions understood herein as restrictive measures with economic effects, which pursue political objectives and are introduced in circumvention of the UN Security Council.

Thousands of unilateral sanctions are imposed every year against individuals, companies, NGOs, and less often against states, as formal measures initiated mainly by the United States and less often by the EU and other U.S. allies (Australia, New Zealand, Japan, etc.). In 2018 alone, the United States imposed sanctions against approximately 350 individuals, 300 entities, 49 vessels and 32 aircraft in addition to about 700 individuals and entities associated with Iran that were subjected to sanctions when the U.S. seceded from the JCPOA (Dentons, 2019).

There are also numerous informal restrictive measures actively used by countries, such as Russia and China, which do not recognize unilateral sanctions and consider the UN Security Council the only legitimate authority empowered to impose sanctions. But the most significant and visible changes are occurring in formal sanctions practices and their effects, because informal restrictive measures 
rely on traditional tools, mainly various non-tariff barriers in trade in goods and services like Russian measures against Georgian and Moldovan wine (Newnham, 2015) and Turkish tomatoes (Özertem, 2019), or China's sanctions against its neighbors (Reilly, 2012).

In this article we will focus on the evolution of formal unilateral sanctions in the post-bipolar period, unless stated otherwise. It is these sanctions that are used today against Russia and, gradually, against China. During the Cold War period (1945-1991), sanctions as an element of the "economic Cold War" were incorporated into the structure of bipolar confrontation and used against the Soviet Union and other socialist countries (through the Coordinating Committee for Multilateral Export Controls (COCOM)) as well as against China. Although in the post-bipolar period sanctions have not lost relevance in the foreign policies of the United States and other players, but on the contrary have gained greater importance, this kind of influence and, above all, the external conditions for its use have changed significantly.

The hypothesis of the study is that although the legal approaches to the use of sanctions in the United States and other countries, which impose formal unilateral restrictions, remain intact, changes in their nature and external conditions for their use require new responses to sanctions challenges.

The purpose of the study is thus to determine necessary qualities for the Russian strategy of responding to sanctions and related challenges as sanctions instruments and external conditions for their use keep changing quite rapidly.

Within the framework of this article, we will consistently solve three tasks: first, we will systematize key changes in sanctions policy as such; second, we will assess trends in reaction to such sanctions, and, accordingly, to qualitative changes in their effects. Finally, part three will focus on Russia's sanctions policy and assess its potential in the international context considered.

\section{EVOLUTION OF UNILATERAL SANCTIONS}

Sanctions represent an ever-changing phenomenon of international life. Even if sanctions are formally imposed in the same way as five or 
twenty-five years ago, there are a number of signs indicating that they have undergone fundamental changes.

\section{Stakeholders of Sanctions Agenda}

The most visible shift concerns the target audience, which has expanded significantly and become more privileged by international standards. Unlike in 2014, when the imposition of sanctions against Russia was considered an exceptional situation, today sanctions are more and more often viewed as a "new normal" of international relations.

In the 1990s, sanctions were used mainly against small countries with a view to changing their political regime or behavior in the international arena, or against international drug cartels (for example, the international campaign "La Lista Clinton," launched by the United States in 1995). In the early 2000s, a fierce sanctions war was started against a new player-international terrorist organizations (Hufbauer, Schott and Oegg, 2019)-by means of financial sanctions effected through the Financial Action Task Force (FATF) and the U.S. financial intelligence services' access to the SWIFT worldwide interbank financial telecommunication system (Zarate, 2016).

Sanctions were also imposed against great powers: India (for nuclear weapons) and China (after the events in Tiananmen Square), but the former were of limited severity, and the latter, imposed simultaneously by the United States and the EU, were subsequently lifted except for the arms embargo. These sanctions were primarily a disciplinary measure rather than a means of deterrence against a major power.

The first major player to face so-called all-out, or comprehensive, sanctions was Iran in 2010, but the tendency to make sanctions against that country global dates back to the 1990s. The new sanctions were initiated by the U.S. which had previously been imposing unilateral restrictions on Iran for more than 20 years. In the 2000s the grip was tightened further: the first UN Security Council resolution was adopted in 2006 (No. 1696), followed in the subsequent three years by four more: No. 1696, No. 1737, No. 1747, and No. 1929, the toughest one of which made the sanctions complete. Unilateral sanctions, including the severest ones, such as the disconnection from the SWIFT system, 
broadened their coverage, but it was only after the U.S. resolution that such a powerful and effective anti-Iranian coalition was built (Timofeev, 2018b; Ji-Hyang and Lee, 2013).

Then, in 2014, sanctions were imposed on Russia, and over the following five years they have transformed from mainly the first "disciplinary" packages adopted in the spring of 2014 into systemic and deterrent ones. According to leading experts, the next great power to be subjected to the intense pressure of sanctions will be China (Drezner, 2018a). In fact, it has already been facing individual sanctions and an arms embargo since the 1990s. In part, Chinese companies fall under sanctions not for their "success" or market share, but for violating U.S. sanctions against Iran. That is how ZTE was slammed after repeated warnings of sanctions for the supply of prohibited equipment to Iran. Similar arguments were stated as the official reason for sanctions against Huawei, although the arrest of its top manager as part of these measures was quite unprecedented (The company's vice president and CEO's daughter was detained in Canada at the U.S. request) and only proved the political nature of the Huawei case (Bajak and Liedtke, 2019).

Second, the risks of so-called "secondary" sanctions for the EU, India, Korea, Japan, China and other countries have increased in recent years (Geranmayeh and Rapnouil, 2019). Some companies and banks in these countries, mainly European ones, regularly fall under American sanctions and have to pay fines for cooperation with sanctioned companies and countries. There are about 150 Chinese companies on the SDN lists. For other countries, the risk of getting on such lists may serve as a restrictive factor in making investment or trade decisions. Complaints about informal U.S. pressure have been repeatedly made at Chatham House Rule meetings by Korean and Japanese investors who are potentially interested in cooperation with Russia. A former OFAC employee, Juan Zarate, writes openly about this exhortative practice with regard to Iran (Zarate, 2016). However, it would be an exaggeration to say that such risks are a universal constraint for business. In the absence of UN Security Council resolutions, dozens of European, Korean, Chinese, and Indian 
corporations worked in Iran in the 2000s, and the American ban on Iranian oil import is violated nowadays, too (Singhi, Wong, and $\mathrm{Lu}$, 2019). A vivid example is the Nord Stream-2 project, in which Russia is the political target of sanctions, but any company that directly contributes to its implementation, i.e. European participants, may face sanctions as well.

Third, in the last two to three years, the number of countries using formal sanctions has increased. Apart from traditional sanctioning powers - the United States and the European Union-sanctions have become more widespread in the Middle East, largely due to Saudi Arabia's policy (Cordesman and Hashim, 2018): it has persuaded four Arab countries to impose sanctions on Qatar, and used individual sanctions against Canada (Drezner, 2018). In other words, we are witnessing the proliferation of formal sanctions, even though earlier formal sanctions were an exclusive foreign policy tool designed mainly to ensure the unavoidability of punishment, which could be done, at least partly, only by global actors.

\section{Sanctions Toolkit}

During this period, the sanctions toolkit has also changed to include a wider range of measures. Traditional trade sanctions, which have been in existence since $5 \mathrm{BC}$, have changed in two principal ways. First, there has been a shift from comprehensive sanctions aimed at blockading individual countries to so-called targeted, or "smart sanctions" (Drezner, 2011). It is worth mentioning that the new model of sanctions began to be used only after comprehensive and subsequent sanctions against Iraq (authorized by a UN Security Council resolution) had resulted in the death of several hundred thousand people from hunger (Koc, Jernigan and Das, 2007; Alnasrawi, 2001). Such blockades were considered inhumane (Kozal, 2019), so they had to be abandoned in favor of targeted sanctions against companies or individuals. Damage from such sanctions can be either symbolic (for example, the freezing of U.S. dollar assets or denial of entry to individual politicians and civil servants) or comparable with the damage from comprehensive sanctions, if, for example, the central bank of a particular state is 
disconnected from the SWIFT system (Totensen and Bull, 2002; Biersteker et al., 2018). Just like comprehensive sanctions, sudden isolation of a country from international financial flows directly affects the quality of people's life, but the concept has not been renamed. However, the effectiveness of such sanctions depends on the type of political regime against which they are directed. It is believed that authoritarian regimes are more resistant to comprehensive sanctions, while democratic regimes are more resilient against targeted sanctions (Major, 2012).

The second direction in which changes have taken place in the post-bipolar period shifted the focus from embargoes to financial and technological sanctions. The shift began during the Cold War, when Japan and Germany were the main states that helped third countries bypass the American trade embargo despite their own dependence on the U.S. economy, and intensified immensely after rapid globalization in the 1990s and 2000s (Hufbauer et al., 2007). At first, financial sanctions were used more and more often (to limit access to the American financial system and capital markets) (Hufbauer and Oegg, 2002), eventually followed by technological sanctions (sometimes in the form of financial restrictions but aimed at limiting access to technologies). While the former leave a window of opportunity for a gradual reorientation of capital markets, restrictions on the use of critical technologies almost certainly impede the development of a sanctioned country quite seriously and create strategic risks, as we can already see in the Russian oil and gas sector (Mitrova, Grushevenko and Malov, 2018). This indicates a gradual transition from sanctions as a disciplinary measure to sanctions as an instrument of deterrence.

The trend of recent years is the increasingly long-term nature of sanctions. This is borne out by the intensive codification of U.S. sanctions in the form of laws and persistent efforts by the legislative branch to snatch the sanctions agenda away from the executive branch just because it has been gaining more weight in U.S. domestic policy lately (Tama, 2019). The Congress previously passed sanctions acts against Libya, Iran (ILSA, ISA, etc.) and other countries, but their effectiveness was quite low. However, today the practice of sanctions 
legislation has changed. In 2017, the Congress legislatively codified presidential decrees that imposed sanctions on Russian companies and individuals, which makes them almost irrevocable. Such legislation is extremely inert, and even if the domestic political situation in the United States changes, one can hardly expect the anti-Russian or antiIranian restrictions adopted in the form of law to be lifted promptly. The best example is the Jackson-Vanik Amendment after the Soviet Union's breakup (Timofev, 2017).

Finally, the expansion of sanctions toolkit relies on the use of pseudo-universal systems and international institutions solely for the benefit of Western countries: SWIFT, dollar settlements and correspondent banks, international development institutions, Visa and Master Card payment systems. Until the 2010s, they were positioned as an international public good and did work effectively for the globalization of the international financial system. Yet, when necessary, they were immediately used as a political tool, starting with the disconnection of Iran from the SWIFT system. On the other hand, this became a powerful catalyst for third countries to start their search for alternative financial institutions.

One of the most significant novelties in the field of sanctions concerned not so much sanctions per se as the system of oversight over their enforcement. The U.S. Department of the Treasury suggested monitoring compliance with sanctions by strengthening oversight mechanisms through financial systems and their participants. So, the responsibility to watch compliance with sanctions requirements was transferred from the Office for Foreign Assets Control (OFAC) to individual American banks. Under the threat of heavy penalties (up to $\$ 8$ billion) or exclusion from the American financial system, the sanctions policy was actively outsourced to the private sector. This has been described in detail by one of its authors, Juan Zarate (Zarate, 2016). Supervision is carried out through the "financial compliance" of all persons interested in cooperating with the American financial system. New technologies capable of analyzing large amounts of data have undoubtedly played a big role in monitoring the enforcement of sanctions. In addition, informal criteria for the imposition of sanctions 
have been expanded: formal signs of circumvention of sanctions requirements, for example by means of bogus payments, are no longer necessary, as a company may be put on the sanctions list even on the basis of correspondence exposing its illegal activity.

\section{From Action to Mode of Action}

There is yet another change that has occurred in the sanctions agenda in recent years, which confirms that the nature of sanctions has gone from tactical to strategic: the deliberate strengthening of the unpredictability factor when "the mode of action" becomes more important than concrete actions themselves. While in the past the bargaining over sanctions boiled down to the terms of their lifting, now we can hear statements such as those by Kurt Volker: "We will impose new sanctions every one or two months" (Southfront.org, 2019), and see the Congress locked in fighting over "devilish bills" (Schroeder, 2018; Flatley and Weinstein, 2019; Mohsin and Wadhams, 2019).

Such practices fuel negative expectations among various stakeholders of international cooperation and result in the toxicity of jurisdiction as a whole rather than of specific individuals or entities. In other words, formal compliance with the policy of smart sanctions fulfils the goal of comprehensive sanctions. Such changes indicate a shift in the role of sanctions and their use for systemic deterrence.

\section{UNILATERAL SANCTIONS IN A MULTIPOLAR WORLD: PROSPECTS}

In general, there is a consensus on the issue of sanctions currently faced by both sanctioned countries and their partners who do not want to fall under secondary sanctions or reduce cooperation with the former. Moreover, the situation is complicated not only by the constantly growing number of specific sanctions and fines imposed for their violation, but also by increasing protectionist tendencies, which more and more often lead to open trade wars. Today one can identify a number of trends which will most likely determine the sanctions landscape in the medium term.

First, sanctions (aimed at achieving political objectives) are mixed with trade wars (aimed at obtaining economic benefits) due 
to increased competition among states in a less stable international environment (Timofeev, 2018a). This is not the first mixed "cocktail" in history: the embargo on Cuban sugar imports had a political nature, but American sugar producers welcomed it heartily. However such blending makes negotiation and deal-making much more difficult: this is true for both sanctions, because the conditions for lifting them are becoming increasingly unclear, and trade wars, because the most sensitive sanctions are justified by national security issues, but it is impossible to trade in national security.

This requires a sanctioned state to develop a proactive rather than reactive approach: a well-defined strategy of international cooperation with clear sanctions restrictions. Otherwise, it will be extremely difficult to reverse negative market expectations but, especially, to diversify partners and enter new markets.

As far as multilateral cooperation is concerned, it is likely to experience an ever-growing impact from sanctions. First of all, there are no global approaches and solutions to interstate disputes (SCO, RIC, BRICS could make some effort to fill this gap, but they have so far been trying to distance themselves from the issue of sanctions). Secondly, sanctions are becoming more prestigious and relatively cheap: the ability of a state to impose unilateral sanctions increases its status in the international arena. When Saudi Arabia imposes sanctions on Canada or Qatar, and a routine trade dispute between Uzbekistan and Ukraine is presented in the media as a risk of sanctions by Tashkent (Syundyukova, 2019), these events clearly show that sanctions are becoming a "new black color" in political fashion trends.

However, the international situation in five to ten years from now will be determined not only by the impact from sanctions, but also by the reaction to them, that is, by the countersanctions policy of many states. We will see more opportunities to make up for the negative effects of sanctions, in particular through integrated diversification of the international system:

- In the field of finance: capital markets will become more fragmented, new currency swaps will be used, and new payment instruments and systems will be created (Drezner, 
2015). Nevertheless, one can hardly expect the U.S. dollar to be replaced by anything else as a means of saving rather than settlement.

- In the field of technology: new solutions will be introduced for fast and cheap localization of production processes, new technological hubs will be created to minimize negative effects from technological sanctions, and more intermediaries will support value-added chains. In fact, while thirty years ago only Western countries possessed critical technologies, access to which could be limited by the U.S. or the EU, today Asian countries can also offer a number of important technological solutions. Naturally, no parity in this area can be expected even in the medium term, but some progress has already been made (for example, in the field of artificial intelligence, renewable energy, materials science, genetics and selection, etc.).

- In the field of trade: new trade routes will be actively developed, including the "Belt and Road" and the North-South international transport corridor, and new substitutes will appear for traditional goods, even in the energy sector. These measures will have an indirect effect on the ability to resist financial sanctions, but as China, India, Russia, and Iran diversify their trading partners, all countries, not just the sanctioned ones, will get more incentives to develop non-dollar settlements and create alternative insurance companies.

These approaches will directly affect the fallout from sanctions. In the medium term, there will be fewer "avalanche" effects from sanctions, less confidence in the international system and higher costs of developing international cooperation (Riker, 2017), at least because it will be more expensive to maintain multiple channels of international cooperation than in a homogeneous international environment.

Due to diversification, sanctions are increasingly less likely to have truly devastating effects on sanctioned economies (Smeets, 2019) (if they could ever have them without military support at all (Pape, 1997)), but their deterrent effect on development will continue to 
be quite tangible. In other words, today states are actively mastering survival strategies, but the preparation of development strategies under sanctions requires a deeper transformation of the established economic and political processes.

The constant risk of sanctions will continue to reduce trust and discourage countries from launching joint long-term projects even after sanctions are lifted. The case of Iran clearly demonstrates that it is difficult for "traitors" to return to the previously sanctioned markets, because local businesses have already reoriented themselves to cooperation with other countries (Blockmans, Ehteshami and Bahgat, 2016). The decline of trust itself necessitates higher costs, including those associated with the hedging of foreign exchange risks (for example, using many foreign exchange swaps instead of one global currency) and financial support for exports. For example, in 1979, the U.S. and European countries accounted for $77 \%$ of Iranian exports, primarily oil, and for $65 \%$ of imports, while Asian countries accounted for $29 \%$ and $20 \%$, respectively. In 2015, according to the International Trade Centre, Asia's share in Iran's exports exceeded 90\%, and the total volume of Iranian imports from Asian countries amounted to 68\%, which required the creation of a whole new infrastructure for trade with the new partners.

On the whole, under the influence of unilateral sanctions (but certainly not only them), the international system will become more dynamic, more mosaicked and more flexible.

For Russia and other sanctioned states, this has very clear implications for the development of international cooperation. On Russia's traditional arms and energy export markets, which are vulnerable to sanctions, most solutions can be found only through high-level political transactions and sanctions risk hedging strategies for specific organizations (non-use of the U.S. dollar, involvement of special intermediaries, creative structuring of transactions, etc.).

As for the consequences for Russia, China, India, and other countries, especially Iran, U.S. sanctions increase risks for joint projects in such areas as energy, infrastructure, and international transport corridors. There is a need for flexible and dynamic solutions that can 
be developed taking into account the current nature of sanctions. Such solutions should be dynamic, autonomous from American jurisdiction as much as possible, and accessible to small and medium-sized players.

First, it is impossible to find a permanent solution to counter sanctions in 2019 and keep it working for years: the logic of U.S. sanctions policy implies constant adjustment, both instrumental and technological, every year or two, on average, with a view to making the global financial system as a whole more transparent. Western restrictions against Iran have confirmed that harsh sanctions are dynamic and accelerating, as is the policy of countering them (all stages of stepping up American sanctions against Iran were studied in detail and systematized by Kenneth Katzman, while the tightening of compliance practices was described in Juan Zarate's book) (Katzman, 2019; Zarate, 2016). Otherwise, the negative effects of sanctions can wear out in a couple of years, and their continuation will be necessitated solely by the political situation, rather than by their objective effectiveness.

Second, the transition to national currencies in multilateral formats, such as Russia-Iran, India, China, opens the door to easier trade and currency balance adjustments. This is why it is essential to combine survival and development strategies when planning how to minimize the effects from sanctions.

Third, end-to-end solutions for small and medium-sized enterprises (SMEs) can be in demand in many countries. Strict requirements for risk management and sanctions compliance are too expensive for SMEs, and a certain "compliance package" sponsored by export support business associations can play a crucial role in driving their expectations. Otherwise, it will be easier for them to stay away from potentially toxic counterparties, or too costly to convince foreign partners that they are not "toxic."

Finally, the diversification of value-added chains with a large number of beneficiaries can ensure greater sustainability of projects, and the example of Nord Stream-2 convincingly proves this. If the project were purely Russian, the chances of blocking it would be much higher. 
This forecast is directly applicable to the Russian international strategy, more precisely to how it has been devised on the basis of the "antishock" therapy started in 2014.

\section{RUSSIA AND SANCTIONS CHALLENGES: EFFECTS AND REACTIONS}

It is generally believed that Russia's reaction to the sanctions was a "shock" response, but five years on we can talk about concrete strategies to counter outside pressure.

First, the main goal was to hold out (Mau, 2015): to avoid a financial and foreign trade collapse (which would have cut off the supply of food, medicines, dual-use goods, components and other important commodities), and isolation in international institutions which Russia considers important for itself. In economic terms, this was first reduced to import substitution (2014-2015) in a narrow interpretation of this term, meaning full substitution for all stages of production chains, which proved ineffective and unattainable, and localization (since 2016), meaning attraction of foreign technologies and industrial solutions for the production of goods in Russia. These measures were supported and financed by the federal budget. The weakest spot in this policy was small and medium-sized enterprises operating outside the military-industrial and export (essentially strategic) sectors of the economy (Connolly, 2018). They have suffered from restrictions on capital markets but have not yet received sufficient support even though a number of SME development measures have been adopted, including the SME Development Corporation, the SME Bank, and regional development institutions.

The second goal of the Russian economy was to intensify the diversification started earlier, in 2008-2009. It was then that some members of the Russian elite began to acknowledge the potential of cooperation with Asian countries, primarily China, which was showing double-digit growth rates, and spoke about the need to modernize the economy to fit in new markets, and increase the added value of Russian-made goods, etc. (Karaganov, 2009). However, as Jeffrey Mankoff points out in his study of Russia's Pivot to Asia, it was the sanctions that catalyzed this process and gave it an additional meaning 
for a wider circle of persons who make decisions concerning politics, business, and international military cooperation (Mankoff, 2015).

Today, there is no denying that the diversification of foreign economic relations is in progress: over the past five years Asia-14 (China, South Korea, Japan, India, and ASEAN countries) has taken 7\% of Russian trade away from European countries (hereinafter all foreign trade statistics are based on UNCTAD data, unless stated otherwise). With Central and South Asian and Middle Eastern countries, which now account for more than $50 \%$ of Russia's foreign trade turnover, this clearly shows that Greater Eurasia has turned from a political initiative announced in 2015 into a foreign trade model for Russia.

Just to compare, Iran needed fifteen years to restructure and redirect the first $10 \%$ of its trade turnover to Oriental countries: in 1979, Asian countries accounted for 29\% of Iran's exports and 20\% of its imports, but by 1995 their share had grown to $44 \%$ and $28 \%$, respectively, mainly at the expense of trade with the West.

Fig. 1. The Dynamics of Russia's Foreign Trade with the EU, Asia-14, and Other Countries in 2013-2018, in value terms

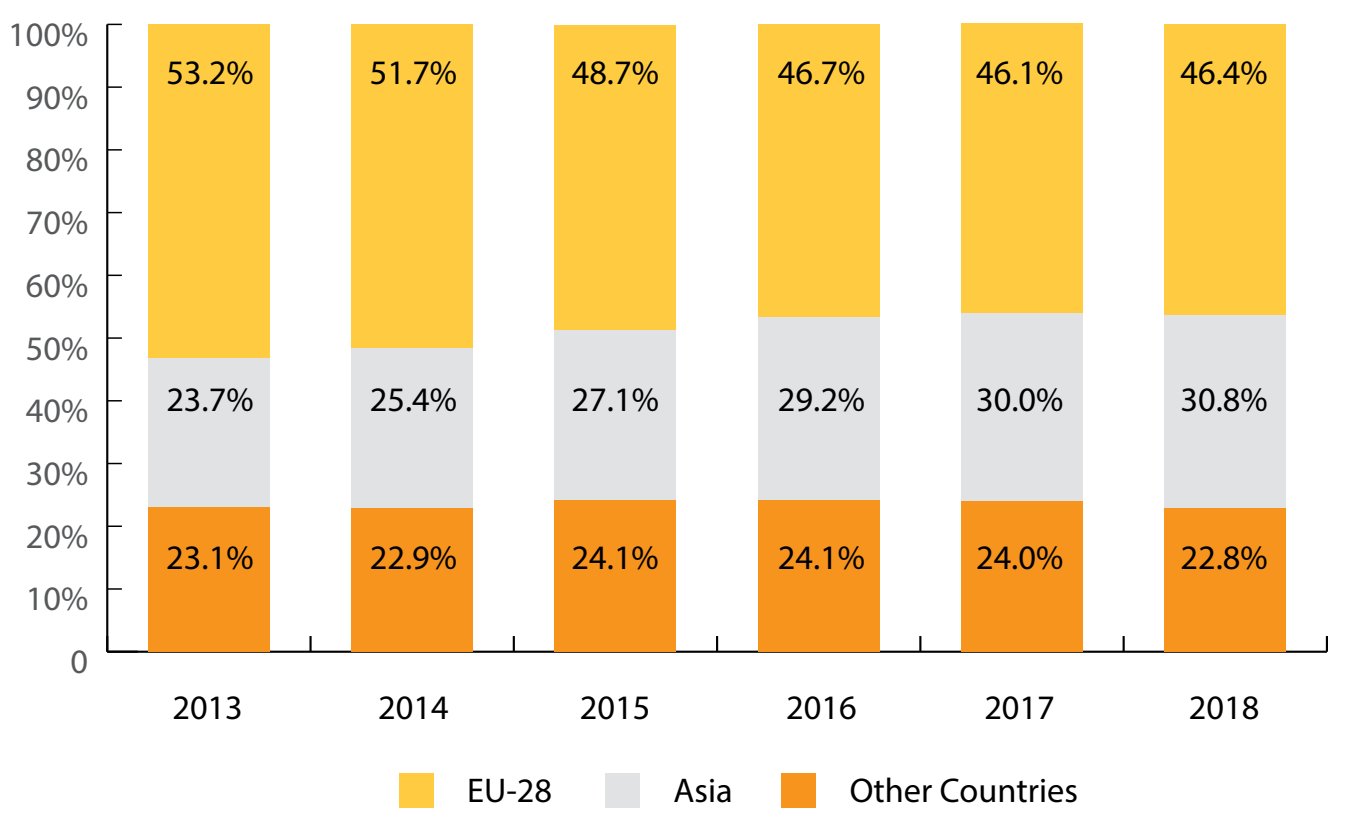

Source: UNCTAD

Currently, the immediate economic challenges for Russia posed by sanctions boil down to two major problems: payment risks due to 
the significant role of the U.S. dollar in the Russian economy and capital market restrictions-borrowing openly on Western markets is completely out of the question, it is difficult and costly on non-Western markets working with the American financial system, and almost impossible under investment programs that were used routinely before.

On the plus side, more countries become aware of the need to diversify their payment instruments since they are also vulnerable to American sanctions, which means more potential partners for Russia. External incentives for third countries to fight their dependence on the U.S. dollar include not only anti-Russian, but also anti-Iranian sanctions, U.S. trade wars, tangible risks of sanctions against major Chinese players, and "secondary" sanctions against European businesses.

With regard to payment options, the main instruments of diversification are national currencies and currency swaps linked to them, and regional payment systems, the development of which was announced in the EAEU and BRICS. Barter and quasi-barter deals (which have proved quite effective in the case of Iran (Early, 2015)) may certainly be useful for circumventing sanctions, but the scale of such operations is limited to a certain extent and requires harmonization of the interests of exporters and importers. Otherwise barter deals will not be effective. And because of this specificity, they remain a solution for big business.

Despite full political support in Russia and partner countries for initiatives to reduce the role of the U.S. dollar, the level of operationalization in the financial market remains quite low. But since this process is underway not only in Russia but also in other countries, the first results can be expected already in the medium term (RBC, 2018).

Still, the systemic obstacle to complete rejection of the U.S. dollar is that it is very difficult to find a replacement for its savings function, as opposed to the payment one. The economic and psychological readiness to save, for example, the euro, not to mention the yuan or rupees, is still quite low, while gold, which the Russian Central Bank has been actively acquiring lately, could provide reliable insurance for a rainy day, but is of little help to active investment operations. As a 
result, Russia’s foreign debt is at its all-time low since January 1, 2008 ( $\$ 483$ billion as of July 1,2019 ) and fully covered by the country's gold and foreign exchange reserves ( $\$ 518$ billion as of July 1, 2019), which significantly increases resilience to external shocks, but complicates the implementation of programs designed to accelerate economic growth.

In addition to monetary nuances, sectoral sanctions against Russian banks and oil and gas companies have made it extremely difficult to attract external financing (Karaganov, 2018): reorientation to new markets creates a time gap that could be fatal for business, and the sociocultural conservatism of business elites makes things even worse.

At the same time, business inertia, which manifested itself most acutely in 2014-2016, remains a sensitive issue. This trend is particularly noticeable in the financial sector where the situation in the 2000s and the early 2010s led European banks and funds to offer lending and loan refinancing and restructuring services to Russian companies. The need for an urgent adjustment to persuade previously unknown partners in China and other Asian countries that cooperation could be attractive for them presented not only investment, but also sociocultural difficulties for Russian business elites. This process is far from over, largely due to limited human ties and low support for Oriental studies in Russia, which is not the case in countries that have similarly intensive business relationships with China or India.

Of all possible sources of investment, which do not contradict either the logic of sanctions risk hedging, or Russia's real financial resources, or even the sociocultural traditions of doing business in Russia, the greatest potential is held by new development institutions, such as the Asian Infrastructure Investment Bank and the BRICS New Development Bank. Russia is the third largest founder in the former, and holds a $20 \%$ share in the latter, but has very few projects supported in either of them.

Summarizing the above, Russia has two main strategies to counter sanctions: a survival strategy and a development strategy. The survival strategy has so far proved more effective. The country's response in the field of security has been very systemic and addressed the biggest challenges: 
- A national interbank settlement system has been created in case the country is disconnected from SWIFT

- Hedging practices have been developed to secure transactions outside of U.S. control by stimulating settlements in national currencies

- A national payment system has been created in case Visa and Master Card stop servicing Russian users

- Investments have been made in Russian production facilities as protection from trade sanctions (value-added chains redirected to Russia), in particular, in the field of agriculture and certain pharmaceuticals

- Low external debt remains a priority

- The Central Bank continues buying up "Doomsday" assetsgold.

The development strategy, not so successful so far, given current international tendencies, is based on three basic principles: flexibility, diversification and openness.

The first principle-flexibility-implies engagement in new institutions (AIIB and BRICS, which Russia is actively doing), integration into new value-added chains, including inside the EAEU, the priority of which was announced in presidential decree in May 2018, and measures to make the Russian economy more dynamic (which has not been achieved yet).

The main challenges here are related to sanctions indirectly. First, it is a business culture that is not sufficiently plastic in Russia; second, it is the balance between the state and business in the economy: in all examples of successful development under sanctions in major countries, such as China or Iran, priority was given to business as a more flexible player. But since access to external capital markets is limited, practically the only available source of financing today (directly or indirectly) is the state, which does not make it possible to task business with increasing the flexibility of the Russian economy.

The second task is diversification. The main challenges here are again internal: there is still no full determination to work with Asia 
in the long term. The main indicator of such determination will be the interest of business in carrying out specific educational programs necessary for successful work with Asian partners. However, Oriental studies curricula have not been revised and updated on a systemic basis either in higher or additional education institutions. Isolated programs are launched occasionally, but, in general, the level of knowledge about modern economic realities in Asia falls far behind not only that of American experts, but also of their Canadian, Australian, and European counterparts (Karaganov, 2018).

The third, somewhat paradoxical, principle of development strategy amid the global rise of protectionism is openness. This strategy requires active participation in free trade zones and acceleration of integration projects to "multiply ties," rather than barricading oneself in a fortified fortress.

The main challenges here also stem from domestic factors rather than external sanctions: Russia's conservative trade policy (until 2014 FTA agreements were rarely considered relevant, and a FTA with China, which has them with ASEAN countries, Korea, Australia, and even New Zealand, is still nearly taboo); backpedaling of Eurasian integration (which is going through a natural struggle of sovereignties); and a lack of interest among businesses in the development of new external relations (largely due to previously uncompetitive export support conditions for non-resource sectors-the Russian Export Center's and Roseximbank's activities are only getting underway, while such institutions in competing countries have been working successfully for decades).

So, despite modest results, the reason for optimism about the development strategy is that its main constraints are not so much external as internal. No matter how much the sanctions may be intensified, Russia still has extensive domestic resources for making its development policy more effective and productive.

In conclusion, as a systemic element of the international agenda, sanctions will stay there for decades because they reflect fundamental transformations in international spheres of influence. This factor should be taken into account when adopting state and interstate decisions, adjusting business strategies, and introducing and 
promoting new legal practices. Otherwise, sanctions designed to be a means of deterrence may prove quite effective as such.

\section{References}

Alnasrawi, A., 2001. Iraq: Economic Sanctions and Consequences, 1990-2000. Third World Quarterly, 22(2), pp. 205-218.

Bajak, F. and Liedtke, M., 2019. AP Explains: US Sanctions on Huawei Bite, But Who Gets Hurt? [online] Available at: https://www.citynews1130. com/2019/05/21/ap-explains-us-sanctions-on-huawei-bite-but-who-getshurt-2/ [Accessed 13 Aug. 2019].

Biersteker, T. et al., 2018. UN Targeted Sanctions Datasets (1991-2013). Journal of Peace Research, 55(3), pp. 404-412.

Blockmans, S., Ehteshami, A. and Bahgat, G., 2016. EU-Iran Relations after the Nuclear Deal. Brussels: CEPS.

Connolly, R., 2018. Russia's Response to Sanctions. Cambridge University Press.

Conolly, R., 2018. Russia's Response to Sanctions: How Western Sanctions Reshaped Political Economy in Russia. Russia in Global Affairs. Available at: https:// eng.globalaffairs.ru/valday/Russias-Response-to-Sanctions-How-Western-Sanctions-Reshaped-Political-Economy-in-Russia-19865 [Accessed 13 August 2019]. Cordesman, A. and Hashim, A., 2018. Iraq: Sanctions and Beyond. New York: Routledge.

Dentons. 2019. US Sanctions Year-in-Review. [online] Available at: https:// www.dentons.com/en/insights/alerts/2019/january/7/us-sanctions-year-inreview [Accessed 3 June 2019].

Drezner, D., 2011. Sanctions Sometimes Smart: Targeted Sanctions in Theory and Practice. International Studies Review, 13(1), pp. 96-108.

Drezner, D., 2015. Targeted Sanctions in a World of Global Finance. International Interactions, 41(4), pp. 755-764.

Drezner, D., 2018a. Economic sanctions are about more than imposing costs. [online] Washington Post. Available at: https://www.washingtonpost.com/ news/posteverything/wp/2018/04/18/economic-sanctions-are-about-morethan-imposing-costs/?noredirect=on [Accessed 9 July 2019].

Drezner, D. 2018b. Why in the World Is Saudi Arabia Sanctioning Canada? [online] Washington Post. Available at: https://www.washingtonpost.com/ 
news/posteverything/wp/2018/08/07/why-in-the-world-is-saudi-arabiasanctioning-canada/ [Accessed 15 August 2019].

Early, B., 2015. Busted Sanctions. Stanford University Press.

Flatley, D. and Weinstein, A., 2019. House Democrats Restart Russia Sanctions Debate with Draft Bill. [online] Bloomberg, 15 May. Available at: https://www. bloomberg.com/news/articles/2019-05-15/house-democrats-restart-russiasanctions-debate-with-draft-bill [Accessed 18 Aug. 2019].

Geranmayeh, E. and Rapnouil, M., 2019. Meeting the Challenge of Secondary Sanctions. [online] Available at: https://www.ecfr.eu/publications/summary/ meeting_the_challenge_of_secondary_sanctions [Accessed 15 August 2019].

Hufbauer, G. and Oegg, B, 2002. Capital-Market Access: New Frontier in the Sanctions Debate. [online] PIIE. Available at: https://www.piie.com/ publications/policy-briefs/capital-market-access-new-frontier-sanctionsdebate [Accessed 16 August 2019].

Hufbauer, G., Schott, J. and Oegg, B., 2019. Using Sanctions to Fight Terrorism. [online] PIIE. Available at: https://www.piie.com/publications/policy-briefs/ using-sanctions-fight-terrorism [Accessed 17 July 2019].

Hufbauer, G., Schott, J., Elliott, K. and Oegg, B., 2007. Economic Sanctions Reconsidered. $3 r d$ ed. Washington, DC: Peterson Institute for International Economics.

Ji-Hyang, J. and Lee, P., 2013. Do Sanctions Work? The Iran Sanctions Regime and Its Implications for Korea. 1st ed. Seoul: The Asian Institute for Policy Studies.

Karaganov, S., ed., 2009. Towards the Great Ocean or New Globalization of Russia. Valdai Club Report. Available at: http://vid-1.rian.ru/ig/valdai/Toward_ great_ocean_eng.pdf [Accessed 13 August 2019].

Karaganov, S., ed., 2018. Towards the Great Ocean 6: People, History, Ideology, Education. Rediscovering the Identity. Valdai Club Report. Available at: http:// valdaiclub.com/a/reports/report-toward-the-great-ocean-6/ [Accessed 13 August 2019].

Katzman, K., 2019. Iran Sanctions. Congressional Research Service. [online] Fas.org. Available at: https://fas.org/sgp/crs/mideast/RS20871.pdf [Accessed 18 August 2019].

Koc, M., Jernigan, C. and Das, R., 2007. Food Security and Food Sovereignty in Iraq. Food, Culture \& Society, 10(2), pp. 317-348. 
Kozal, P. (2019). Is the Continues Use of Sanctions as Implemented against Iraq a Violation of International Human Rights? Denver Journal of International Law and Policy [online], 28(4), p. 383. Available at: https://www.questia. com/library/journal/1G1-75375990/is-the-continued-use-of-sanctions-asimplemented-against [Accessed 13 August 2019].

Major, S., 2012. Timing Is Everything: Economic Sanctions, Regime Type, and Domestic Instability. International Interactions, 38(1), pp. 79-110.

Mankoff, J., 2015. Russia's Asia Pivot: Confrontation or Cooperation? Asia Policy, 19(1), pp. 65-87.

Mau, V., 2015. Between Crises and Sanctions: Economic Policy of the Russian Federation. Post-Soviet Affairs, 32(4), pp. 350-377.

Mitrova, T., Grushevenko, E. and Malov, A., 2018. Perspectivy rossiskoy neftedobichy pod sanctsiami [Perspectives of Russian Oil Industry: Life under Sanction]. SKOLKOVO Energy Center. Available at: http://energy.skolkovo.ru/ downloads/documents/SEneC/research04-ru.pdf [Accessed 13 August 2019].

Mohsin, S. and Wadhams, N., 2019. U.S. Readying Russia Sanctions for U.K. Poison Attack, Sources Say. [online] Bloomberg, 29 March. Available at: https:// www.bloomberg.com/news/articles/2019-03-29/u-s-said-to-have-preparednew-russia-sanctions-for-u-k-attack [Accessed 19 August 2019].

Newnham, R., 2015. Georgia on My Mind? Russian Sanctions and the End of the 'Rose Revolution'. Journal of Eurasian Studies, 6(2), pp. 161-170.

Özertem, H., 2019. Turkey and Russia: A Fragile Friendship. Turkish Policy Quarterly, 15(4), pp. 121-134.

Pape, R., 1997. Why Economic Sanctions Do Not Work. International Security, 22(2), p. 90.

RBC, 2018. Siluanov raskryl detali plana po dedollarizatsii rossiyskoy ekonomiki [Siluanov Discloses Detailed plan on Dedollarization of the Russian Economy]. Available at: https://www.rbc.ru/economics/04/10/2018/5bb5c95f9a7947709e4 dac44 [Accessed 13 August 2019].

Reilly, J., 2012. China's Unilateral Sanctions. The Washington Quarterly, 35(4), pp.121-133.

Riker, W. H., 2017. The Nature of Trust. In: Social Power and Political Influence. Routledge, pp. 63-81.

Schroeder, P. (2018). Rubio and Graham Call for Stronger Russian Sanctions if the Kremlin Commits Election Interference Again. [online]. Business Insider. 
Available at: https://www.businessinsider.com/r-senators-push-sanctions-tosend-putin-message-on-election-interference-2018-7 [Accessed 18 August 2019].

Singhvi, A., Wong, E. and Lu, D., 2019. Defying U.S. Sanctions, China and Others Take Oil From 12 Iranian Tankers. [online] Available at: https://www. nytimes.com/interactive/2019/08/03/world/middleeast/us-iran-sanctionsships.html [Accessed 12 August 2019].

Smeets, M., 2019. Can Economic Sanctions Be Effective? [online] Available at: https://www.wto.org/english/res_e/reser_e/ersd201803_e.pdf [Accessed 18 August 2019].

Southfront, 2019. US to Impose New Sanctions on Russia Every 1-2 Months: Kurt Volker. Southfront, 18 October [online]. Available at: https://southfront. org/us-to-impose-new-sanctions-on-russia-every-1-2-months-kurt-volker/ [Accessed 19 August 2019].

Syundyukova, N., 2019. Uzbekistan Threatens Ukraine with Sanctions [online]. Available at: https://qazaqtimes.com/en/post/50500 [Accessed 18 August 2019].

Tama, J., 2019. Forcing the President's Hand: How the US Congress Shapes Foreign Policy through Sanctions Legislation. Foreign Policy Analysis. [online] Available at: https://academic.oup.com/fpa/advance-article-abstract/ doi/10.1093/fpa/orz018/5539839 [Accessed 10 April 2019].

Timofeev, I., 2017. Smart Policy: How Should Russia Respond to US Sanctions? [online] Valdai Club. Available at: http://valdaiclub.com/a/highlights/russiarespond-us-sanctions/ [Accessed 17 August 2019].

Timofeev, I., 2018a. Economic Sanctions as a Concept of Power Politics. MGIMO Review of International Relations, 2(59), pp. 26-42.

Timofeev, I., 2018b. Sankcii SShA protiv Irana: opyt primenenija i perspektivy razvitija [U.S. Sanctions against Iran: The Usage Experience and Perspective]. Polis: Political Studies, (4), pp. 56-71.

Tostensen, A. and Bull, B., 2002. Are Smart Sanctions Feasible? World Politics, 54(3), pp. 373-403.

Zarate, J., 2016. Treasury's War: The Unleashing of a New Era of Financial Warfare. New York: PublicAffairs. 


\title{
Flexible Coalitions: Origins and Prospects
}

\section{Permanent Alliances vs Ad Hoc Coalitions}

\author{
Konstantin V. Bogdanov
}

\section{Abstract}

The beginning of the 21 st century was marked by the growing popularity of the idea that flexible military-political coalitions built for concrete tactical tasks had certain advantages over long-term strategic alliances. This strategy was actively pursued on the international stage by the George W. Bush administration during its first term (largely owing to Defense Secretary Donald Rumsfeld's efforts) due to mounting contradictions caused by the transformation of the world order and the changing place and role of the United States in it. The U.S. gave up the concept of collective approval for external interference and stepped up unilateral actions. As existing collective security institutions become increasingly plagued with problems, flexible coalition strategies gain more popularity as evidenced not only by U.S. actions but also by those of Russia. While being an important element of the modern world order, which is currently in transition from a unipolar to a multipolar (polycentric) model, the strategy of flexible coalitions has its limits, the most important of which is their destructive impact on the development of

Konstantin V. Bogdanov, Ph.D. (Engineering)

Center for International Security, Primakov National Research Institute of World Economy and International Relations, Russian Academy of Sciences, Moscow, Russia

Research Fellow

ORCID: 0000-0002-5922-0791

SPIN RSCI: 7056-8209

E-mail: cbogdanov@imemo.ru

Address: 23 Profsoyuznaya Str., Moscow 117997, Russia.

DOI: $10.31278 / 1810-6374-2019-17-3-132-150$ 
international relations in the absence of all-encompassing collective security structures (global and/or bloc).

Keywords: U.S. unilateralism, unipolar moment, flexible coalitions, the Rumsfeld Doctrine, alliances in decline, multipolarity, multilateralism

The last fifteen to twenty years have passed amid heated debates on how to transform existing military-political alliances. One

of the most popular concepts discussed is flexible coalitions built for the implementation of concrete tasks by allies who may not necessarily be bound by permanent security agreements or deep interdependencies.

The hey-day of this concept is usually associated with U.S. Defense Secretary Donald Rumsfeld (2001-2006), who called for the adaptation of the U.S. foreign policy to the changed environment. However, the transformation of the U.S. military-political strategy, and especially that part of it which deals with coalitions, has proved more complex over the past thirty-five years than just an association with Donald Rumsfeld's name and his role in history. At the same time, the manifesto-like nature of the Rumsfeld Doctrine combined with the rapidly changing global military-political environment in the 2010s once again raise questions about the place of permanent multilateral alliances in the military strategy and foreign policy of the United States in the first place but also of other leading countries and how this role could change in the future. Can there appear a doctrine that will rest on the concept of flexible ad hoc coalitions which are constructive enough to strengthen international stability? Can this experience be used not only in the system of alliances built by the U.S. as a hegemon but elsewhere?

A military-political alliance is understood herein as a group of countries which are permanent (primarily peacetime) members of a military alliance based on the shared understanding of long-term security threats and complemented with a common vision of strategic 
development goals and often (but not necessarily) compatible values and ideologies rooted in the similarity of their sociopolitical and economic systems (institutional approach towards alliances close to the understanding of "historically established" and "natural" alliances as opposed to "tactical" ones, see Ghez, 2011). Major threats may include confrontation with another international actor (bloc) or a permanent diffused threat that requires security cooperation (terrorism, proliferation, international criminal networks, etc.). A flexible coalition is understood to mean a group of countries which is formed for addressing a concrete military-political task and may not necessarily share other frameworks; it is purposefully created for a short period of time and has a rigid and narrow interaction agenda ("project" approach towards alliances, see Silaev, Sushentsov, 2017). These definitions intentionally avoid the format of tactical but longterm coalitions based on broad cooperation, which dominate world history and are created for waging a major war between developed countries. The reason for this is that due to the specific features of the existing international security system, we will be talking here mainly about peacetime relations and a broad network of local conflicts.

The theory of international relations explores the nature, motives and dynamics of alliances (Morgenthau, 1960; Liska, 1962; Osgood, 1968; Holsti, Hopmann and Sullivan, 1973; Waltz, 1979; Walt, 1987; Mearshiemer, 2001) as well as differences between permanent peacetime alliances and tactical wartime coalitions (Snyder, 1990) quite thoroughly and from different angles. Modern researchers' views on changes in the nature and role of coalitions after the disintegration of the bipolar system differ and range from advocating permanent and binding alliances with complex interdependencies (SherwoodRandall, 2006) through a balanced and comprehensive assessment of objective advantages and disadvantages of flexible coalitions and their applicability in different scenarios (Haass, 1997; Cook, 2013) to questioning the benefits of permanent alliances at the current stage (Tertrais, 2004) and even claiming that a transition to flexible ad hoc coalitions is inevitable (Krauthammer, 2004). Russian researchers have also recently made attempts to analyze the reasons for the 
growing popularity of flexible coalitions in the transitional system of international relations (see, for example: Silaev, Sushentsov, 2017; Istomin, 2019).

The advocates of permanent alliances appeal to complex multifactor interdependencies based on a common image of the future and view them as a stabilizing factor (which reduces geopolitical risks) in international relations. The supporters of flexible coalitions say that permanent peacetime alliances are a left-over from the rigid construct and ideological (values) confrontation of the bipolar world and cannot be used effectively anymore (because they would maximize geopolitical advantages).

Opinions about the importance and the future of ad hoc coalitions also differ. For example, Ashton Carter, who eventually became U.S. defense secretary, wrote in 2004 that such alliances could be regarded as "a desperate fallback" (Carter, 2004, p. 74). At the same time, a rather large group of researchers emphasizes radical changes in the nature of military-political alliances after the disintegration of the bipolar system, which drives demand for such coalitions (Tertrais, 2004).

However, in most cases current works focus on the advantages and disadvantages of permanent alliances and flexible coalitions and rarely address systemic issues. At the same time, while analyzing all aspects of flexible coalitions it is necessary to determine their place in the overall dynamics of structural trends, identify the reasons and conditions for their emergence, and assess the nature of their possible impact on the structure of international relations in the long term. A systemic and historical analysis of the evolution of views in the U.S., as a leading global superpower, regarding the formation of alliances, including the planning of external interference, will make it possible to assess the influence of prevailing forms of coalitions on the context of international relations.

\section{TRANSFORMATION OF AMERICAN EXTERNAL INTERFERENCE DOCTRINES IN 1985-2000}

It took the U.S. almost fifteen years to rethink the systemic trauma its military-political planning suffered in Vietnam. It started with 
President Richard Nixon's statement that with all external obligations remaining in effect, the U.S. would in the future require its allies facing a threat to get involved "on the ground" rather than wait for the arrival of American troops (Nixon, 1969). This statement launched the "Vietnamezation" of the conflict in South Vietnam, which ended with the withdrawal of more than 500,000 U.S. troops from the country over a span of four years.

The final turn in the views on interventionism was solidified in 1984 by then Defense Secretary Caspar Weinberger, who used the "all or nothing" principle to formulate the conditions for using American troops outside the country. These conditions included the use of American troops abroad solely for the protection of vital interests and only as a last resort; clear goals and objectives of their use; constant reassessment to make sure that the troops being deployed are enough to achieve these goals and objectives; and sufficient support for the operation from Congress and the general public inside the country (Weinberger, 1984).

These rules were later dovetailed to the coalition strategy by Colin Powell (Chairman of the Joint Chiefs of Staff in 1989-1993). When studying the conditions for U.S. interference not only for protecting vital national interests but also for implementing limited tasks, Powell saw the problem of securing foreign policy support for such operations. This led to a set of views (Weinberger-Powell Doctrine), which not only tightened systemic and purely military requirements for such operations-including the obligatory and clearly-stated exit strategy prior to the interference as well as overwhelming and unlimited military superiority - but also made obligatory broad international support one of the conditions for preparing such operations (Atkinson, 1993; Powell, 1995; Monten, Bennett, 2010).

The George H.W. Bush administration (1988-1992) had developed a solid consensus that major interference outside the unquestionable zone of U.S. influence should be backed by a strong international understanding or at least by the approval of key allies. The model of "a new world order" adopted by the U.S. administration envisaged the predominant use of collective (that is, consensus-based) international 
security mechanisms (Sloan, 1991). While the invasion of Panama in 1989 was unilateral, the operation in Iraq in 1991, carried out by a broad international coalition with the unconditional support of most countries, became a model for the implementation of such a strategy.

However, these views had to be revised more and more often because of radical changes occurring in the system of international relations. In early 1992, the U.S. press obtained draft amendments to the national defense strategy prepared by Deputy Secretary of Defense Paul Wolfowitz, which journalists immediately dubbed "Wolfowitz Doctrine" even though this 46-page document remained just a memorandum. It justified, quite straightforwardly, the U.S.'s right for unilateral interference and, most importantly, stressed the archaic nature of big and static military-political alliances which had to give way to tactical ad hoc coalitions under the patronage of the U.S.'s "special stabilizing role" (Tyler, 1992).

This document was disavowed by the George H.W. Bush administration, but the succeeding Clinton administration repeatedly invoked it, for example, by incorporating the principle of "counterproliferation" in military planning documents to justify forcible interventions (including unilateral ones) in order to stop the proliferation of weapons of mass destruction (Aspin, 1993).

The U.S. administration faced both internal and external challenges. The former included, among others, the Congressional power shift to Republicans in the fall of 1994, which made the White House's foreign policy pursuits a constant target for criticism, especially when the Clinton team at first sought cooperative action on the international stage.

External challenges stemmed from the growing gap between the objectives and possibilities of the United States as the only superpower in the "unipolar moment" and immediate practical results that could be obtained through existing alliances and collective security institutions. Radical changes in the external environment and external threats to the U.S. after the disintegration of the bipolar system could not but affect the U.S. approach towards outside interference and international support for it in coalition strategies, placing greater 
emphasis on unilateral actions as a natural response to "tensions" in previous collective structures.

The operation in Bosnia exposed substantial disagreements both among NATO allies and between NATO and the UN (Daalder, 1998). The air campaign against Yugoslavia in the spring of 1989 was carried out solely as NATO's, not UN's, interference, and yet was derisively dubbed "war by committee," thus reflecting the fact that the main battles were fought not in the skies over Belgrade but in the numerous conciliatory committees and working groups. Mismatching objectives and possibilities, on the one hand, and growing disagreements among allies (which had previously closed their ranks against the proSoviet bloc as a common enemy) and in heterogeneous international institutions, on the other hand, naturally pushed Washington towards revising its doctrines.

Eventually, the Clinton administration had to restate its foreign policy strategy to make it "multilateral when we can, unilateral when we must." However, despite all the difficulties and resistance it did its best to seek a broad international consensus (at least a formal one) wherever possible (Patrick, 2010, pp. 24-25). According to A. Bogaturov (1996), it was a period of "pluralistic unipolarity" when the U.S. pursued its leadership not all by itself but taking into account the interests of other G7 countries bound together by common values. Nevertheless the U.S's deviation from the Weinberger-Powell Doctrine became evident already back then: external interference did not aim to protect vital interests of the country; it was carried out inconsistently and strengthened the interventionist vector in the U.S. foreign policy.

So by the end of the 1990s, there had emerged a set of heterogonous factors in the U.S. that necessitated a revision of George H.W. Bush's legacy and reinforced the unilateral component of the American military-political strategy.

\section{COALITION OBJECTIVES: RISE AND FAILURES OF THE RUMSFELD DOCTRINE}

George W. Bush invited a whole group of right-wing statesmen (neoconservatives) -Dick Cheney, Donald Rumsfeld, Richard Perle, 
and abovementioned Paul Wolfowitz-who held unilateralist and interventionist views to join his team. Condoleezza Rice was not considered a neoconservative and advocated a moderately unilateralist approach. Donald Rumsfeld, who initiated an overhaul of the U.S. military organization to keep it in tune with changing forms of warfare, left a special legacy (Rayburn, Sobchak, 2019, pp. 9-11).

Rumsfeld suggested giving up long preparations for military campaigns with the massing of forces as the Weinberger-Powell Doctrine required. The end of the Cold War changed the nature of "typical" armed conflicts involving the U.S. and increased the need to fight irregular forces, combat terrorism, and use force to prevent the proliferation of weapons of mass destruction. Rumsfeld saw the solution in creating highly mobile units, giving a bigger role to special operations forces, and using high precision weapons from greater distances. Some of the Pentagon's long-term and technologically sophisticated programs, such as the Prompt Global Strike concept, have their roots in this doctrine. Interventions were supposed to be carried out as promptly as possible, without the required massing of forces. An operation had to begin even before all of the assigned forces were deployed, with each unit going into combat immediately upon arrival.

However, the first practical use of the Rumsfeld Doctrine produced controversial results. The operations in Iraq in 1991 and 2003 are usually regarded as the two opposites, which they essentially are in practically all respects: in goals and objectives, in the international preparation of the war, in the speed and scale of prewar deployment, in the balance of forces, and in the way the war was fought in the air and on the ground. Long-term results are no exception. The bulky multinational contingent deployed in 1990-1991 in the Gulf area scored a cheap victory, making rather modest military-strategic gains, but boosted the image of the American military, strengthened alliances, and inspired the nation. However, in 2003 after a rapid deployment another contingent which was only one-third of the previous one needed no more than five weeks to take over Iraq, but it burdened the White House with a long, unpopular and extremely costly guerrilla 
and terrorist war, which on top of it all drove a wedge between the U.S. and Great Britain, on the one hand, and between NATO's leading Western European members, on the other hand (Record, 2007, p. 87).

It is necessary to separate strategy from the immediate interests pursued in a concrete war. There are three aspects to the set of views usually ascribed to Donald Rumsfeld. The first one is the transformation of the U.S. military machine. For this reason alone the new doctrine can be considered a success despite all the failures in Iraq and the tide of criticism against its author. Previous views were rejected as irrelevant to the new nature of warfare: brief but at the same time lowintensity armed conflicts, predominantly contactless war involving the use of high-precision weapons, a multi-factor environment with a tangle of military and non-military aspects, high activity of nonstate actors (from transnational corporations to terrorist groups and private military companies), and faster adoption and implementation of decisions.

The second aspect is the perception of the coalition strategy as part of such warfare. It was described by Donald Rumsfeld in his memo to George W. Bush in September 2001: “The mission determines the coalition, and the coalition does not determine the mission" (Rumsfeld, 2011, p. 354). The call for a wider use of flexible coalitions was quite legitimate as it was necessitated by objective changes in the international situation. However, Rumsfeld acted in his usual manner, resorting to assertive radicalism as he spoke of "old Europe" opposing the war in Iraq, thus multiplying his country's problems within NATO. It must be said that it was the lack of flexibility and attention to political support from allies that prevented the U.S. from building a powerful coalition for the war in Iraq. This could be one of the reasons for its failure (Cook, 2013, p. 563), a failure all the more dramatic because the coalition mechanics plays a key role in the international legitimation of U.S. actions (Istomin, Baykov, 2019). This triggered the collapse of the "pluralistic unipolarity" which was gone completely by the end of the 2000s (Bogaturov, 2008, p. 7).

Finally, the third aspect, which is more noticeable than others but least important in our study, is the development and conclusion of the 
Iraqi campaign, of which Donald Rumsfeld was the driving force and one of the architects (and subsequently its administrative victim) as he sought to apply his views in practice in an aggressive way, using, on the one hand, his hawkish foreign policy views and, on the other hand, administrative tricks and pressure on his subordinates (Dyson, 2009; Rayburn, Sobchak, 2019, pp. 36-38).

As we can see, the George W. Bush administration which pursued the policy of aggressive unilateralism can be criticized for how exactly its foreign policy steps were undertaken on the international stage. The American academic community did this quite thoroughly and convincingly in the 2000s (Ikenberry, 2003; Byman, 2008; Mitchell, Massoud, 2009). But it is hard to question the objective set of problems that guided the White House's actions.

The following conclusions can be drawn from what was stated above:

- After the disintegration of the bipolar system the interventionist component of the U.S. foreign and military policy kept growing under the pressure of circumstances until the beginning of the 2000s when the George W. Bush administration made it a key pillar of its strategy;

- Donald Rumsfeld put this concept together by combining new views on what the U.S. military organization should be like with revised coalition strategies and growing emphasis on unilateralism;

- The war in Iraq and the crisis within NATO can be described as a failure of the George W. Bush administration and a personal fiasco of Donald Rumsfeld as a military-political leader in a fresh crisis he orchestrated himself, but all by themselves they cannot entirely negate the strategy that gives priority to flexible coalitions.

The drawn-out war in Iraq during George W. Bush's second term slightly softened unilateralist tendencies in American interventionism, forcing the administration to look for support abroad (SherwoodRandall, 2006, p. 9). The war in Iraq never became a NATO war even 
though it is hard to overestimate the role the campaign that unfolded simultaneously in Afghanistan played in strengthening the shaken interaction and mutual understanding inside NATO. In fact, NATO transcended its traditional geographical area of responsibility to adopt a global security agenda, thus acquiring new qualities (Morelli, Belkin, 2009, p. 29).

This course was continued by Barack Obama, especially during his first term, when he prioritized the need to improve his country's image abroad, strengthen previous alliances and reorient the U.S. proactive policy from the Middle East to the Asia-Pacific region, which, in turn, required building new alliances and revamping existing ones (Obama, 2007; Hallams, Schreer, 2012, p.319; Unger, 2016).

However, it was then that after the global financial crisis of 2007-2008, NATO's European members started to cut their defense expenditures from $8 \%$ in Germany and Great Britain to $21-36 \%$ in the Baltic states (Mölling, 2012). This was accompanied by fierce burden-sharing debates which reflected the growing disproportion in financial commitments made by the U.S. and other NATO countries (Rasmussen, 2011). These debates also highlighted contradictions within the alliance caused by critical assessments of its efficiency.

Despite a planned increase in NATO defense expenditures after 2014, the situation became worse after the election of Donald Trump who had questioned the alliance's worthiness even before he took office. The new president demanded that the allies increase their defense budgets at least to the agreed $2 \%$ of GDP or better still to $4 \%$ (MacAskill, Crerar, 2018). Trump's attitude towards his allies, which is already creating complications and reminiscent of the situation after the war in Iraq in 2003, clearly reveals attempts to shift the burden of hypothetical containment of Russia in Europe to the latter, thus freeing American resources for carrying out a more flexible policy of interference in other parts of the world.

\section{NEW TIMES AND NEW ALLIANCES}

In the 1990s, faced with a lack of crisis-resolution mechanisms during conflicts with other UN members and with the erosion of the 
"institutional deal" with Cold War-era allies, the U.S. administrations had two options to choose from. They could use time, authority and efforts to overhaul the international security system, which in this case could have obtained (but not necessarily, which was the risk) instruments and potential for ensuring prompt and effective stabilization during crises (Skidmore, 2005). But this would have required the U.S. to give up part of the privileges and possibilities it had received as the de factor winner of the Cold War and would have made any administration daring to take such a step (especially amid confrontation between the executive and legislative branches) vulnerable to internal political infighting. But in the long run this could have helped (with no guarantees, though) create an architecture of equal and equitable international security that would have benefitted all sides. But this scenario never came true.

Instead, the other option was chosen: to step up unilateralist ad hoc efforts, thus delaying the systemic problem of reforming collective security institutions. Essentially, this can be described as a "credit" security model: Washington used its resources and image as well as leading countries' goodwill (among NATO countries as well, as the George W. Bush and Donald Trump experiences prove) to temporarily alleviate current crises, thus leaving all the complications and mounting international tensions for the future administrations to deal with. Repeated discussion paralyses inside permanent coalition structures and international institutions further inspired the U.S. unilateralist policy and destroyed these alliances and institutions, while failing to produce an alternative collective value, except for the American leadership in the system of "imposed consensus." This can be viewed as a paradox of some sort, but the U.S. efforts to preserve its leadership in the "unipolar moment" deformed the system of international relations even more and called American leadership into question, thus laying the ground for the emergence of revisionist powers and a "post-unipolar" world order (regardless of what it will eventually look like).

This makes the transformation of military-political coalitions (not only American ones) inevitable. The crisis of institutions and 
regimes created in the bipolar era gradually led to their collapse (which is especially noticeable in the field of arms control), which, on the one hand, creates a dangerous situation in the world, and on the other hand, increases the need for flexible coalition strategies amid dwindling trust among key players and a shortage of common values.

Meanwhile, the American experience of building flexible coalitions is spreading. The Astana format would be a good example as it has brought together Iran and Turkey with their regional leadership ambitions, an alliance that otherwise would have been unstable in the long term. And yet, it is quite appropriate for addressing concrete issues in the Syria crisis within the framework of a rigid tactical agenda. Another complex and flexible coalition is the post-Soviet "nesting doll" construct made up of the EAEU, the Customs Union, the CSTO, and the Russia-Belarus Union State, with a focus on constant long-term integration, taking into account member countries' differing state of readiness for growing interdependence and coordination in various areas. Its overlapping with the current SCO agenda, including regional security issues, creates an additional dimension.

A somewhat similar construct can be found in American attempts to put new substance into the Quad-quadripartite security dialogue between the U.S., Australia, India, and Japan-which essentially is one of the core institutions for containing China's growing influence (Miller, 2018).

Also noteworthy is the U.S. activities with its allies in Southeast Asia to develop bilateral ties based on an individual agenda, an approach suitable particularly for concrete pairs of allied states. Particularly noticeable against this background is the policy of strengthening relations with former regional partners that were once engaged to contain "world communism" (Tertrais, 2004, p. 138). This work, however, has not always been going smoothly as evidenced by the Philippines' dual policy under President Rodrigo Duterte. The coordinated system of bilateral alliances (both regional and global) may in the future provide the institutional basis for building distributed multilateral flexible coalitions glued together through a major patron power (as some sort of alliance "hub"), which keeps 
the target framework and conducts "shuttle" coordination for solving concrete tasks.

The principles of flexible coalitions, which guided the U.S. war on terror, were further developed in the U.S.-led international coalition against ISIS in Syria and Iraq. It employed a hybrid approach whereby Washington's vigorous efforts to incentivize potential allies were combined with collective work within "umbrella structures," primarily NATO, which promoted mutual understanding and facilitated smoother planning and combat operations. A complex informal coalition built for the war in Libya in 2011 is the previous version of this approach. This was a war waged mainly by NATO's European member states, with the U.S. participation and close coordination with some of the Gulf monarchies which pursued their own militarypolitical interests in the Libyan conflict.

However, the constantly changing context of international relations complicates things. It is generally believed that the "unipolar moment" is temporary, as the author of this concept noted (Krauthammer, 1990), and presumably signifies a transition from a bipolar to a multipolar (polycentric) system. How will this transition affect flexible coalitions which have proved so efficient thus far? Andrei Kortunov (2019) believes that associations with previous multipolar balance of power eras (such as the Concert of Europe) are far-fetched. In the 20th century, the very nature of foreign policy changed, with values and ideology coming to the fore as more grassroots actors joined politics. The pragmatic "dance of coalitions," like that of 18th-19th century European monarchies, becomes less probably due to public pressure in democratic states and the inertia of mass propaganda (especially amid mounting populism in politics and increasingly coordinated activity of social groups in information society). This would also be highly improbable even if one overlooks the dominating U.S. militarystrategic and politico-economic weight, which cannot be evened out by any "multipolarity" and which by far exceeds that of the British Empire in the 19th century or of France in the 18th century.

This makes it necessary to problematize flexible coalitions as well. But what could be a permanent common framework for a group 
of such coalitions glued together either by the patron power or by composition? What are the peculiarities of relations between members of different coalitions, especially if both consider themselves key allies of the patron power? The erosion of permanent collective security institutions at a time when the global hegemon is growing weaker creates an atomized environment, which can easily turn into a new Cold War of all against all, thus wasting resources needed for building flexible coalitions. What gave major players the freedom of maneuver when the previous world order was in crisis may lay a time bomb under the emerging world order. Contrariwise, constructive existence of flexible coalitions will require an all-encompassing superstructure which can only be provided by a consensus-based international security system and/or restoration of the bloc system.

Therefore it would be more realistic to view the passion for flexible coalitions as an important but transient phenomenon inherent to a concrete transitional period. The actualization of this phenomenon, carried out among others by Donald Rumsfeld in the 2000s, gave leading players a convenient and flexible instrument for tactical alleviation of crises, which, however, like the American preoccupation with unilateralism, strategically corrodes the institutional space of international interaction rather than strengthens international security. If the world order is stabilized through a new kind of bipolarity or major renovation of the global collective security system, flexible coalitions will by all means be absorbed by these structures as a specific instrument of limited use.

As one of the constructive transformation scenarios, Andrei Kortunov (2019) names the principle of multilateralism, which takes into account the interests of all members of the collective security system through deeper interdependence and a new level of integration aimed at ensuring equal and equitable security. A similar view of stabilizing alliances reinforced by interdependence was earlier expressed by E. Sherwood-Randall (2006) who had analyzed a narrower problem of correlation between long-term American national security interests and different coalition strategies.

A shared vision of common threats could serve as the basis for common values at the initiate stage, even though there is no doubt that 
this would not be enough for long-term and sustainable existence of such a system. Such a broad framework will most certainly have room for flexible coalitions to solve concrete tasks. A close analogue would be major UN peacekeeping and peace-enforcement operations during the Cold War.

\section{References}

Aspin, L., 1993. Counterproliferation Initiative. Presidential Decision Directive PDD/NSC 18. Available at: <https://fas.org/irp/offdocs/pdd18.htm >. [Accessed 02 April 2019].

Atkinson, R., 1993. Crusade: The Untold Story of the Persian Gulf War. New York: Houghton Mifflin.

Bogaturov, A.D., 1996. Pliuralisticheskaia odnololiarnost' i interesy Rossii' [Pluralistic Multipolarity and Russia's Interests]. Svobodnaia Mysl' [Free Thought], No. 2, pp. 24-36.

Bogaturov, A.D., 2008. Kontrrevoliutsiia tsennostei i mezhdunarodnaia bezopasnost' [The Counterrevolution of Values and International Security]. Mezhdunarodnye protsessy [International Trends], Vol. 6, No. 2, pp. 4-15.

Byman, D., 2008. An Autopsy of the Iraq Debacle: Policy Failure or Bridge Too Far? Security Studies, Vol. 17, No. 4, pp. 599-643.

Carter, A., 2004. How to Counter WMD. Foreign Affairs, Vol. 83, No. 5, pp. 72-85.

Cook, J., 2013. Military Alliances in the 21st Century: Still Relevant after All These Years? Orbis, Vol. 57, No. 4, pp. 559-573.

Daalder, I., 1998. Decision to Intervene: How the War in Bosnia Ended. Foreign Service Journal, Vol. 75, No. 12, pp. 24-31.

Dyson, S., 2009. 'Stuff Happens': Donald Rumsfeld and the Iraq War. Foreign Policy Analysis, Vol. 5, No. 4, pp. 327-347.

Ghez, J., 2011. Alliances in the 21st Century: Implications for the US-European partnership. Santa-Monica, CA: RAND Corporation.

Haass, R., 1997. The Reluctant Sheriff: The United States After the Cold War. New York: Council of Foreign Relations.

Hallams, E. and Schreer, B., 2012. Towards a 'Post-American' Alliance? NATO Burden-Sharing after Libya. International Affairs, Vol. 88, No. 2, pp. 313-327. 
Holsti, O. R., Hopmann, P. T., and Sullivan, J. D., 1973. Unity and Disintegration in International Alliances: Comparative Studies. New York: Wiley.

Ikenberry, G.J., 2003. Is American Multilateralism in Decline? Perspectives on Politics, Vol. 1, No. 3, pp. 533-550.

Istomin, I., 2019. The Logic of Counterpoint. Russia in Global Affairs, Vol. 17, No. 2, pp. 8-34.

Istomin, I. and Baykov, A., 2019. Dinamika mezhdunarodnykh al'yansov $\mathrm{v}$ neravnovesnoi mirovoi sisteme [Dynamics of International Alliances in an Unbalanced World Structure]. Mirovaya ekonomika i mezhdunarodnye otnosheniya [World Economy and International Relations], Vol. 63, No. 1, pp. 34-48.

Kortunov, A.V., 2019. Between Polycentrism and Bipolarity. Russia in Global Affairs, Vol. 17, No. 1, pp. 10-51.

Krauthammer, C., 1990. The Unipolar Moment. Foreign Affairs, Vol. 70, No. 1, pp. 23-33.

Krauthammer, C., 2004. A Farewell to Allies. Time [online]. Available at: $<$ http://content.time.com/time/magazine/article/0,9171,570253,00.html> [Accessed 02 April 2019].

Liska, G., 1962. Nations in Alliance: The Limits of Interdependence. Baltimore: John Hopkins University Press.

MacAskill, E. and Crerar, P., 2018. Donald Trump Tells NATO Allies to Spend $4 \%$ of GDP on Defence. The Guardian. [online] Available at: <https://www. theguardian.com/world/2018/jul/11/donald-trump-tells-nato-allies-to-spend4-of-gdp-on-defence> [Accessed 02 April 2019].

Mearsheimer, J.J., 2001. The Tragedy of Great Power Politics. New York: W.W. Norton.

Miller, J.B., 2018. The Quad: Security Cooperation between the US, Japan, India and Australia. Indo-Pacific Insight Series, Vol. 11. Crawley: Perth US-Asia Centre.

Mitchell, D. and Massoud, T., 2009. Anatomy of Failure: Bush's DecisionMaking Process and the Iraq War. Foreign Policy Analysis, Vol. 5, No. 3, pp. 265-286.

Monten, J. and Bennett, A., 2010. Models of Crisis Decision Making and the 1990-91 Gulf War. Security Studies, Vol. 19, No. 3, pp. 486-520.

Morelli, V. and Belkin, P., 2009. NATO in Afghanistan: A Test of the Transatlantic Alliance. Washington, DC: Congressional Research Service. 
Morgenthau, H.J., 1960. The Purpose of American Politics. New York: Knopf. Mölling, C., 2012. Trends Within the European Union. In: O’Donnel, C.M., ed., 2010. The Implications of Military Spending Cuts for NATO's Largest Members. Washington, DC: Brookings, pp. 6-9.

Nixon, R., 1969. The Great Silent Majority (Vietnamization Speech). [online] American History from Revolution to Reconstruction and Beyond. Available at: <http://www.let.rug.nl/usa/presidents/richard-milhous-nixon/ vietnamization-speech-1969.php> [Accessed 02 April 2019].

Obama, B., 2007. Renewing American Leadership. Foreign Affairs, Vol. 86, No. 4, pp. 2-16.

Osgood, R.E., 1968. Alliances and American Foreign Policy. Baltimore: John Hopkins University Press.

Patrick, S., 2010. 'The Mission Determines the Coalition': The United States and Multilateral Cooperation after 9/11. In: Jones, B., Forman, S. and Gowan, R., eds., 2010. Cooperating for Peace and Security: Evolving Institutions and Arrangements in a Context of Changing U.S. Security Policy. Cambridge: Cambridge University Press, pp. 20-44.

Powell, C., 1995. My American Journey. New York: Random House.

Rasmussen, A.F., 2011. NATO After Libya: The Atlantic Alliance in Austere Times. Foreign Affairs, Vol. 90, No. 4, pp. 2-6.

Rayburn, J. and Sobchak, F., eds., 2019. The U.S. Army in the Iraq War. Volume 1: Invasion - Insurgency - Civil War. 2003-2006. Carlisle Barrack, PA: U.S. Army War College Press.

Record, J., 2007. Back to the Weinberger-Powell Doctrine?'Strategic Studies Quarterly, Vol. 1, No. 1, pp. 79-95.

Rumsfeld, D., 2011. Known and Unknown: A Memoir. New York: Sentinel.

Sherwood-Randall, E., 2006. Alliances and American National Security. Carlisle Barrack, PA: Strategic Studies Institute, U.S. Army War College Press.

Silaev, N. and Sushentsov, A., 2017. Soyuzniki Rossii i geopoliticheskii frontir v Evrazii [Russia's Allies and the Geopolitical Frontier in Eurasia]. Valdai Papers, No. 66, April 2017.

Skidmore, D., 2005. Understanding the Unilateralist Turn in U.S. Foreign Policy. Foreign Policy Analysis, Vol. 1, No. 2, pp. 207-228.

Sloan, S., 1991. The U.S. Role in a New World Order: Prospects for George Bush's Global Vision. Washington, DC: Congressional Research Service. 
Snyder, G., 1990. Alliance Theory: A Neorealist First Cut. Journal of International Affairs, Vol. 44, No. 1, pp. 103-123.

Tertrais, B., 2004. The Changing Nature of Military Alliances. The Washington Quarterly, Vol. 27, No. 2, pp. 135-150.

Tyler, P., 1992. U.S. Strategy Plan Calls for Insuring No Rivals Develop. The New York Times. [online] Available at: <https://www.nytimes.com/1992/03/08/ world/us-strategy-plan-calls-for-insuring-no-rivals-develop.html> [Accessed 02 April 2019]

Unger, D., 2016. The Foreign Policy Legacy of Barack Obama. The International Spectator, Vol. 51, No. 4, pp. 1-16.

Walt, S.M., 1987. The Origins of Alliances. Ithaca, NY: Cornell University Press. Waltz, K.N., 1979. Theory of International Politics. Reading, MA: AddisonWesley.

Weinberger, C., 1984. The Uses of Military Power. [online] Washington, D.C.: National Press Club. Available at: <http://www.airforcemag.com/ MagazineArchive/Documents/2004/January\%202004/0104keeperfull.pdf> [Accessed 02 April 2019] 


\section{Overcoming Conflicts}

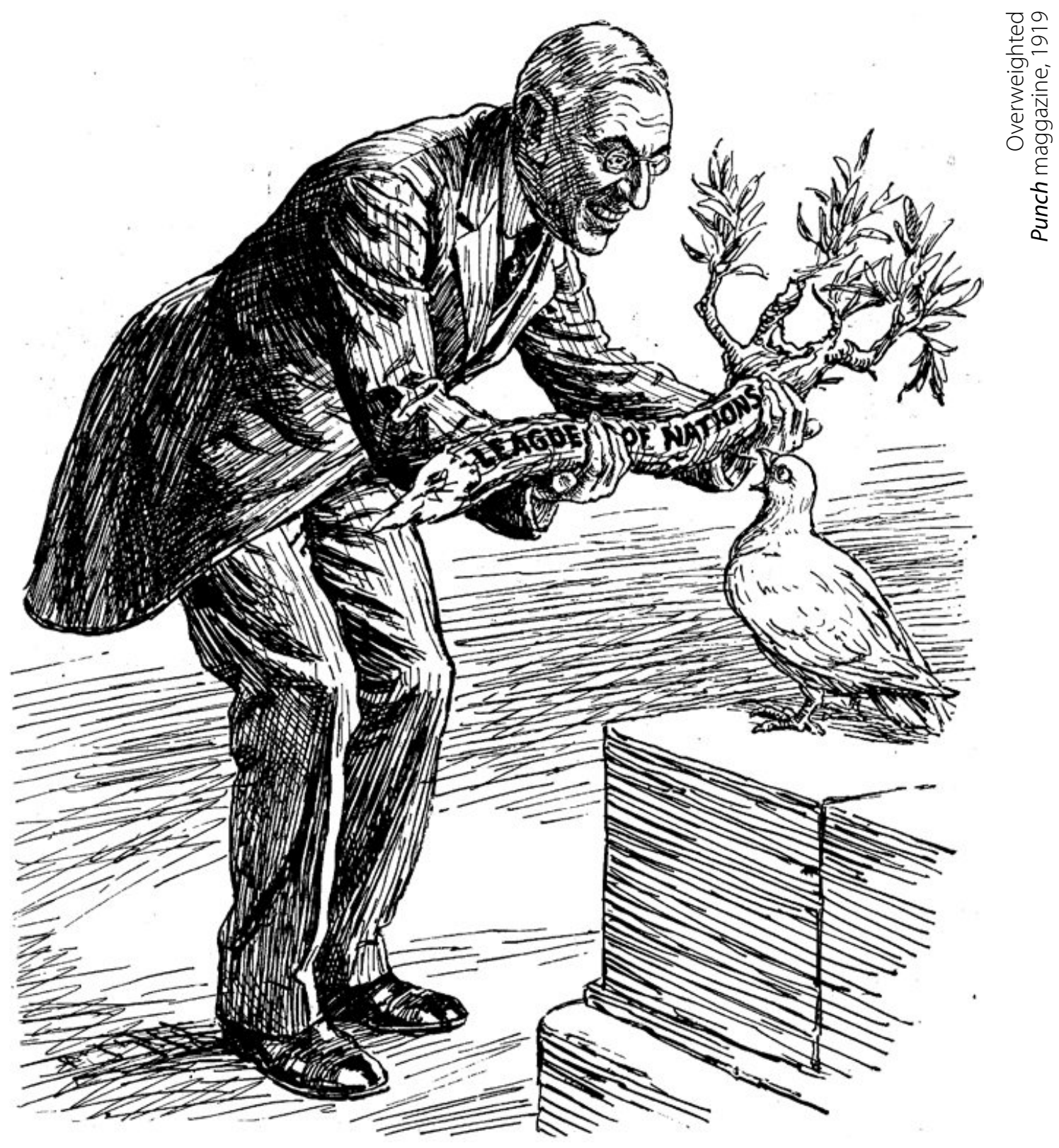

66 Alternative approaches to sovereignty, which imply the possibility of blending the legal systems of different states in the same territory, considerably expand opportunities for resolving territorial disputes. 99 


\title{
Where There's a Will, There's a Way
}

Ten Ways of Settling an Insoluble Territorial Dispute Igor Yu. Okunev

\begin{abstract}
Understanding 'sovereignty' as one and indivisible substance is very convenient for politicians and lawyers, but in the modern political reality it is hardly achievable. Alternative approaches to sovereignty, which imply the possibility of blending the legal systems of different states in the same territory, considerably expand opportunities for resolving territorial disputes. In this article vast historical material is used to illustrate the experience of implementing various models of territorial governance, such as an associated state, transboundary region, sovereign region, leased territory, free territory, no-man's territory, buffer zone, temporary administration, condominium, and commune. The described set of options may help break the deadlock in negotiations on almost any territorial dispute, provided the parties concerned have the political will to achieve a peaceful compromise.
\end{abstract}

Igor Yu. Okunev, Ph.D. (Political Science)

Department of Comparative Political Science, MGIMO University, Moscow, Russia

Associate Professor;

Center for European Studies, MGIMO University, Moscow, Russia

Senior Research Fellow

ORCID: 0000-0003-3292-9829

RSCI Author ID: 565228

SPIN RSCI: 7633-0618

Scopus Author ID: 56433053800

Researcher ID: E-4038-2012

Tel: +7945433 3495, ext. 1501

Address: 76, Vernadsky Prospect, Moscow 119454, Russia

DOI: 10.31278/1810-6374-2019-17-3-152-174 
Keywords: territorial disputes, associated state, transboundary region, sovereign region, leased territory, free territory, no-man's territory, buffer zone, condominium

Cerritorial disputes are extremely difficult to resolve. It has been the custom to perceive territory as the most valuable asset and

its significance has been sacralized over time. This is well seen in the latest Russia-Japan negotiations where both sides are clearly ready to meet each other halfway, but a mutually acceptable solution remains unachievable.

Ibelieve the reason is that the idea of the "indivisibility of sovereignty," i.e. that territory may belong entirely to one state only, dominates in world politics. In reality, this postulate is wrong. History has seen many examples of mixed sovereignty, which helps to realize the national interests of two peoples in the same territory. This article is an attempt to scrutinize the historical examples of such forms of territorial governance in the hope that such a study will help diplomats and politicians expand the range of options for resolving territorial disputes.

\section{MODERN THEORY OF SOVEREIGNTY}

The issue of sovereignty has always been central to political geography, because the state, the main object of study in this science, is traditionally understood through sovereignty (Okunev, 2019). The normative understanding of sovereignty as a concept linking power and society by legitimation (both internal and external) in a certain territory stems, in fact, from a political-geographical factor. The concept of sovereignty was formulated in the 16th century by French lawyer Jean Bodin and enshrined in the 1648 Peace of Westphalia, a series of peace treaties that put an end to the Thirty Years' War in Europe (Ilyin, 2008). The Westphalian system of international relations, which remains the pillar of the modern world order, rests upon the idea that sovereign states exercising full power in their territory are equal participants in international relations. 
There are two dominant approaches to sovereignty in modern political geography. According to one, attributive approach, sovereignty is realized through articulation and achievement of its interests by the state, and mainly through its foreign policy, in which case sovereignty is considered a stable characteristic of the state. The advocates of the other, subject-based, approach maintain that sovereignty is the result of political processes underway in a certain territory. In this case sovereignty has a dynamic (in terms of time and space) character. Thus, the first approach interprets sovereignty as an attribute of the state and its indispensable characteristic, while the second one, on the contrary, treats the state as the subject of sovereignty (Yack, 2001).

The first approach is based on the Westphalian understanding of sovereignty: the world consists of sovereign states that fully control their own territory. Despite the fact that this type of situation has never existed in reality, the advocates of this approach are adamant that full sovereignty is a necessary organizing principle of the state and a natural attribute of political power. In this case, states are understood as autonomous individuals, homogeneous points without spatial differentiation, whose behavior reflects certain homogenous internal interests and who act as subjects of international relations and fight with each other for survival, which brings about rigid dichotomies of "inside-outside" and "friend or foe" type (Sergunin, 2010).

The second, subject-based approach suggests that the state should be understood not as a source of power, but as a derivative of sovereignty, of the political processes taking place in the name of a given state in a certain territory, in which power and society are connected by internal and external legitimation and constitute a single identity. States become subjects of international relations, embedded in this system through their foreign policy (Okunev, 2011). Sovereignty ceases to be a specific construct embodied in different forms and different mechanisms, depending on the historical and geographical context. Therefore, the second approach allows us to see a new dimension of sovereignty as a discursive space-based phenomenon (Agnew, 2003).

The hypothesis of this paper is that the described subject-based understanding of sovereignty expands the range of possible tools in 
resolving a territorial dispute. We will list such options of flexible attitude to sovereignty in combination with examples from world history.

\section{Create a transborder region}

A transboundary region is an integration association of contiguous regions of countries created for the institutionalization of border cooperation (Fedorov, 2010). Geographically, a transboundary region is the minimum unit of integration. However, this does not mean the least possible degree of integration of these entities: although sometimes they are created as supporting zones for future interstate integration (Chinese transboundary trade zones on the border with Russia and Central Asian countries). More often than not they already represent a stage of deeper interstate integration, transferring it to the regional and local level (Euroregions in the EU) (Nikitina, 2010).

The creation of transboundary regions resolves a set of interdependent problems: it eliminates historical barriers, contributes to the socio-economic development of border areas located at their countries' periphery, overcomes the barrier functions of the state border, enhances security, and improves the country's image (Kuznetsov, 2012).

Attempts to institutionalize transboundary cooperation have repeatedly occurred since the 19th century (for example, the SpanishFrench commission for cooperation in the Pyrenees region), but they peaked in Europe after the war largely due to targeted policies by the European Union.

The following types of transboundary regions can be distinguished:

- transboundary working communities, which are a format of broad interregional cooperation that does not envisage creation of supranational governing agencies (the Association of the Alpine States, Barents Euro-Arctic Council, Mano River Union);

- transboundary movement zones, in which visas for shortterm trips are not needed for residents of neighboring regions (for example, in the Russian-Norwegian, Russian-Polish, and Russian-Lithuanian borderlands);

- transboundary trade zones that stimulate transboundary trade relations and trade between regions (especially popular 
in China, as they exist on the Russian-Chinese border in Blagoveshchensk-Heihe, Pogranichny-Suifenhe, ZabaikalskManchuria, and Zarubino-Hunchun);

- transboundary agglomerations, where cooperation proceeds within the framework of cities divided by borders (for example, the Eurodistricts of Strasbourg-Ortenau, Freiburg-Alsace, Saar-Moselle, and Lille-Kortrijk);

- Integrated transboundary regions characterized by a high share of cooperation and multifactored cooperation, on the one hand, and consistency and independence of the management structure, on the other (Euroregions of the German-Dutch EUREGIO, Lake Constance Conference) (Strezhneva, 2011).

The degree of institutionalization and activity of transboundary regions varies from continent to continent. Whereas in Europe it is almost impossible to find a region that does not participate in such structures, in other continents this form of integration still remains an exception (Pestov, 2015).

\section{Lease the territory}

A leased territory is a sovereign territory temporarily transferred to another state for possession or use (Chernyshev, 2010). There are two types of leased areas:

- Sovereign rented territories: sovereignty over these regions was temporarily transferred by the lessor country to the lessee country (British Hong Kong in China in 1898-1997).

- Non-sovereign leased territories (concessions): the lessor country retains sovereignty over the territory, while the lessee country receives only temporary rights for using and applying its legislation (Russia’s Baikonur in Kazakhstan in 1992-2050).

Leasing territories was extremely prevalent during the growing external influence in China in the second half of the 19th century. During that period, Hong Kong was leased to Britain, Macao to Portugal, Guangzhouwan to France, Jiaozhou to Germany, and Taiwan 
to Japan (Baker, 1995). In 1898, Russia obtained a 25-year lease of the Kwantung territory on the southwestern tip of the Liaodong Peninsula, which included the naval port of Port Arthur, the trade port of Dalniy (now Dalian), and the region's old Chinese capital of Jinzhou. After Russia's defeat in the Russian-Japanese War, the territories were ceded to Japan, only to be taken back by the Soviet Union after World War II. The final transfer of the jurisdiction over this territory to China took place in 1955. The last leased territories-Hong Kong and Macaoreturned to China in 1997 and 1999, respectively, with the status of special administrative regions.

Leased territories are also an important factor in Russian-Finnish relations. In the 1940s and 1950s, the Soviet Union rented from its northern neighbor the Hanko and Porkkala Udd peninsulas to deploy naval bases there (Filippini, 2016). In exchange, the section of the Saimaa Canal located in the Leningrad region was leased to Finland in 1962. This canal, connecting Lake Saimaa with the Baltic Sea in the area of the former Finnish city of Vyborg, is of strategic importance because it serves as a link between the country's internal economic regions and international shipping routes. In the post-Soviet period, the lease contract was extended until 2063. Finnish legislation, including navigation rules, is valid in the territory of the canal, while Russian customs restrictions are ineffective. At the same time, the canal cannot be used for the transportation of troops, armaments, or ammunition, and Russian ships are entitled to free passage through the Russian part of the canal (Okunev, 2014).

Rented by Russia from Kazakhstan since 1992, the city of Baikonur, along with the cosmodrome of the same name, is the largest leased territory in the world and has a unique political and legal status. While remaining a sovereign territory of Kazakhstan, it exists within the Russian legal space. Although it enjoys the status of a Russian city of federal significance (along with Moscow, St. Petersburg, and Sevastopol), Baikonur lacks the constitutional status of a territory of Russia. Its departments of legislative and executive power are not represented in Russia's Federation Council. The head of the city authorities is appointed by the presidents of the two countries and no 
representative agencies of local self-government exist. Russian courts, police stations, schools, hospitals, and post offices are located in the territory of Baikonur.

\section{Convert communities in the territory to free communes}

A number of territorial communities in the world drop out from a common political space. In doing so, they form their own utopian, self-sustaining settlements called communes. Their residents, without laying claim to state sovereignty, establish their own rules of living together.

A typical commune has the following characteristics:

- a common utopian idea (of a sociopolitical, religious, or ecological nature), often associated with the intention to achieve an ideal society;

- collective ownership prevails;

- the commune's socio-economic and ecological seclusion from the outside world.

Usually a commune is home to several dozen to several hundred people-mostly middle-aged and elderly-engaged in common pursuits and undertakings (most often in agriculture). Communes that independently provide education for the children are now very scarce, so a majority of young people leave the communes when they grow up. Contrary to common gossip, most communes are heterosexual and monogamous, although "free love" communities (for example, ZEGG in Germany or Krista in the U.S.), or communes professing total abstinence from sexual intimacy still exist. Politically most communes are governed by democratic procedures, although there are also anarchic, authoritarian, and even totalitarian varieties. The international public association called Fellowship for Intentional Community (FIC) provides interaction among communities around the world.

Apparently, the oldest communes in the world are settlements of the Hutterites (for example, the commune Bon Homme, which has existed since 1874). The trend to defend the principle of common property emerged as a branch of the Anabaptists in Germany. After a period of wandering around Eastern Europe, they migrated to North 
America. The Hutterites live by agriculture and petty handicraft, retain their native language called Hutterisch (which is close to German), are pacifists, do not serve in the army, and defend the right not to be photographed even for IDs, since this contradicts the first commandment. Religiously close to the communes of the Hutterites are the Bruderhof communities, scattered around the world from Britain to Paraguay. The Amish and the Mennonites (religiously close to the Hutterites, too), who reside in the U.S. and Canada and practice a traditional lifestyle (in particular, the former do not recognize modern technologies), are not typical communes, because they do not recognize common property.

Israel's agricultural kibbutzim are another example of old-type communes. The first of them, Degania, was founded in 1910. Today there are about 300 of them, accounting for about $2.5 \%$ of the country's population, which is the highest ratio of commune residents in the world. The largest number of communes is found in the United States-more than 2,000. Alongside the U.S. and Israel, communes are common in some countries of Western Europe and Latin America, Australia, New Zealand, and India. Some communes are so active in the political sphere that they even begin to be perceived as quasi-states (for example, Christiania in Denmark).

\section{Make the disputed territory a sovereign region}

Sovereign regions enjoy broader powers than all other types of territorial units of the state. Unlike other autonomies with separate powers, sovereign regions possess sovereignty and each of them is something like a state within a state. Their right to secession (unilateral pullout from the parent state) can be considered the greatest attribute of sovereignty. None of them has exercised this right yet, though. Such broad powers often cause a great deal of confusion and such entities are taken for states in their own right (for instance, the Monastic Republic of Mount Athos), non-self-governing territories (like the Åland Islands), or unrecognized states (like Azad Kashmir). It turns out that sovereign regions incorporate individual features of all these border terms. Let us consider these three examples in greater detail. 
The Autonomous Monastic State of the Holy Mountain (Athos) is a sovereign region of Greece. Its status is significantly different from those of other territorial units of Greece. In fact, the region has complete autonomy and even some elements of sovereignty. With its secluded location on the same-name peninsula in Halkidiki, Athos is the world's largest cluster of Orthodox monasteries. The special sacral significance of the peninsula for Christianity (considered to be the earthly Garden of the Virgin Mary) means that predetermined prayer is the only permitted occupation on Athos. Therefore, tourists, non-Orthodox, and women (and even domesticated animals and pets) are not allowed into the territory of the state, while everyone else needs a blessing from the local church. In order to get to Athos a visitor needs to get a Diamonitirion (analogue of a visa) in Thessaloniki or Ouranoupolis in neighboring Greece and use a boat. In fact, this state has no political or economic system, because life proceeds according to monastic rules, and the administrative center of Karyes is endowed with exclusively coordinating functions. Dating back to the 7th century AD, the traditions of autonomous existence on Mount Athos are very old and were not interrupted by either the Ottomans or the Nazis. The current position inside Greece is determined by the fact that historically Orthodox states (mainly, Russia) claimed joint control of the territory and even brought troops there in 1917. The pro-Greek status serves as a safeguard against external interference (Basbanes, 1999).

The Åland Islands (literally, the "perch country") in the Baltic Sea are part of Finland. The Åland Islands are independent from Finland in matters of education, health, culture, transport, ecology, and communication (Deryabin, 2009). The islanders have separate citizenship and do not serve in the Finnish army. The only official language is Swedish and all Finns are required to study Swedish at school. During the 1918 Civil War in Finland, almost all the inhabitants of the Åland Islands voted in a referendum for reunification with Sweden, but the latter wanted everything to be arranged in conformity with international law, only to find no allies who would agree to spoil relations with the newly-emerged state following the breakup of the 
Russian Empire. The Åland Islands held a referendum on joining the EU to gain a place outside the tax union (Stanvridge, 2003). For this reason, all Baltic ferries making a ten-minute stop on the islands can trade dutyfree, thus making the islands a territory with one of the highest living standards in the world. There are eight consulates per 30,000 people in the Alands. The region is a member of the Nordic Council. The Russian consulate in the Åland Islands (a former westernmost province of the Russian Empire) has served as a guarantee of the demilitarized status of the archipelago (since 1856) (Rotkirch, 1986).

Azad Kashmir emerged as a result of the Indo-Pakistani conflict over the territory of the northern principality of Jammu and Kashmir. Relying on the decision of the former leadership of a predominantly Muslim principality, India has laid claim to its entire territory, although Pakistan and China control some of its parts. Formally sovereign, Azad Kashmir was established in the western part of the former principality and is actually governed from Islamabad.

Sovereign regions are also common in the post-Soviet space. They are the legacy of the right of the Soviet republics to secede from the state. This provision contributed to the legal consolidation of this status by some autonomies of the newly independent states. Some of them were later abolished (as in Tatarstan and Chechnya in Russia), while others have been preserved de jure (as in Gagauzia in Moldova or Karakalpakstan in Uzbekistan).

\section{Make the disputed territory an associated state}

UN GA Resolution 1541 (XV) defines the forms of self-determination for non-self-governing territories: conversion to a sovereign state, merger with another state and, finally, free unification with an independent state. The third option is implemented in the form of an associated state. An association with another state should be a free and voluntary choice of the country's population, made through clear and democratic procedures. While transferring some of its sovereignty to the other state and agreeing to dependence in certain domestic or foreign policy matters, the associated state retains, firstly, the right to determine its internal system (with the necessary consultations with 
the partner state) and, secondly, the right to unilaterally withdraw from the association by means of democratic expression of the people's will.

The status of associated states was initially used as a transitional one on the path to decolonization. In 1967, the British West Indies (Antigua, Dominica, Grenada, Saint Kitts, Nevis, Anguilla, Saint Lucia, and Saint Vincent) concluded an association agreement with the UK. After a few years, all of them, except Anguilla, became independent states. Anguilla, on the other hand, is an example of involution: it abdicated the status of an associated state within Saint Kitts and Nevis to return to the position of a dependent territory of Great Britain.

However, the status of an associated state can be quite stable, which is clearly seen in the associated states of the U.S. (the Marshall Islands, Micronesia, and Palau) and New Zealand (the Cook Islands and Niue) still existing on the modern political map.

The Cook Islands and Niue have had the status of associated states of New Zealand since 1965 and 1974 respectively. This status allows these territories, on the one hand, to receive financial support from Wellington and delegate to it foreign and domestic policy matters that are not essential for the islands, and, on the other hand, to enforce the political interests where it is crucial. Despite the fact that neither territory is a member of the UN, this does not prevent them from establishing diplomatic relations with sovereign states, including the United States, the European Union, and China, open embassies and join international organizations without upsetting friendly relations with the parent country.

Niue, perhaps, has the world's highest ratio of diplomatic personnel per the country's total population. With a population of just over one and a half thousand people the island has three embassies abroad, diplomatic relations with a dozen states, and is affiliated with a couple of dozen international organizations.

The Free Association Agreement has secured the status of the U.S.-associated states for the Marshall Islands and Micronesia since 1986 and for Palau since 1994. All three oceanic states had been part of the U.S.-governed Trust Territory of the Pacific Islands. After the transitional period they decided to become associated states of the 
former parent country. The countries have internal self-government, an opportunity to conduct their own foreign policy, and even hold seats in the UN, but within the association's framework they agreed to host military bases in their territory and delegate to the U.S. part of their sovereignty related to defense issues. In exchange they are entitled to financial support from the U.S. budget. If one traces the history of voting at the UN General Assembly, it turns out that these countries almost always agreed with their patron.

In Puerto Rico, yet another dependent territory of the United States, there is a movement for self-determination in the form of an associated state with the U.S. (known as sovereigntism) (Talbot, 1993), but recently it has ceded much of its influence to the movement for complete merger with the United States as the fifty-first state (Martinez, 1997). The Puerto Ricans have held referendums several times to confirm this choice, but the U.S. Congress has so far resisted such a decision, because it will entail significant financial costs and change the balance of power between the Republican and Democratic forces in federal elections in favor of the latter (Diaz, 1995).

\section{Create a buffer zone}

A buffer zone is a territory which separates conflicting parties and which remains under international administration. A buffer zone is a narrow strip of land, from several meters to several kilometers wide, that international institutions have created to control the line of demarcation between the conflicting parties for the period of the peace process. The population is usually evacuated from the zone and a demilitarized regime is established.

Buffer zones gained recognition after their establishment during civil conflicts in the Cold War era. Demilitarized zones several kilometers wide were created in 1953 along the 38th parallel between North Korea and South Korea, and in 1954 along the 17th parallel between North Vietnam and South Vietnam. Both zones were governed without international participation and proved to be extremely unstable. The Vietnamese zone was constantly a theater of military operations and was eventually abolished in 1976 after the unification of Vietnam. The 
Korean demilitarized zone still exists today despite a series of border clashes, although its degree of demilitarization is questionable.

Later, buffer zones were created under the auspices of UN peacekeeping missions:

- The Green Line-the UN buffer zone in Cyprus (established in 1964 between Cyprus and partially recognized Northern Cyprus and controlled by the UN Peacekeeping Force in Cyprus (UNFICYP)) (Broome, 2004, Webster, 2006);

- The Purple Line-the UN buffer zone in the Golan Heights (established in 1974 between Israel and Syria and controlled by the UN Disengagement Observer Force (UNDOF));

- UN buffer zone in southern Lebanon (established in 1978 between Israel and Lebanon and controlled by the UN Interim Force in Lebanon (UNIFIL));

- UN buffer zone on the Iraq-Kuwait border (established in 1991, until 2003 was controlled by the UN Iraq-Kuwait Observation Mission (UNIKOM)).

There are some buffer zones managed by other international organizations. In 1982, without receiving a mandate from the United Nations, the United States, Israel, and Egypt created their own mission of international forces and observers to administer the multilevel buffer zone on the Sinai Peninsula.

Since 1999, there has been a zone on the border of Serbia and Kosovo under the leadership of the NATO Kosovo Force (KFOR). In 2013, it was decided to create a ten-kilometer buffer zone controlled by the African Union on the border of Sudan and South Sudan.

\section{Transfer the territory in interim trust of an external administration}

A temporary administration is established by international organizations (usually the UN) in sovereign territories for peacemaking and state-building purposes (Korhonen, 2001). For a certain period, part of authority, including legislative, executive, and judicial powers, is transferred to a special international mission formed for this 
purpose. Usually, an interim administration is established during a post-conflict period in order to set up new institutions of state power and hold democratic elections.

A number of $\mathrm{UN}$ missions were created with the aim of establishing temporary administration for various regions of the world:

- United Nations Temporary Authority in West New Guinea (West Irian) in 1962-63, created for the peaceful transfer of territory from the Netherlands to Indonesia (UN Temporary Executive Authority (UNTEA));

- United Nations Transitional Authority in Cambodia in 199293, established to end the Vietnamese occupation of Cambodia, adopt a constitution, and hold elections to executive bodies of power ((UNTAC operation by the United Nations Transitional Authority in Cambodia);

- United Nations Transitional Administration in Eastern Slavonia, Baranja and Western Sirmium (UNTAES) in 199698, created to reintegrate these regions into Croatia after the elimination of the self-proclaimed Republic of Serbian Krajina;

- United Nations Transitional Administration in East Timor (UNTAET) in 1999-2002, created for the period of the formation of government agencies after the referendum on the independence of East Timor from Indonesia.

Today, Kosovo and the Brčko District (Bosnia and Herzegovina) are under partial international control.

The United Nations Interim Administration Mission in Kosovo (UNMIK) was established in 1999 to form a government in the context of the region's wide autonomy within Serbia. After the declaration of Kosovo's independence, the mission's tasks were significantly revised. In 2012, the external control functions were terminated, but the mission continues to work, focusing on security, stability, and human rights issues. Some of the mission's tasks were redistributed among other organizations-NATO (security), the OSCE (democratization and institution building), and the EU (law, order, reconstruction, and economic development). 
The United Nations Mission in Bosnia-Herzegovina (UNMIBH) operated in the country from 1995 to 2002. Its task was to coordinate the implementation of the Dayton Peace Agreement after the Bosnian War, in particular, the transfer of power to the Peace Implementation Council. The Council decided to introduce the High Representative's provisional administration for the Brčko District, which holds a strategic position to ensure communication between the fragmented parts of the Republika Srpska and the Muslim-Croat Federation within one country.

\section{Make the disputed territory free}

Free territories drop out of the established system of international relations where the status of spaces is defined through the concept of sovereignty. These are separate political entities (a sovereign state or part of it) under international administration. Free territories are not fully sovereign, since in key matters, primarily related to security and foreign policy, they are governed by the international community, but at the same time they are not international, since they do not belong to the entire world community and retain their independence in matters of self-government. Free territories should also be distinguished from the types of dependent territories under international administration-mandated and trust territories. Free territories were initially sovereign, while mandated and trust territories were created with the aim of giving them sovereignty or putting them under the control of another sovereign state.

As a rule, free territories are created to freeze territorial claims and ease tensions in interstate relations. For example, the status of a UNgoverned free territory was proposed for Jerusalem and Bethlehem according to the 1947 UN Partition Plan for Palestine, not destined to be realized due to the start of the Arab-Israeli war. Most often this tool was used in the first half of the 20th century.

The Tangier International Zone (1912-1956) was established on the southern coast of the Strait of Gibraltar. The international status of the city was established by the League of Nations: nominally it remained under the control of Morocco, but the actual control was exercised by France, Spain, and the United Kingdom. Tangier was administered by 
the legislative assembly consisting of four delegates from France, four from Spain, three from Britain, two from Italy, one from the U.S., one from Belgium, one from Denmark, and one from Portugal, appointed by the consuls of their respective countries, and nine subjects of the Sultan. The zone was eliminated after the decolonization of Morocco.

The free city of Fiume (1920-1924) received its status after the signing of the Treaty of Rapallo between Italy and Yugoslavia. An important port in the Adriatic Sea, Fiume caused a territorial dispute between the two countries after the collapse of the Austro-Hungarian Empire. Formally an independent city-state, Fiume was recognized by the United States, Great Britain, and France, but starting in 1922, it was actually ruled by Italy and officially joined Italy two years later. After World War II, the territory became part of Yugoslavia, and today the city called Rijeka is part of Croatia (Kiselnikov, 2013).

The free city of Danzig (1920-1939) on the Baltic Sea was founded after World War I under the Treaty of Versailles. It was placed under the control of the League of Nations and had to enter into a customs union with Poland, which represented it in foreign policy relations. In this self-governing city, pro-Nazi sentiment was very strong, and it was Berlin's attack on Danzig on September 1, 1939 that launched World War II. After the war the city became part of Poland and is now Gdansk (Zubachevsky, 2015).

The territory of the Saar Basin (1920-1935) and the Saar Protectorate (1947-1956) emerged as a result of the Franco-German confrontation over the possession of the Saar coal basin during the two world wars. After World War I, the League of Nations governed Saar for fifteen years. The district was ruled by a commission of representatives from the Anglo-French force of occupation, but in the 1935 referendum it came out for reunification with Nazi Germany. History repeated itself after World War II. Saar became part of the French zone of occupation. France wanted to create a buffer state there under the joint control of the West European Union, but again its residents demanded reunification with Germany. However, it was precisely in Saar that the coal and steel industries of two eternal rivals were merged for the first time, heralding the first step towards the creation of the European Union (Lloyd, 1995). 
The Memel Territory (1920-1923) in East Prussia was also separated from Germany in the Treaty of Versailles and placed under the League of Nations mandate. In fact, it was under French administration. However, plans for creating a free city collapsed when the city's Lithuanian majority rose in revolt. This city on the Baltic Sea went to Lithuania and since then has been known as Klaipeda.

The Free Territory of Trieste (1947-1954) in the northern Adriatic was placed under direct UN responsibility in the aftermath of World War II with the aim to resolve the territorial conflict with Yugoslavia over Istria (Kunz, 1948). Soon the territory was divided between the two countries. The city itself remained part of Italy, but Yugoslavia was promised free access to the port. After the collapse of Yugoslavia, the Slovenian and Croatian parts of Istria saw an upsurge in irredentist sentiment.

On the modern political map of the world, perhaps, the only example of a free territory is Spitsbergen. The Spitsbergen Archipelago, together with Bear Island in the Arctic Ocean, had remained no-man's territory until the 20th century. Economic activity there was limited, but the primary players were Russia and Sweden. The Spitsbergen Treaty was concluded in 1920. The territory was taken over by Norway following its breakaway from Sweden, but an international legal regime was established, with all the signatories enjoying equal rights to use its benefits. The archipelago's demilitarized status was proclaimed and all parties to the treaty gained equal rights to economic activity, navigation, and scientific research in the archipelago. Currently only Norway and Russia are economically active on the island. In the only remaining Russian community of Barentsburg, the Russian stateowned coal company Arktikugol still operates today. It does not pay Norwegian taxes and uses only the Russian language and the Russian national currency. Russians can visit Spitsbergen without a visa, provided that they arrive there by direct charter flight from the territory of Russia. The strategic significance of Spitsbergen for Russia stems from the importance of monitoring the demilitarized status of the archipelago that is part of a NATO country and located in an area adjacent to the Russian Arctic sector (Stagestad, 1975). 


\section{Make the disputed territory no man's land}

No man's land (terra nullius) is a space that is neither under someone's sovereignty, nor an international territory (Buchkovsky, 2017). Initially, this term was applied to unexplored territories with a not yet determined legal status. In the 20th century there are no territories of this type left. Therefore, the term is used only in the narrow sense to designate territories over which all other states have refused to exercise their sovereignty. A territory is relinquished for one of three reasons: (1) under pressure from the international community, for instance, following a military defeat; (2) with the aim of arranging for a swap of territories, or (3) because it is impossible to govern the territory effectively. In all cases, after abdication by one country the territory in question has not been taken over by any other recognized state, nor has the international community recognized this territory as common.

For example, the colonial possessions of Japan, which it ceded under the San Francisco Peace Treaty, could have become no-man's territory.

Tokyo surrendered some territories without their transfer to a specific state (from the Kuril Islands and the Japanese sector of Antarctica (Marie Byrd Land and Ellsworth Land). Nevertheless, the status of these territories was determined by other countries: the Kurils are part of Russia, and the status of an international territory is recognized for Antarctica. The former Japanese sector of Antarctica is still the only unclaimed piece of land by any power in the world, which makes it similar to no-man's land.

The appearance of no-man's territories, called neutral zones, was characteristic of defining the border between the British colonies in Mesopotamia and Saudi Arabia (then the Sultanate of Nejd). The definition of such zones under the 1922 border treaty was associated with the inability to effectively manage the border in the desert, which nomadic tribes regularly crossed either way in search of rare oases. The neutral zone on the Saudi-Kuwaiti border existed until 1970, and on the Saudi-Iraqi border, until 1991.

Rare examples of no-man's territories on the present-day political map of the world are Gornja Siga on the Serbo-Croatian border and Bir- 
Tawil on the Sudanese-Egyptian border. Both appeared as a result of unsuccessful attempts to resolve territorial disputes between the countries.

Since the breakup of Yugoslavia and the war for Serbian Krajina, Serbia and Croatia have had mutual territorial claims to some of the disputed border territories, which, however, do not concern the uninhabited wooded territory Gornja Siga, seven square kilometers in size on the bank of the Danube. Neither country lays claim to it so as to avoid the risk of losing other more important disputed territories.

The Bir Tawil sector appeared on the map when the British Empire in 1902 redrew the border between two dependent territories: Egypt and Sudan. The Hala'ib Triangle, with its access to the Red Sea, was transferred to Sudan in exchange for the uninhabited sector of Bir Tawil in the desert. Today, Egypt does not recognize the 1902 treaty and, accordingly, its own sovereignty over Bir Tawil, while maintaining control of Hala'ib. On the contrary, Sudan recognizes the border established by the British, thus renouncing any claim to Bir Tawil. As a result, both states have given up their sovereign rights to the given territory where no legislation is in force.

\section{Establish a joint governance regime}

As a rule, a territory falls under the sovereignty of one state. However, historically there have been examples of joint administration of territories by two, three, or even four states. Condominiums are a very effective way of resolving territorial conflicts.

Condominiums should not be confused with international territories (for example, Antarctica), which belong to all countries of the world, since in condominiums there is always a clearly defined list of governing countries. In some cases, condominiums are very close to free territories and the rules of administering land-locked seas, international rivers, and lakes (the Caspian Sea, Lake Constance, and such rivers as the Danube, the Rhine, and the Moselle). However, in the described cases the point at issue is not that contracting states agree to control only certain types of activity (peaceful transit, freedom of economic activity), whereas in condominiums, the administering states spread their sovereignty over all aspects of the territory's functioning. Condominiums also differ from 
temporary administrations (the Brčko district in Bosnia-Herzegovina), since their creation has no chronological restrictions.

Condominiums have existed in three forms:

- Feudal condominiums-de facto independent microstates cogoverned by the heads of the neighboring major powers that emerged in the era of feudal fragmentation (Spanish-Portuguese Couto Misto in 1139-1868, Maastricht in 1204-1794 under the rule of Bishop of Liege and Duke of Brabant;

- Border condominiums-communities under common administration, established for the settlement of territorial disputes (Russian-Danish Fælles Distrikt (common district) on the Kola Peninsula in 1684-1826, the Belgian-German Moresnet in 1816-1919);

- Colonial condominiums-joint dependent territories that could not be governed alone (Russian-Japanese Sakhalin in 1855-1875, Anglo-Egyptian Sudan in 1899-1956 (Willis, 2003), Anglo-French New Hebrides (present Vanuatu) in 1906-1980).

Co-government by three states is extremely rare. The very short list of tridominiums includes the Britain-Australia-New Zealand-administered Nauru in 1923-1968, the British-U.S.-Germany-ruled Samoa in 18891899, and the Prussia-Austria-Russia-governed Free City of Krakow in 1815-1846. At least one example of a quatrodominum is known-the Principality of Samos in the Aegean Sea in 1834-1912. Administered by Turkey, Russia, Britain, and France, it eventually became part of Greece.

The only existing example of a feudal condominium is Andorra, established in 1278. Its heads of state are the President of France (after the French Revolution the post was passed over to him from the Counts de Foix) and the Archbishop of Urgell, from Spain. In fact, the country is a parliamentary republic, but formally all documents are still approved in Paris and Urgell. In 1993, the co-rulers expanded the sovereignty of Andorra: it was granted the right to independently engage in foreign policy (after which it was admitted to UN membership) and, for example, was given the choice not to arrange an annual feast with obligatory local cheeses, roosters, and partridges, 
clearly stipulated by the original contract. The only attempt in the centuries-old history to achieve full independence was undertaken by the Andorrans in 1934 under the leadership of Russian émigré and adventurer B. M. Skosyrev, who declared himself King Boris I of Andorra. Several days later, after issuing a decree to open a casino in the capital, he was arrested by the Spanish gendarmerie.

Condominiums do not have to be a form of governing dependent territories. Today there are examples of co-administration of parts of the country's incorporated territory that are very similar to the transboundary type of historical condominiums. The oldest existing condominium in the world - the tiny Pheasant Island-emerged after the signing of the Treaty of the Pyrenees between Spain and France in 1659. This condominium is a unique example not only of joint administration, but also of alternate administration by the two countries: for six months the island is run by the Spanish municipality of Irun, and for another six months by the French municipality of Hendaye. During the war, the condominium was declared a neutral territory, where monarchs met and prisoners were exchanged. Another example is the village of Hadt, located between Oman and Masfout in the Emirate of Ajman (UAE), which is under the joint control of the Sultan and the Emir.

The presented list of solutions and examples is not exhaustive, perhaps, but it is sufficient to understand that international experience has accumulated enough tools to resolve any territorial dispute. Success depends only on the competence of the negotiators and the political will of the leadership.

\section{References}

Agnew, J.A., 2003. Geopolitics: Re-Visioning World Politics. London, New York: Routledge.

Baker, H.D.R., 1995. Hong Kong: A View from Both Sides. Asian Affairs, 26(1), pp. 10-19.

Basbanes, N., 1999. Mount Athos Where "Every Stine Breaths Prayers". Smithsonian, 30(5), pp. 90-99. 
Broome, B.J., 2004. Reaching across the Dividing Line: Building a Collective Vision for Peace in Cypris. Journal of Peace Research, 41(2), pp. 191-209.

Buchkovsky, A., 2017. Questions “Terra Nullius" in International Legal Aspects. International scientific journal "Internauka", 2(18(40)), pp. 82-84.

Chernyshev, D.N., 2010. International Lease of State Territory with the Goal to Facilitate Transportation. Concise Compilation of Articles from Representative Power-21st Century, 5-8, p. 9a.

Deryabin, Yu. S., 2009. Alanskiye ostrova: osobaya avtonomia potomkov vikingov [Åland Islands: A Special Autonomy of Viking Descendants]. Sovremennaya Evropa [Modern Europe], 1(37), pp. 124-131.

Diaz, J.O., 1995. Puerto Rico, the United States, and the 1993 Referendum on Political Status. Latin American Research Review, 30(1), pp. 203-211.

Fedorov, G. and Korneevets, V. (2010). Transborder Regionalization in the Conditions of Globalization. Baltic Region, 4(6), pp. 92-102.

Filippini, C., 2016. Constitutions and Territorial Claims: Lessons from the Former Soviet Space. Studies in Territorial and Cultural Diversity Governance, 6, pp. 174-193.

Ilyin, M.V. and Kudryashova, I.V. (eds.), 2008. Suverenitet. Transformatsia ponyatii $i$ praktik [Sovereignty. Transformation of Notions and Practices]. Moscow: MGIMO University Press

Kiselnikova, N.V., 2013. Istoki "problemy Fiume" v mezhdunarodnyh otnosheniyah posle zavershenia Pervoi mirovoi voiny [The origin of "the Fiume problem" in international affairs after the end of WWI]. Nauchny dialog, 1(13), pp. 55-65.

Korhonen, O., 2001. International Governance in Post-Conflict Situations. Leiden Journal of International Law, 14(3), pp. 495-529.

Kunz, J.L., 1948. The Free Territory of Trieste. Political Research Quarterly, 1(2), pp. 99-112.

Kuznetsov, A.V., 2012. Transborder Corporate Integration in the Baltic Sea Region. Baltic Region, 1(11), pp. 11-18.

Lloyd, L., 1995. The League of Nations and the Settlement of Disputes. World Affairs, 157(4), pp. 160-174.

Martinez, R.B., 1997. Puerto Rico's Decolonization. Foreign Affairs, 76(6), pp. 100-114.

Nikitina, Yu. A., 2010. Ot integratsii $\mathrm{k}$ regionalizmu: evolyutsia teorij reginal'nogo mezhgosudarstvennogo sotrudnichestva [From Integration to 
Regionalism: Evolution of the Theories of Regional Interstate Cooperation]. Vestnik MGIMO, 6(15), pp. 134-140.

Okunev, I.Yu., 2011). Politiko-geograficheskiye aspekty gosudarstvennosti (analiz opyta mikrogosudarstv [Political-Geographical Aspects of Statehood (An Analysis of the Experience of Micro-States)]. Politicheskaya nayka, 4, pp. 162-174.

Okunev, I. and Domanov, A., 2014. Space Imagination and Mixed Identity in Russian Towns Bordering on Finland. Human Geographies, 8(2), pp. 101-110.

Pestsov, S.K., 2015. Border and Transborder Regions. In: Sevastianov, S.V, Laine, J.P. and Kireev, A.A. (eds.) Introduction to Border Studies. Vladivostok: Dalnauka, pp. 139-154.

Rotkirch, H., 1986. The Demilitarization and Neutralization of the Aland Islands: A Regime "In European Interests" Withstanding Changing Circumstances. Journal of Peace Research, 23(4), pp. 357-376.

Sergunin, A.A., 2010. Suverenitet: evoltyutsia kontsepta [Sovereignty: Evolution of the Concept]. Politeks, 6(4), pp. 5-21.

Stagestad, G., 1975. The frozen frontier: models for international cooperation. Cooperation and Conflict, 10(3), pp. 167-187.

Stanvridge, K., 2003. Master Frames, Political Opportunities, and SelfDetermination: The Åland Islands in the Post-WWI Period. The Sociological Quarterly, 43(4), pp. 527-552.

Strezhneva, M.V., (ed.), 2011. Transnatsional'nye politicheskie prostranstva: yavlenie i praktika [Transnational Political Spaces: Phenomenon and Practice]. Moscow: Ves' Mir.

Talbot, J.F., 1993. Puerto Rico Says 'Yes' to Commonwealth Status. America, 169(20), p. 4.

Webster, C. and Timothy, D.J., 2006. Travelling to the 'Other Side': The Occupied Zone and Greek Cypriot Views of Crossing the Green Line. Tourism Geographies, 8(2), pp. 162-181.

Willis, J., 2003. Violence, Authority, and the State in the Nuba Mountains of Condominium Sudan. The Historical Journal, 46(1), pp. 89-114.

Yack, B., 2001. Popular Sovereignty and Nationalism. Political Theory, 29(4), pp. 517-536.

Zubachevsky, V.A., 2015. Problema Dantsiga i pol'skogo koridora v germanepol'skih otnosheniyah v 1929-1933 godah [The Problem of Danzig and of the Polish Corridor in German-Polish Relations in 1929-1933]. Voyennoistorichesky zhurnal, 7, pp. 14-19. 


\title{
Per Aspera ad Pax
}

\author{
The Syrian Crisis: A Thorny Path from War to Peace
}

\section{Alexander G. Aksenyonok}

The second decade of the 21 st century began with a string of explosive protests in the Middle East and North Africa. The region has become a source of violence and terrorism, dramatic national upheavals, humanitarian catastrophes, and waves of migration. Most countries (Egypt, Tunisia, Morocco, Jordan, Saudi Arabia) have launched the needed socioeconomic reforms, albeit belatedly, but outcomes are difficult to predict. A way out of the profound systemic crisis is yet to be found.

\section{WHAT MAKES THIS CONFLICT SO DISTINCT}

The Syrian crisis, while reflecting the general grievous state of the Greater Middle East, is still a special case resulting from profound changes in the alignment of forces at the global and regional level. The majority of the 21st century's geopolitical, ideological, social, and ethno-religious cataclysms have been concentrated in precisely this region.

The conflict in Syria unfolded in a historical period when Russia-U.S. relations were slowly, but surely, deteriorating from the erstwhile partnership of the late 1990s and early 2000s to a Cold War confrontational model. The generally accepted norms of international law were unilaterally revised, while a collective crisis settlement mechanism advocated by Russia never materialized. As the President

Alexander G. Aksenyonok, Ambassador Extraordinary and Plenipotentiary, Vice-President of the Russian International Affairs Council.

This article is an abridged version of the paper written for the International Valdai Discussion Club. The original version is available at: http://valdaiclub.com/a/valdai-papers/the-syriancrisis-a-thorny-path-from-war-to-peace/ 
of Russia suggested at the Valdai Forum in 2014, this mechanism might include a "coherent system of reciprocal commitments and agreements" and "clear-cut conditions under which interference is necessary and legitimate" (Valdai, 2014).

The protracted Syrian crisis has presented the international community with a major dilemma: Will it be able to extinguish the tinderbox of conflicts or will it allow regional centers of power to engage in military rivalries designed to promote their geopolitical interests and indulge their outsize ambitions. In this sense, the outcome of the civil war in Syria will have implications that go far beyond the regional framework. When the nationalist wave was at its crest, Egypt was called the "head of Arabism and Syria, its "heart'." The concept of Arabism no longer has the same ring to it: Egypt is no longer the leader, new centers of financial and political influence have emerged in the Gulf area, and non-Arab regional players such as Turkey, Iran, and Israel are now ascendant. The altered alignment of forces at the regional level has turned Syria into an arena where Sunni Saudi Arabia and Shiite Iran, the two religious centers and leaders of the two main Islamic denominations, are locked in an indirect battle (The Iranian-Saudi Hegemonic Rivalry, 2017). A full-scale civil war in the centre of the Arab world with its closely intertwined interests-both clashing and to some extent overlapping-has complicated the search for mutually acceptable agreements and made coalition ties fluid and ambiguous.

In Syria, the military contingents and bases of six foreign statesRussia, Iran, Turkey, the U.S., France, and the UK-are deployed in close proximity. But it is only Russia and Iran that have international legal grounds (an invitation from the Syrian government) for being there. This incredibly compact foreign military presence, including non-government paramilitary units (proxies), not only involves unpredictable risks but also equips each of the players on the ground with military and political tools that make it possible to disrupt any final outcome it finds unacceptable. The Syrian crisis is also a mirror reflecting the growing influence of regional actors, each playing a game of its own within the wider context, whose local agendas increasingly often clash with the global interests of the major powers.

There is yet another reason why the Syrian crisis is so idiosyncratic and difficult to settle. The multilateral talks on the future system 
of government in Syria have been held against the background of continued military operations punctured by short-lived ceasefire. In the international context, institutional reforms normally follow the military phase. In Syria, internationally mediated agreements on reforms between the direct participants in the conflict should in effect become the condition for ending the hostilities and focusing joint efforts on combating the persisting terrorist threat.

\section{THE CURRENT STATE OF PLAY ON THE MILITARY MAP}

The eight-year Syrian crisis can be roughly divided into two stages: 1) before Russia's decisive military intervention in September 2015, and 2) after the Russian Aerospace Forces launched operations in Syria, enabling Damascus to restore control over the majority of Syrian territory and to destroy the military infrastructure of ISIS lbanned in Russial and other terrorist groups.

The sporadic anti-government protests in late February and early March 2011 were initially peaceful in nature. The protests reached critical mass and began sweeping the country after the Syrian leadership abruptly had given in to the omnipotent securicrats who urged the president to stop making concessions and put down the uprising by force. In April and May, heavy weapons were used against peaceful protesters. Legislative measures to partially liberalize the political regime, calls to start a national dialogue, and even the approval of a new constitution in February 2012 were already unable to diffuse the tensions.

The Syrian opposition, as represented by political emigres and underground civil society organizations with motley ideological beliefs (ranging from liberals to Trotskyites to radical Islamists), was not in itself a threat to the regime, which relied on a well-oiled mechanism of harsh authoritarian power. The rapid (in fact, instantaneous) transition to the military phase was caused by the overwhelming synergy between the explosion of spontaneous protests aided by the wide use of modern communications technologies, the authorities' disproportionate military response, and desertions from the army in combination with the mass infiltration of militants and arms across the borders from neighboring countries, which was directly supported by Turkey with financial backing from Arab Gulf monarchies, primarily Saudi Arabia and Qatar. Moreover, leaders in Syria's regional environs 
had "old scores" to settle with al-Assad: relations with the Syrian president in the run-up to the crisis varied from close cooperation to mutual recrimination. Religious factors were initially of minor importance, but as hostilities expanded and new players got involved, all sides began using religion as a means of mobilization.

The U.S. and leading EU countries immediately declared the alAssad regime illegitimate, recognized the opposition's political wing as the legitimate representative of the Syrian people, and pressured Damascus via the UN and other international organizations. The League of Arab States (LAS) took the unprecedented step of suspending Syria's membership. At that moment, regime change along the lines of Libya was a unifying principle for the anti-Assad coalition that emerged in the region. But as time went on, the clash of interests between the U.S. and its regional partners as well as among the major regional players (Turkey, Saudi Arabia, the UAE, and Qatar) reconfigured coalition ties and opened up new dimensions in the Syrian crisis.

However, the initial knee-jerk reaction was a major political blunder, as leading Western experts now admit. The United States failed to establish a firm base of military-political support in the Arab armed opposition. Nor did it manage to differentiate "moderate Islamists" from the rapidly proliferating terrorist organizations. But the insistent demands that al-Assad must go only fed the opposition's illusions that they could win a military victory and fueled the competition for political influence and control over arms flows and outside funding within their ranks. America's unconditional support for the opposition movement, where jihadists with links to ISIS and Al-Qaeda (banned in Russia) were rapidly gaining strength, predetermined the weakness of the U.S. diplomatic efforts and constrained the room for manoeuvre. This made Washington hostage to émigré politicians with their exorbitant demands and to their regional sponsors. It reached the point where U.S. policy was all too clearly playing into the hands of terrorists. This became particularly clear in the summer of 2014, when ISIS achieved spectacular military successes in Iraq and Syria, putting the Barack Obama administration in an even more awkward position.

Between 2012 and 2015, Damascus was burning through internal resources to neutralize military pressure at home. The armed 
opposition was expanding its zones of territorial control not only in northern and eastern Syria, where radical Islamists spilled over from Iraq, but also in the country's densely populated central areas. The Syrian army was not ready for urban warfare and gradually found itself on the defensive, focusing on guarding distant approaches to the capital, strategic centers, and transport infrastructure.

Lebanon-based Hezbollah joined the hostilities in 2012 while Iran was expanding direct military aid to Syria, including the enlistment of Shiite militias from Iraq, Afghanistan, and Pakistan. This made it possible to halt enemy advances towards vital centers for some time but also aggravated relations between different ethnic and religious communities, making the conflict particularly fierce on both sides. Having established close relations with Syria back in the mid-1980s, Iran managed to gain a firm foothold in Iraq and Lebanon during the years of regional upheaval and create extensive military infrastructure under its control. The Iranians regard Syrian territory as a key component of their national security strategy, which is focused on pushing back against Saudi Arabia and its claims to leadership in the Islamic world. Since the Donald Trump administration unilaterally withdrew from the Joint Comprehensive Plan of Action (JCPOA) and ratcheted up economic and political pressure against Tehran, Iran's regional strategy has been put to the test like never before. Signs of internal disaffection are surfacing more and more often in response to the dramatic financial constraints, growing economic hardship, and loss of life in the Syrian war (Iranians Respond, 2018). Questions are being asked about the limits of Iran's regional security and Syria's place therein as a crucial component of its broader strategy in relations with the U.S. and Saudi Arabia.

Turkey, which opted for rapid regime change in Damascus and support for Islamist organizations with ideological proximity to Recep Erdogan's ruling party, has modified its position substantially in the course of the conflict. This change of emphasis in regional policy was brought about by complications in the transition from a parliamentary republic to a strong presidential regime as well as by disappointment with U.S. and EU policy in Syria, on the one hand, and an understanding of the advantages of working with Russia on Syria as part of a broader bilateral cooperation framework, on the other. 
The changing regional picture was largely the result of the Kurdish factor, which always played and continues to play a significant role in the domestic politics of the countries forming the so-called Kurdish Triangle (Syria, Turkey, and Iraq). Soon after the start of hostilities, the Syrian government decided to phase out its military presence in north-eastern areas, where the Kurdish majority immediately established control. Erdogan's war on two fronts-one with the alAssad regime and the other with the armed Kurdish groups-failed to yield success and even led to a spate of ISIS terrorist attacks inside Turkey itself. Frictions intensified with the Americans, who had thrown in their lot with the Kurds after the latter had proved highly effective at waging anti-terrorist operations against ISIS. This created a situation where the Syrian Kurds, who got a unique opportunity to merge their enclaves in Afrin and Kobani, thought that this historic juncture was favorable for organizing an autonomous area on the northern border with Turkey (a Western Kurdistan of sorts) with a claim to independence. After Turkey broke off a ceasefire agreement with the Kurdistan Workers' Party (PKK) and banned the Kurdish opposition's legal activities at home, it came to regard the Kurdish self-defense units and their political wing, the Democratic Union Party in Syria, as a terrorist organization on a par with ISIS.

The official rationale for the Turkish armed forces and the Free Syrian Army to launch joint operations in northern Syria was that military intervention would clear the border territory east of the Euphrates of Kurdish forces, create a "buffer security zone" in Syria, and prepare the ground for the return of refugees. By maintaining its partnership with Turkey within the framework of the Astana format, Russia has shown understanding of Turkish concerns based on the Turkish leaders' assurances that they are committed to the territorial integrity of Syria as the end goal of the political process.

Saudi Arabia's role in the Syrian conflict has undergone significant change as well. The tempestuous developments in the region and the expansion of Iranian influence in Iraq, Lebanon, and Bahrain have convinced Riyadh that Iran is planning to encircle the Islamic holy places with a "Shiite belt" and destabilize the Saudi monarchy. Since the start of the conflict, the Saudis have focused on creating a counterweight to Iran in Syria by consolidating ideologically aligned 
local Islamist forces. By means of funding this part of the armed opposition and imposing Saudi influence over structuring its political wing, Riyadh has played a role in escalating the fighting against government forces.

Once the conflict reached its turning point, the balance of gains and losses was not in favor of the military-political groups backed by Saudi Arabia. The policy to undermine the legitimate regime in Syria from within was in open conflict with the protracted military intervention in Yemen, allegedly undertaken in order to restore the same "constitutional legitimacy." The two-front war was becoming increasingly onerous. With ISIS firmly entrenched in Syria and Iraq, terrorist forces in the southern Arabian Peninsula and in Saudi Arabia itself had a free hand to expand their activities. Hopes for a speedy downfall of the al-Assad regime gave way to a more realistic view, something that took place against the background of deteriorating relations with the U.S. Despite the anti-Iran sentiment, they shared, Saudi Arabia was increasingly displeased with the Trump administration's chaotic and unpredictable policy in the Middle East. There were apprehensions that the U.S. was preparing to withdraw from the region. The Saudis were no longer sure that they would have the support they needed at the critical moment, if Iran decided to take advantage of the U.S. pullout and fill the vacuum.

In parallel, Saudi Arabia was promoting relations with Russia, in spite of their differences over Syria, on the basis of broader joint interests in regional and global politics. Regular contacts, including top-level contacts, were working to achieve mutual understanding on fundamental approaches to a Syrian settlement, including the eradication of the terrorist threat, a speedy start to the Constitutional Committee's operations, and assistance to expand humanitarian aid supplies and the return of refugees.

Russia, as acknowledged by all its opponents, has fundamentally altered the trajectory of the Syrian crisis. By the start of its military campaign in Syria, government forces and various loyal militias were fighting on the outskirts of Damascus and had difficulty containing the enemy's advance on the southern front. That a "Green Islamist International" would come to power in the heart of the Arab world seemed like a foregone conclusion. It was at that moment, in the 
summer of 2015, that President al-Assad famously said that it was necessary to "preserve a useful Syria," meaning the Alawite Corridor in the west the country from Daraa in the south along the seacoast to Latakia in the north, that is, about 30-35 percent of Syrian territory.

Since then, a totally different military reality has taken shape. Damascus has regained control over most of its territory laccording to various estimates, between 68 and 70 percent), while the armed opposition is no longer able to conduct active military operations and retains only some of its enclaves in north-western Syria. The "Arab Caliphate" as a quasi-state terrorist entity has been wiped out along with its military infrastructure. At the same time, numerous obstacles, foreseen and unforeseen, will have to be overcome on the path to a post-conflict settlement. Approximately one-third of Syrian territory is controlled by Turkey (the northern enclave stretching from Hatay Province in Turkey to the western bank of the Euphrates) and the "Syrian Democratic Forces" that were specially trained and equipped by the U.S. (northern and north-eastern areas along the Euphrates). Finally, there is still the problem of Idlib in the west, where the deescalation zone covers parts of the Aleppo and Hama provinces. This territory is dominated by jihadist radical Islamists, who have rallied around the Hay'at Tahrir al-Sham terrorist organization lan alliance of Islamist groupings led by Jabhat Fatah al-Sham, formerly-AlNusra Front also banned in Russia).

\section{BETWEEN GENEVA AND ASTANA: PERIPATETIC INTERNATIONAL MEDIATION}

Three UN Secretary General's Special Envoys for Syria have come and gone during the eight years of the conflict, which was internationalized from the start by the Arab states themselves. There were numerous attempts to find a way forward to a settlement through the joint efforts of the international community, none of which led to the desired result, although, it must be admitted, they made an important contribution to the global practice of conflict settlement and yielded considerable knowledge for the purposes of objectively analyzing the causes of failure. International debates have focused on the mediating role of the United Nations putting forward a number of important questions: whether its special envoy can remain impartial, no matter how skilful 
he is as a negotiator, if the UN Security Council members, to whom he reports, support different sides to the conflict, for which reason he is constantly blamed for being partial by this or that side; whether the success of a mediatory mission depends on the mediator's mandate; and finally, whether a "firm mandate" of the kind that was conferred on the EU High Representative for Bosnia and Herzegovina can be more effective in maintaining the needed pressure on the warring sides.

The Arab League launched a mediatory mission during the first few months of armed clashes, but its efforts proved unsuccessful and were quickly discontinued. The regime and the opposition were hoping to gain an early victory with outside support. Besides the Syrian leaders had every reason to distrust the Arab League, which was under the influence of Saudi Arabia and Qatar. In February 2012, the UN stepped in as an international mediator and continues acting in that role. After the UN Security Council had proved incapable of devising coordinated solutions (the West jointly with the Gulf Arab states were pushing for international legitimation of intervention, but all their proposals were resolutely vetoed by Russia and Chinal, the UN General Assembly asked the then Secretary General to appoint his special envoy for Syria. He chose former Secretary General Kofi Annan, who had considerable peacemaking experience.

A six-point plan devised by the international mediator envisaged an end to military operations, the deployment of a UN observer mission, and a transition to internationally assisted intra-Syrian talks (BAN Ki-Moon, 2012). But this simple and, in theory, correct plan failed to get the Security Council's support and was eventually foiled by the Syrian parties themselves. The UN observers were unable to continue their mission amid unending hostilities, provocations from different sides, and artificial constraints on their movements imposed by the Syrian authorities. In June 2012, Kofi Annan resigned after less than six months on the job.

At the same time, the Annan mission prepared the ground for the first consensus-based international document-the Geneva Communique of June 30, 2012-which later served as the basis for UN Security Council Resolution 2254 (2015) that established the legal framework for the Syrian settlement process. Russia-U.S. interaction played the leading role in this sense, despite the differences between 
the two in the Action Group for Syria. At that time, Russia and the United States managed to reach agreement on the main principles of international support for Syrian efforts to emerge from the crisis. These documents formed the foundation of the mandate issued to the Secretary General's subsequent Special Envoys for Syria, former Algerian Foreign Minister Lakhdar Brahimi and Staffan de Mistura, who had previously headed UN missions in Iraq and Afghanistan.

From the start of UN mediation, the political process ran into problems. The earlier approved international legal documents contained guiding principles for the settlement and a roadmap with timeframes for each of its stages lestablishment of a transitional body with executive powers, drafting of a new constitution, and free elections under international supervision). The most important of the factors that ultimately predetermined the negotiating stalemate in Geneva were the following:

- In the documents on the Syrian settlement process, the UN Security Council was identified as the main and sole implementation mechanism and tool for supporting the Special Envoy. In case of a split in its ranks, the political capital of international mediation would be devalued.

- The U.S.-Russia divide was growing in interpreting the provisions of the Geneva Communique and UN Security Council Resolution 2254 related to the meaning of the transitional period and the sequence of steps. Most of the clashes were over the status and powers of the "transitional governing body" and President alAssad's role and position during that period. Until recently, both the U.S. and the opposition urged his resignation as a precondition for direct intra-Syrian talks. There were no feasible grounds for this farfetched interpretation in the foundational documents.

- There was no support from the Syrian parties whose calculations were based on the assumption of military victory. In September 2016, Russian-American interaction was discontinued, which made it more difficult for the international mediator to compel the Syrians to start negotiations. Intervals between rounds of talks grew lengthier, the escalation of violence continued, and political issues were overshadowed by snowballing humanitarian problems. 
- Protracted debates continued on what should come first-the fight against terrorism or agreements on the parameters of the transitional period, that is, the division of power.

- Divides within the political opposition unfolded, there was persistent internal friction and reshuffling as opposition groups vied for leadership, and inability to enlist the support of field commanders, whose divisions reflected the rivalry between Saudi Arabia, Qatar and Turkey, was obvious.

- A sufficiently strong pressure on the Syrian parties was required. While the Syrian army was having success on the battlefield following Russian intervention and the opposition was increasingly inclined to scale back their inflated demands to more moderate ones, Damascus displayed less and less willingness to make concessions and even veered towards tougher political positions.

- The intra-Syrian and international negotiating venues became increasingly fragmented, which reduced the importance of the Geneva format.

It must be noted that the two major diplomats of international stature armed with an international mandate failed to achieve an effective cessation of hostilities, ensure the unimpeded delivery of humanitarian aid, or bring together the Syrian government and the opposition for direct talks, although they did conduct intensive negotiations in different formats and with various combinations of participants. At the same time, it was largely due to their efforts that the sluggish political process in Geneva was kept going and gradually revealed its weaknesses. In early 2017, it became clear that the military situation had to be stabilized, if the sides were to emerge from the protracted political stalemate. Russia focused on cooperation with Turkey, which had by that time expanded its influence over different organizations of Syrian militants and had shown willingness to cooperate with Russia in Syria. The two were later joined by Iran, which also had a stake in de-escalating the military standoff, and thus the Astana negotiating mechanism, or the Astana format, took shape (Astana, now Nur-Sultan, is the capital of Kazakhstan, where the first meetings were held).

This format, in which Staffan de Mistura was involved, had peculiarities and advantages of its own. It was for the first time that 
Syrian government representatives sat down at the negotiating table with commanders of armed opposition units, whom Damascus had lebeled terrorists. Acting in coordination and on parallel tracks, Russia, Turkey, and Iran provided guarantees that the agreements reached by the sides would be implemented. Turkey was responsible for the "cooperative behavior" of the groups under its influence, while Russia sought to obtain the same response from Damascus. Iran in this complicated setting was supposed to restrain the uncontrolled actions by Hezbollah and Shiite militias. An important result of the regular Astana meetings was the agreements on the four deescalation zones, which for the time being made it possible to reduce the severity of military operations and step up efforts to achieve local ceasefires. The opposition attached much importance to confidencebuilding measures (release of prisoners, prisoner exchanges, etc.), lifting the blockade from a number of populated localities, and delivering humanitarian aid to areas in distress.

The agenda of the intra-Syrian talks in Astana was expanding, eliciting a negative response from the U.S. and leading EU countries, which claimed that the Astana format was encroaching on the political field that UN Security Council Resolution 2254 had set aside for the Geneva process and the mediation of the UN Secretary General's Special Envoy. The relationship between these two formats plagued contacts with Western partners for a long time, the latter expressing distrust of Moscow's peacemaking efforts and suspecting it of attempting to "circumvent" some key provisions of the UN documents and devalue the UN role in the context of the Syrian settlement process. In response, Russia repeatedly explained that the Astana talks and the Russian-Turkish-Iranian summits were aimed at finding compromises and helping the Geneva process and that there was no alternative to settling the Syrian crisis on the basis of international law.

At the same time, the new military realities and changes in the alignment of forces between the regime and the opposition called for certain adjustments in the order and sequence of actions to implement the key provisions of UN Security Council Resolution 2254. While cooperating with the UN Special Envoy, the Syrian government refused to discuss the essentials of establishing, to quote the 
Geneva Communique, "a transitional governing body" capable of exercising "full executive powers." Instead, they suggested various options for a broad-based dialogue in Damascus to form a national unity government, all of which were absolutely unacceptable to the opposition.

This gave rise to the idea of starting a substantive intra-Syrian dialogue by discussing a draft new constitution, the adoption of which appears as one of the central points on the roadmap of the political process. Since late 2017, the Special Envoy has focused on forming a Constitutional Committee. This effort was assisted by Russia, Turkey, and Iran, which were holding regular trilateral summits. The Syrian National Dialogue Congress in Sochi (January 2018) made an important contribution to this effort by adopting a key decision to start drafting a new constitution under UN auspices.

Staffan de Mistura's efforts in this regard, which continued until his resignation in December 2018, showed clearly the full extent of distrust between all sides with political influence. It became obvious that finding points of contact between the interests was a tall order. Russia, for its part, sought to create a broad field of accord on a "balanced and inclusive basis" around the "third list" candidates representing civil society and independent experts (Committee members from the government and the opposition were finally introduced). But Western partners were jealous of Russia's leading role in these efforts. At the same time, steps to finalize the Constitutional Committee's composition were complicated by the position of Damascus that regarded the constitutional process as a "purely sovereign affair" of the Syrian people without any foreign interference, thereby effectively disavowing the UN track.

Simultaneously, a situation that was generally favorable for a gradual transition from the military phase to a political process emerged by early 2019. A rough consensus was forming that the Geneva-2 negotiating paradigm based on the "regime platform" vs the "opposition platform" had outlived its usefulness in the new situation and that there was little promise of any further progress on this track (Centralization and Decentralization, 2018). The new military realities are recognized by the U.S. and Russia's European partners, which are no longer insisting on regime change. Instead, they are empha- 
sizing the need for constitutional reform as soon as possible, to be followed by free elections under UN auspices in conformity with UN Security Council Resolution 2254. The main question is how to bring all components of the political process to their common denominator and whether this is possible in principle against the background of the mounting conflict between Russia and the West.

\section{MAIN COMPONENTS OF THE SYRIAN SETTLEMENT PROCESS}

The basic elements, without which Syria's return to peace and national reconciliation appears impossible, include constitutional and government reform, economic reconstruction, urgent humanitarian aid needed by nearly a half of the population, the return of refugees, a reorganization of the army and security services, UN-supervised elections, and much more.

Post-war Syria's government and political system and its constitutional legitimation are among the key issues at the center of the clash of external interests and internal divisions in Syria. A timetable and procedure for drafting a new constitution is a central requirement for the transition to "inclusive and non-sectarian governance," as contained in UN Security Council Resolution 2254. For all the discrepancies related to the sequence of steps in the transitional period, the international community is evolving a more or less common understanding that the starting point should be the launch of a Syrianled constitutional process, as envisaged by the resolution.

Syrian lawyers and political scientists are advocating two approaches: 1) approving a new constitution, or 2) amending the 2012 law now in effect. Damascus is calling into question the very need for a new constitution in the belief that it is able to deal with all these issues on its own without making substantial concessions. The Syrian opposition, which is riven by divisions on many other issues as well, was basically in favor of a new constitution. But many of its realistically minded members have lately agreed to take as a basis the 2012 constitution, provided there are substantial amendments to it (Constitutional Options for Syria, 2017). In effect, this concerns transitioning from a strictly presidential to a presidential-parliamentary form of governance. The administrative system should be decentralized but the state should retain its unitary 
nature, and the constitution will contain the necessary guarantees of the country's territorial integrity. Any type of a federation is regarded as aimed at partitioning Syria and resolutely rejected by both the regime and the majority of the opposition. This is the little they have in common.

The effort to form a Constitutional Committee has run into serious problems and shown that the drafting of amendments to the current constitution will take a long time. The sticking point is the territorial administrative issue that hinges on the Kurdish factor.

During the war, the Kurds, with support from the U.S. that backed them in the fight against ISIS, managed to create a strong military organization and a system of local governance beyond the reach of Damascus in northern and eastern Syria. The uncertainty regarding the continued U.S. military presence in Syria and the unpredictability of their U.S. ally forced the Kurds to choose between confronting a military threat from Turkey and coming to terms with Damascus. The Kurdish leaders are seeking to retain the de facto autonomous status of their cantons, and to prevent the disbandment of Syrian Democratic Forces units that could assume responsibility for security east of the Euphrates.

The Syrian government's position regarding a special administrative status for the Kurds remains essentially unchanged. According to a statement by Minister of State for National Reconciliation Affairs Ali Haidar, no Syrian province can enjoy preferences that would "differentiate it from other provinces or ethnicities" (Reuters, 2018b). Relevant talks are still in progress on various decentralization formats including decentralization at the level of local communities or the establishment of some asymmetrical territorial administrative system. Law No. 107 on local governments, which is now in effect and acceptable to the opposition, might become a workable basis for discussing the entire gamut of these issues.

Economic revival is another vital aspect of the Syrian settlement process. Of all the conflicts in the region, Syria has suffered the greatest losses in terms of material destruction, casualties, and decline in the quality of human capital. During the war, its GDP has contracted by more than 50 percent, whereas it should have grown by 40 percent under the pre-war economic plan. The budget deficit 
has increased by more than 1,500 percent. The UN estimates the total damage caused by the hostilities at $\$ 250$ billion, whereas the Syrian government has suggested that about $\$ 400$ billion is needed for rebuilding infrastructure alone. According to expert calculations, humanitarian aid requirements are also adding up to the impressive sum of $\$ 20$ billion. More than 70 percent of families are suffering from malnutrition, 80 percent of Syrians have fallen below the poverty line, while life expectancy has been reduced by 20 years.

Under these circumstances, Syria is unable to recover without outside aid. Financial losses and destruction have reached a scale that makes economic reconstruction an insurmountable problem for Syria, or for any other state or even group of states. Conscious of the importance of the economic and humanitarian components of the settlement, Russia has proposed that the U.S., the EU, and other potential donors pool efforts to mobilize resources for economic recovery and the return of refugees.

But a coordinated international policy, even at the UN level, is still lacking, despite the realization that the material damage caused to Syria and its humanitarian plight are unprecedented since the end of the Second World War. The U.S. and EU countries are refusing to finance reconstruction of government-controlled areas in Syria lor more than 70 percent of the most densely populated territory with its infrastructure almost entirely in tatters). Their condition for giving aid is that Syria be transformed as part of a "credible" political process. What is primarily meant is the drafting and approval of a new Syrian constitution to be followed by UN-supervised "free and fair" elections.

The West hopes to use these political terms as a tool to pressure Damascus and its allies. Apart from political considerations, the refusal to cooperate directly with the Syrian government is justified by citing the need to implement administrative reforms and modify property and investment laws. Western experts believe that directing international economic aid through official channels to the country's militarized economy would inevitably strengthen corrupt businesses and local militias in cahoots with the regime (Heydeman, 2017). Still worse, the Syrian leaders, for their part, are also politicizing economic reconstruction issues by declaring that they are not prepared to receive aid from "accomplices of terrorism." Their hope is that a 
number of EU countries might change their approaches if Damascus displays sufficient firmness. This can be seen in President al-Assad's statements to the effect that "the Syrians are able to restore the country on their own" and that "they will not need the West's aid for that" (RBC, 2018). The European countries have indeed split into resolute opponents of cooperation with a "regime that is unamenable to reform" and a conciliatory group that hopes for rapid stabilization or their companies' participation in lucrative projects (Asseburg and Oweis, 2017). It is clear today that developing a coordinated economic rehabilitation project for Syria is a mission for the entire international community, given that the conflict's grave political and humanitarian aftermath has extended far beyond the Middle East region.

The refugee problem is inseparably linked with Syria's reconstruction. Syrian refugees make up no less than one-third of the world's displaced persons. According to UN statistics, nearly a half of Syria's pre-war population has been forced to leave their places of residence $(5.6$ million refugees and 6.6 million internally displaced persons). The biggest number of refugees ( 3.5 million) have fled to Turkey. There are also one million refugees in Lebanon and 650,000 in Jordan (Syria Emergency, 2018). This problem is dragging down neighboring economies and creating serious political and social challenges. In Lebanon, where Syrians make up 20 percent of the population, the refugees have become, to quote Prime Minister Saad Hariri, a "time bomb." Real GDP growth rates have been slowing in Jordan over the last three years and per capita income has not budged since 2012 (Nemeh, 2017).

The Syrian government should have a stake in creating a favorable civic environment for a number of obvious reasons, including the need to restore trust, engage the average business owner, normalize relations with the West, and, last but not least, hold elections (the presidential elections are scheduled for 2021) that would be recognized as legitimate. Russia's appeals and initiatives were instrumental in inducing refugees to return, starting in mid-2018, mainly from Lebanon and Jordan, as well as from Turkey to areas not controlled by the Syrian government. But there are a number of circumstances obstructing a full-scale return of refugees, most importantly the position of the U.S. and the EU, which are of the 
opinion that the internal conditions for a voluntary and safe return are yet to be created. The same view is held by the UN Refugee Agency (UNHCR). According to a Carnegie Endowment study, despite the fact that the majority of refugees are willing to return home, it is unlikely that they will be able to do so in the short term, even if military operations come to an end (Yahya, Kassir and Hariri, 2018).

To create an internal environment incentivizing the beginning of a large-scale repatriation process, a number of preconditions have to be met, as demonstrated by international practice in other conflict zones. These include security, legal guarantees of property rights, the possibility to return to former residences, amnesty for draft evasion, the availability of jobs and social services, and restoration of the healthcare and education systems. This means that much depends on the Syrian government itself, on whether it is able to cope with these major challenges, and if it has the necessary political will.

In the meantime, opposition representatives inclined to come to terms with the government, as well as Western sources, note how inconsistent and contradictory Damascus has been in its efforts related to this sphere of post-conflict reconstruction. Particularly puzzling was the adoption of Law No. 10 of April 2, 2018 (Reuters, 2018al, which enables the Syrian government to confiscate real estate and use it for urban redevelopment without paying compensation to the owners. Syrian citizens regardless of their actual residence are ordered to submit ownership documentation within 30 days, which is basically unrealistic for refugees. It is widely believed that the government-backed law targets the regime's opponents and is intended to resettle loyalists in new development areas in major cities. Although reassuring explanations were offered later and the enforcement of the law was modified, the fact that this law was approved at all did nothing to help restore trust and had negative repercussions.

Implementing other repatriation terms will require real socioeconomic reforms, reorganization of numerous security services and the army, reintegration of combatants into peaceful life, an overhaul of the legal system, and, most importantly, a change in mentality from "winner takes all" to true national reconciliation in which there are "no winners, no losers." 


\section{POST-WAR SYRIA'S PROSPECTS: RUSSIAN INTERESTS}

During the war years, Russia achieved many of the strategic aims it set for the operation in Syria (including through its military diplomacy):

- curtailed efforts of regime change in Syria;

- prevented the coming to power of radical Islamists, the region's subsequent destabilization, and the spill-over of militant Islamism to Russian territory;

- crushed ISIS as a terrorist territorial entity and its military infrastructure. Although the intention to create a joint antiterrorist coalition proposed by Russia failed, Russia and the U.S. fought against ISIS on parallel tracks, albeit separately;

- restored government control over more than two-thirds of Syrian territory;

- consolidated Russia's positions in the Eastern Mediterranean, which has historic significance for the Russian Navy;

- confirmed Russia's status as a world power.

All this raises the question: What's next? What succession of military efforts and diplomatic steps should ensue?

The military-political situation on the ground limits Damascus' opportunities to independently direct further advances of its armed forces. Apart from military and humanitarian problems, liberating Idlib as well as northern and eastern areas by force is contingent on reaching political understanding and some intricate compromises in a broader format rather than between Russia, Turkey, and Iran alone. At this stage, Russia must deploy artful diplomatic maneuvering in order to preserve mutual understanding with its Astana partners without alienating Israel. It will be a difficult challenge to address the legitimate security concerns of Iran and Israel and prevent a clash between them.

We must not discount the possibility of establishing working relations on the post-conflict settlement in Syria with the U.S. outside the channels of military communication that, as both sides admit, are functioning successfully. Contrary to Trump's statements, the U.S. is not going to phase out its military presence in Syria. It does not matter in this case whether the force is reduced and, if so, to what extent, because as the Americans have repeatedly shown, their special forces in eastern Syria will remain under the permanent 
protection of U.S. air power. Keeping a limited contingent in Syria, according to the majority in the U.S. military-political establishment, is seen as a chance to "waive the flag" at multilateral talks on Syria, while keeping an eye on Iran's military communication lines between Iraq, Jordan, and Lebanon.

A new alignment of forces in the conflict symbolizes a certain completion of its military phase and, as logic suggests, creates prerequisites for progress on the political track. The question is what is to be understood by a political solution? Is it a long-term settlement or a mere pretence of one based on superficial changes? A picture of victory is clearly discernible already. This refers in particular to the triumphant mood in Damascus. Allegedly, a military solution has been achieved despite everyone's claims that a military solution was impossible. This means that the future course of the political process should be determined by the winners. Syria's tactics, as outlined by President Bashar al-Assad, consists of working towards reconciliation, but if proved ineffective, using military force to liberate the rest of the country, including from the "U.S. occupation" (Gazdiev, 2018).

This approach is fraught with numerous dangers. As we know from the history of other civil wars, a full victory achieved by one of the sides does not guarantee that peace will return, if the original problems that caused the conflict remain unresolved and the winners continue to face a hostile external environment.

The West has, in effect, recognized that Russia plays a "key role." But it also has been erecting obstacles seeking to make Moscow exert pressure on Damascus, which has always been a much needed, yet difficult, partner for Russia. In this way, responsibility for the final result is being placed on Damascus and its allies. If the U.S. and Europe manage to find points of contact with Russia to develop a common vision for post-war Syria, they will be ready to work together; if not, then any of the current players will be able to act as a spoiler by destabilizing the situation.

It is in Russia's interests to steer the process towards a durable settlement, proceeding from the assumption that the post-war arrangement in Syria cannot be the same as before the war. A new military reality must be consolidated, with the power structure resting on a truly inclusive basis and representing a wide spectrum of national 
patriotic forces, including the political interests of the Sunni majority. Otherwise, the fruits of military success could be lost over time.

Of considerable importance for reaching a long-term settlement is the effort to restore Syria's relations with both-its immediate neighbors (there has been some positive movement in this regard) and the outside world. It is in Russia's interests to work for a settlement that is the result of international consensus, including the international community's recognition of a reformed Syrian regime's legitimacy and Russia's long-term military presence in Syria. If Russia outlines its strategic interests in Syria in a more open and clear manner and signals its readiness for multilateral compromise, it has ample opportunities and military-political influence to secure its interests by non-confrontational means. After so many sacrifices and humanitarian disasters, the ice of mutual antagonism and hatred can only be broken by long-term, patient and, most importantly, uninterrupted multilateral efforts in different combinations.

\section{References}

Al Bunni, A, n.d. A Critical Reading of the New Syrian Constitution (in Arabic). Asseburg, M. and Oweis, K.Y, 2017. Syria's Reconstruction Scramble. German Institute for International and Security Affairs, December. Available from: https://www.swp-berlin.org/en/publication/syrias-reconstruction-scramble/ BAN Ki-Moon, 2012. Letter of UN Secretary General BAN Ki-Moon to Ms. Susan Rise, President of the Security Council. 18 April, New York, p.1.

Centralization and Decentralization, 2018. Centralization and Decentralization in Syria: Concepts and Practices. Fourth Annual Book. Omran Center for Strategic Studies, 15 November, p.13.

Constitutional Options for Syria, 2017. United Nations Economic and Social Commission for Western Asia, National Agenda for the Future of Syria (NAFS) Programme. Available at: http://nafsprogramme.info/library/constitutionaloptions-syria.html

Gazdiev, M., 2018. "Libo u nas est' strana, libo ee net": Asad o budushchem Sirii i podderzhke so storony Rossii ["Either We Have a Country, Or We Do Not": Assad on the Future of Syria and Russia's Assistance], RT, 31 May. Available at: https://russian.rt.com/world/article/518376-intevyu-bashar-asad

Heydeman, S., 2017. Rules for Reconstruction in Syria. Brookings, 24 August. Available from: https://www.brookings.edu/blog/markaz/2017/08/24/rulesfor-reconstruction-in-syria/ 
Iranians Respond, 2018. Iranians respond to the regime: "Leave Syria alone!" Al Jazeera, 2 May. Available at: https://www.aljazeera.com/indepth/opinion/ iranians-respond-regime-leave-syria-180501081025309.html

Nemeh, B., 2017. Jordan's Burden. Carnegie Middle East Center, 21 March. Available at: http://carnegie-mec.org/diwan/68330

RBC, 2018. Asad otkazalsia ot pomoshchi Zapada v vosstanovlenii Sirii' [Assad Refuses Western Assistance in Syria's Reconstruction]. RBC, 24 June. Available at: https://www.rbc.ru/politics/24/06/2018/5b2f7e079a7947 893e238e9d?from=main_rigt

Reuters, 2018a. Assad's property law hits hope of return for Syrians in Germany. Reuters, 14 June. Available from: https://www.reuters.com/ article/us-mideast-crisis-syria-germany-insight/assads-property-lawhits-hope-of-return-for-syrians-in-germany-idUSKBN1JA1V1

Reuters, 2018b. Syrian Minister: Syria's Kurdish-Led Northeast to be Treated Like Rest of Country. Reuters, 4 September. Available at: https://www.reuters. com/article/us-mideast-crisis-syria-kurds/syrias-kurdish-led-northeastto-be-treated-like-rest-of-country-syrian-minister-idUSKCN1LK2FN

Reuters, 2019. U.N. Agency Calls for More Access in Syria to Help Refugees Return. Reuters, 9 March. Available at: https://www.reuters.com/article/ us-mideast-crisis-refugees-grandi/u-n-agency-calls-for-more-access-insyria-to-help-refugees-return-idUSKBN1QQ0JM

Syria Emergency, 2018. The UN Refugee Agency, 19 April. Available at: http:// www.unhcr.org/syria-emergency.html

The Iranian-Saudi Hegemonic Rivalry, 2017. Belfer Center, 25 October. Available at: http://www.belfercenter.org/publication/iranian-saudihegemonic-rivalry

Yahya, M., Kassir, J. and Hariri, K., 2018. Unheard Voices: What Syrian Refugees Need to Return Home. Carnegie Middle East Center, 16 April. Available at: https://carnegie-mec.org/2018/04/16/refugee-attitudestoward-return-to-syria-pub-76061

Valdai, 2014. Zasedanie Mezhdunarodnogo Diskussionnogo Kluba "Valdai”. Valdai International Forum Session, 24 October. Available at: http://kremlin. ru/events/president/news/46860

Wieland, C., 2012. Syria-A Decade of Lost Chances. Repressions and Revolution from Damascus Spring to Arab Spring. The Wall Street Journal, 31 January, p. 29. 


\section{Interview}

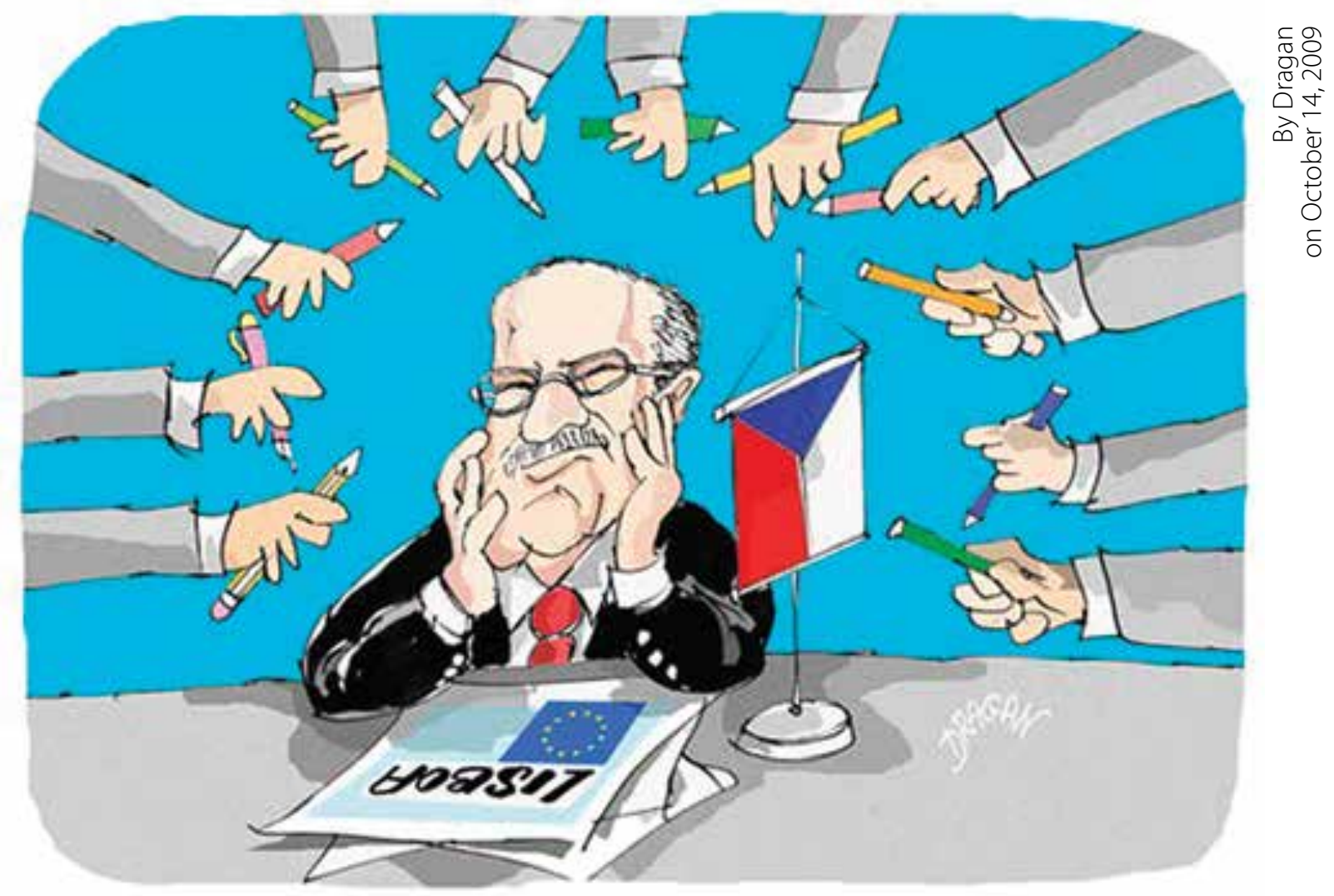

66 Europe is not the doer of history and of international relations, Europe doesn't "behave." We should try to convince the European nation states to start thinking differently, not "continentally." They should accept that Russia is a country with its authentic national interests. 99 


\section{“The EU in its current form is a tragic mistake of the European history"}

Russia in Global Affairs Associate Editor Glenn Diesen talks with former President of the Czech Republic Václav Klaus about the current state of affairs in the EU, populism, green politics, globalization, and other controversial issues of today.

- You are currently writing a book devoted to the 30th anniversary of the fall of communism in your country and the rest of Europe. What are the key themes in the book and the main lessons learnt from the events of 1989 ?

- I have been trying to discuss and analyze the transition from communism to a free society more or less permanently-in an effort to keep the memory of this unique historical process alive. This year's anniversary gives me a new motivation to say something about it. Thirty years since the fall of communism is already a long time, nevertheless, communism is still remembered in our part of the world as if it ended yesterday. In 1948, during the communist putsch in Czechoslovakia, no one mentioned the fact that it was just 30 years since the end of the First World War and the Austro-Hungarian Empire's collapse. Today, on the contrary, we are still discussing the communist heritage.

My book discusses neither communism, nor the events connected with its fall. It is devoted to the discussion of the post-communist

Václav Klaus is a prominent Czech economist and politician, former President of the Czech Republic (2003-2013).

Glenn Diesen, Ph.D., is a professor with the Higher School of Economics, Moscow, Russia and an associate editor of Russia in Global Affairs.

DOI: 10.31278/1810-6374-2019-17-3-198-202 
era. This is much more relevant to our contemporary life than the events of November 1989. My book defends the 1990s, but it is very critical of the years which followed. The frustration the people like me feel now is in some respects similar to that I felt in the last years of communism. We wanted something else than today's European political, economic and social system, than today's European form of integration and the resulting loss of our sovereignty.

- I remember another anniversary, the 10th anniversary of your memorable speech in the European Parliament in 2009. Would it be correct to say that you advocate a European future for the Czech Republic, but you are critical of the direction of the EU's development? What has changed over the past decade and have your views on the EU changed? To what extent is the experience of the 1989 events relevant to the contemporary challenges in Europe?

- This speech of mine was probably the most critical speech ever made in the European Parliament. It is still valid. I wouldn't go there with a different speech now. My views have not changed, the essence of the European integration has. The "European project" has fundamentally moved from integration to unification over the last decades. This shift was mostly done by the Maastricht and the Lisbon Treaties. I consider the EU in its current form a tragic mistake of the European history. We have, however, no way out. For a small country like the Czech Republic, there is no easy Brexit, even though we know that the EU is not able to change itself.

- The political notion that is most frequently used nowadays is "populism." "Populists" are feared and blamed for everything in Europe and in the U.S. What is your perception of this phenomenon? How do you understand "populism?" Do you see it as a real threat to democracy, as liberal critics describe it?

- I am not sure that populism is the most frequent political term, perhaps it is in some circles. I don't like this term and for that reason I never use it. I don't think it is a threat to democracy. Populism has become a political label, a political insult these days. It is used for 
attacking those who disagree with the current European integration and who dare criticize the policies of European and American elites. The real threat to democracy is the caricature of democracy, fashionably called "liberal democracy." It is neither liberal, nor democratic.

- Whom of contemporary statesmen would you describe as likeminded with you? What do you think of such leaders as Donald Trump, Vladimir Putin, Boris Johnson, Emmanuel Macron, Viktor Orbán?

- The five names you selected make up a very mixed and nonhomogeneous group of people. I would say I am in the same boat with Trump, Putin and Orbán-we are all in favor of a nation state (against all kinds of international organizations). These three politicians may be different in many other respects but this one I consider a crucial one. They are not "globalists." Emmanuel Macron is definitely on the other side of the political and ideological barricade, he is a leading globalist of the current era. I am very much afraid of his policies. And Boris Johnson has still to prove that he is able to achieve something.

- Is ideological rivalry over? If we speak about ideology, it seems that the classical ways of thinking that were characteristic of the 19th and 20th centuries are eroding and losing public support. "Peoples' parties" are declining everywhere. What kind of worldview has a future?

- The fight between socialism (or perhaps communism) and capitalism is over. But ideological rivalry continues. The new ideological disputes are no less severe. The political parties and their ideologies have, however, changed. I see as the main danger the currently victorious ideologies of genderism, feminism, multiculturalism, humanrightism, environmentalism, transnationalism, and globalism. I am very critical-including in my book-of them. All of them belong to the left side of politics, but the main allegedly right-of-center political parties are accepting many of their arguments. I am afraid that we-the old-fashioned democrats-are on the losing side. 
- Is globalization in reverse?

- Definitely not. It continues and will go forwards. We shouldn't interpret the disputes between the U.S. and China as deglobalization. Globalization (or better to say the internationalization of economic activities) is a positive phenomenon. The problem is different, it is called globalism, that is, attempts to suppress nation states and deprive them of their sovereignty and independence. Nation states should start defining the rules of globalization. Not everything should be allowed. Total opening up of individual countries is not a rational behavior, we should have clearly defined principles that would guarantee the coherence of individual nation states.

- You are known as a staunch critic of climate change concepts. Meanwhile the "green wave" in politics is being boosted by the apparent worsening of climate in Europe and elsewhere, and increased turbulence in nature. What should people faced with climate change do? And why do you think measures proposed by the Greens are wrong?

- I don't think the weather in Europe is "constantly worsening." I am not aware of anything like that, the data do not show it. To say that the weather is worsening is an empty phrase propagated by all kinds of Greens (not just by Green political parties but by the Greens in all political parties). The current climate in Europe is not a problem. The problem is our fighting the climate, a hopeless, democracy-suppressing and economy-undermining behavior.

- Russia's grievances with Europe after the fall of communism have focused on the absence of post-Cold War settlement accommodating Russia on the continent. How do you see the future of the relations between Russia and Europe? Does the nascent strategic partnership between Russia and China offer opportunities and/or challenges for Europe?

- The question has three aspects:

First, I don't believe it should be called "Russia's grievances." Any plans for a post-Cold War European "settlement" have been rather 
exercises in "wishful thinking" than real projects. They have never been realistic and meaningful concepts. We saw it as a continuation of Gorbachev's naive concept of a "Common European Home." No one in Western or Central Europe was interested in it at that time. That said, I do not imply that I accept the current very dangerous and unfair demonization of Russia by the West. This policy, or perhaps this ersatz of policy, threatens to become a problem.

Second, the passive extrapolation of current trends and tendencies in relations between Europe and Russia suggests new Cold War era outcomes. This is something which must be avoided.

I have a problem using the term 'Europe' in our discussions. Europe is not the doer of history and of international relations, Europe doesn't "behave." We should try to convince the European nation states to start thinking differently, not "continentally." They should accept that Russia is a country with its authentic national interests.

And, third, the strategic partnership between Russia and China is only a hypothetical project of the future. I don't see it now, not even in its "nascent" form. It seems to me that China is not interested in it. China wants a G2 arrangement with the U.S., not a G3 version (including Russia). 


\section{Review}

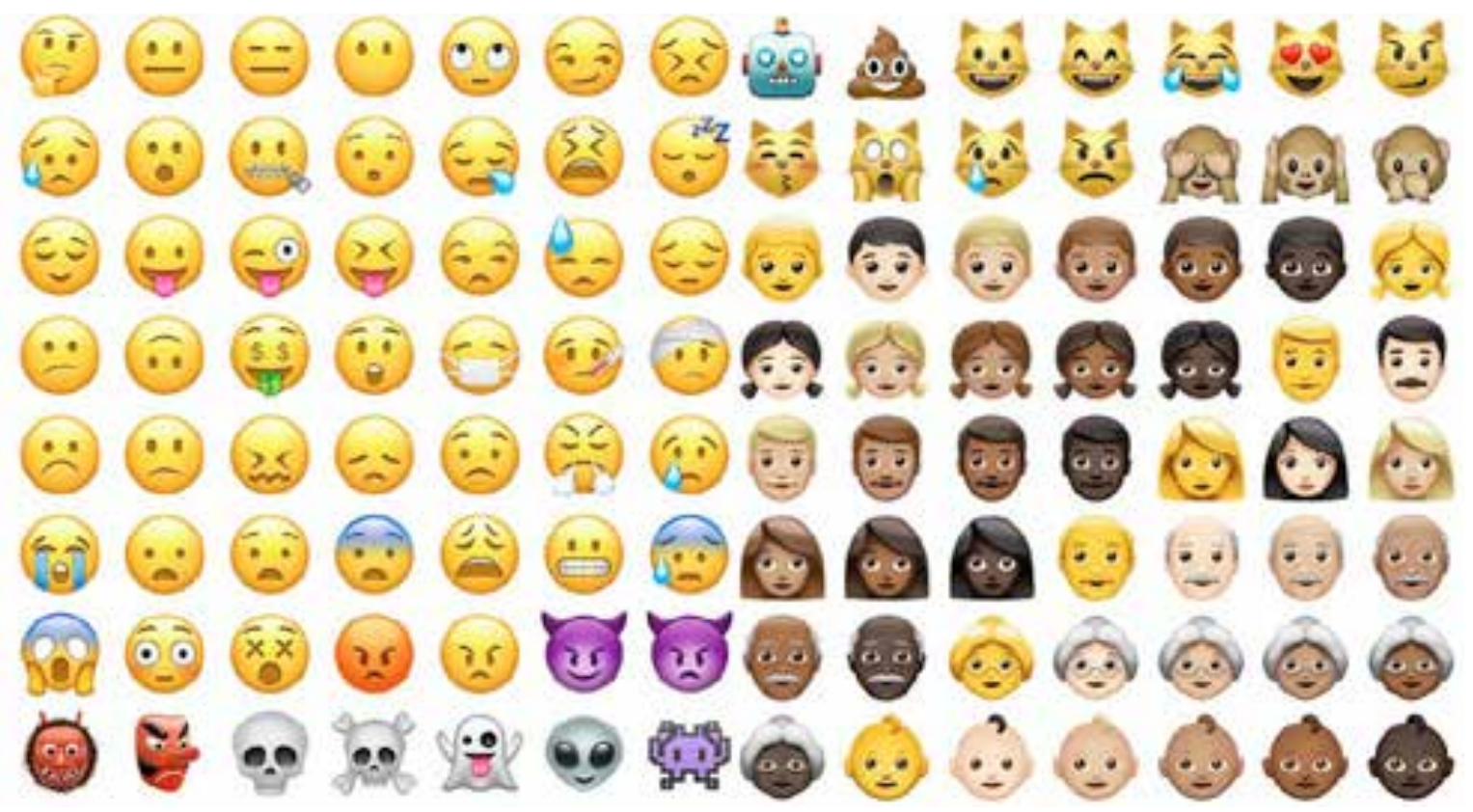

66 History, the end of which Fukuyama predicted some time ago with a big commercial success, has simply been negated by suggesting that interaction mechanisms concerning "identity" do not change over centuries. 99 


\title{
Admonishing the Doubting Flock
}

Review of Francis Fukuyama's Book "Identity: The Demand for Dignity and the Politics of Resentment"

\author{
Alexei I. Miller
}

Identity. The demand for dignity and the politics of resentment. New York: Farrar, Straus and Giroux, 2018

\begin{abstract}
Almost twenty years ago Rogers Brubaker and Frederick Cooper published an article that became a classic (Brubaker R., Cooper F. Beyond "Identity" // Theory and Society. \#1 (2000). P. 1-47). Here is what the authors said at the beginning of the article: "The argument of this article is

\footnotetext{
Alexei I. Miller

European University at Saint-Petersburg, Russia

Department of History

Professor;

European University at Saint-Petersburg. Russia

Center for the Study of Cultural Memory and Symbolic Politics

Academic Director
}

that the social sciences and humanities have surrendered to the word 'identity'; that this has both intellectual and political costs; and that we can do better. 'Identity', we argue, tends to mean too much (when understood in a strong sense), too little (when understood in a weak sense), or nothing at all (because of its sheer ambiguity)...

"Soff' constructivism allows putative 'identities' to proliferate. But as they proliferate, the term loses its analytical

ResearcherID: Z-1451-2019

Scopus AuthorID: 56321369000

Тел: +7 (812) 386-7634

E-mail: amiller@eu.spb.ru

Address: European University at St. Petersburg, 6/1A Gagarinskaya Street, 191187 St. Petersburg, Russia. 
purchase. If identity is everywhere, it is nowhere... 'Identity' is a key term in the vernacular idiom of contemporary politics, and social analysis must take account of this fact. But this does not require us to use 'identity' as a category of analysis or to conceptualize 'identities' as something that all people have, seek, construct, and negotiate. Conceptualizing all affinities and affiliations, all forms of belonging, all experiences of commonality, connectedness, and cohesion, all self-understanding and selfidentification in the idiom of 'identity' saddles us with a blunt, flat, undifferentiated vocabulary."

There are several reasons why this quote is important for evaluating Francis Fukuyama's book "Identity: The Demand for Dignity and the Politics of Resentment." First of all, it clearly shows that "identity politics" was quite trendy at the beginning of the century, and the notion of 'identity' was so much abused in social sciences that Brubaker and Cooper had to remind everyone that it did not explain much but rather needed some clarification itself.

Secondly, having found out that this article, its admonitions and questions were ignored in Fukuyama's book, we can say with confidence that this is not a scholarly text but a piece of writing intended for a broad audience. Its genre can be compared in the Russian context with
Yekaterina Shulman's or Valery Solovei's essays. For this reason we shall give up the idea of writing a critical scholarly review of this book as inappropriate.

In a nutshell, Fukuyama's argument is as follows:

"Individuals throughout human history have found themselves at odds with their societies. But only in modern times has the view taken hold that the authentic inner self is intrinsically valuable, and the outer society systematically wrong and unfair in its valuation of the former. It is not the inner self that has to be made to conform to society's rules, but society itself that needs to change.

“... what was to become the modern concept of identity emerged only as societies started to modernize a few hundred years ago. While it originated in Europe, it has subsequently spread and taken root in virtually all societies around the globe.

“... The modern concept of identity unites three different phenomena. The first is thymos, a universal aspect of human personality that craves recognition. The second is the distinction between the inner and the outer self, and the raising of the moral valuation of the inner self over outer society. This emerged only in early modern Europe. The third is an evolving concept of dignity, in which recognition is due not just to a 
narrow class of people, but to everyone. The broadening and universalization of dignity turns the private quest for self into a political project. In Western political thought, this shift took place in the generation after Rousseau, through the philosophers Immanuel Kant and particularly Georg Wilhelm Friedrich Hegel.

“...Contemporary identity politics is driven by the quest for equal recognition by groups that have been marginalized by their societies. But that desire for equal recognition can easily slide over into a demand for recognition of the group's superiority. This is a large part of the story of nationalism and national identity...

"...The impulses evident in the early stages of the Arab Spring and in the color revolutions point to what is the moral core of modern liberal democracy. Such regimes are based on the twin principles of freedom and equality.

“...Modern liberal democracies promise and largely deliver a minimal degree of equal respect..."

Fukuyama backs his theses with a variety of examples from different parts of the world, the essence of which is usually stated in one or two phrases, thus clearly indicating the author's superficial understanding of the processes unfolding there. It is important, though, that all of them should cite examples of identity politics. Here is a typical example of such "analysis": "A person living in Barcelona who suddenly realizes her real identity is Catalan rather than Spanish is simply excavating a lower layer of social identity that has been laid down beneath the one nearer to the surface." (Trust me; this is all the author can say on the matter!)

History is of no importance. In other words, it is seen as a "completely clear" and purely Western-centric oneway movement: "While it originated in Europe, it has subsequently spread and taken root in virtually all societies around the globe". The concept of modernization, with its shameless Western centrism and triumphalism of liberal democracy, has now been complemented with "identity history," which Fukuyama views as a function of modernization. Some fifty years ago, even the advocates of the theory of modernization had to admit that it was not working in its original form because it failed to take into account the sociocultural peculiarities of different societies. But for Fukuyama one explanation fits all: "This is what drove Americans to protest during the civil rights movement, South Africans to stand up against apartheid, Mohamed Bouazizi to immolate himself, and other protesters to risk their lives in Yangon, Burma, or in the Maidan or 
Tahrir Square, or in countless other confrontations over the centuries."

History, the end of which Fukuyama predicted some time ago with a big commercial success, has simply been negated by suggesting that interaction mechanisms concerning "identity" do not change over centuries. "Hans's personal story was characterized by the nineteenth-century social theorist Ferdinand Tönnies as the shift from Gemeinschaft to Gesellschaft, or from (village) community to (urban) society. It was experienced by millions of Europeans during the nineteenth century and is now happening in rapidly industrializing societies such as China and Vietnam." Let's forget the fact that the Gemeinschaft concept is quite applicable to Greek polis and even medieval cities. But can one really say that the movement of people from rural areas to cities in the contemporary world with its television and the Internet proceeds in the same way it did in 19th century Europe when it went through the process of alphabetization (eradication of illiteracy)?

It is no wonder that to Fukuyama the main authority among the researchers of nationalism is Ernest Gellner, an extremely schematic radical modernist who sincerely believed that there was correct civic nationalism in Western countries and incorrect, ethnic nationalism in other parts of the world. Fukuyama himself seems to believe this. In fact, the history of ideas is portrayed in his book in a very old-fashioned manner as a story telling about how a certain idea traveled through centuries from one bright mind to another, even brighter one, and makes a meaningful observation that Luther, Rousseau, Kant, and Hegel understood dignity differently.

The book should be judged by the law of the genre, that is, by trying to understand what exactly the politically motivated public intellectual wants to tell his readers and why. And what kind of readers? The text is addressed to people who believe in liberal democracy but who have become hesitant under the impression of recent events. Fukuyama considers many examples where things do not go the way they should. In his opinion, the reason for this is that the principles of liberal democracy have been buried in oblivion or because backward tribes and "populists" have failed to understand these principles. The most painful and difficult questions about how well liberal democracy has adapted to the new conditions and where it has lost the ability for critical reflection have been left out.

When giving his political recommendations in the end, Fukuyama has to admit that they 
cannot be implemented in practice. So, We will not escape from thinking about his conclusion sounds like admonition ourselves and our society in identity to the flock that is living through hard terms. But we need to remember that times: the identities dwelling deep inside us

"We can imagine better places to be are neither fixed nor necessarily given in, which take account of our societies' to us by our accidents of birth. Identity increasing diversity, yet present a vision can be used to divide, but it can and has for how that diversity will still serve also been used to integrate. That in the common ends and support rather end will be the remedy for the populist than undermine liberal democracy. politics of the present."

Identity is the theme that underlies As is often the case with sermons, many political phenomena today, from this conclusion sounds quite trivial new populist nationalist movements, to and absolutely "unscientific," but Islamist fighters, to the controversies nothing can prevent those wishing to taking place on university campuses. believe in it. 